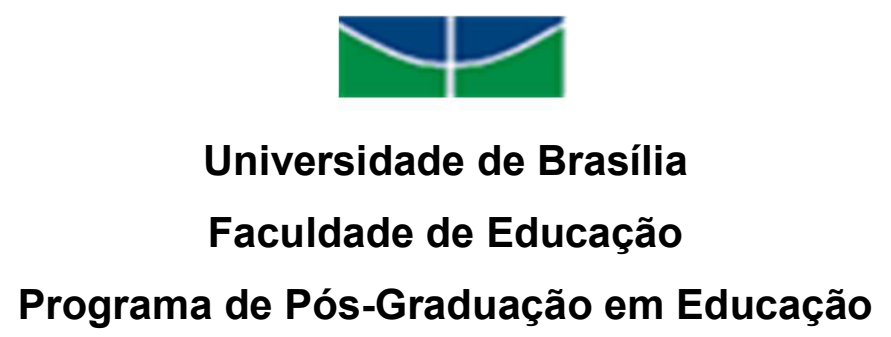

ESTRATÉGIAS DE ESTUDANTES CONCLUINTES DA EDUCAÇÃO BÁSICA NA RESOLUÇÃO DE PROBLEMAS MATEMÁTICOS

Juliana Campos Sabino de Souza

BRASÍLIA 


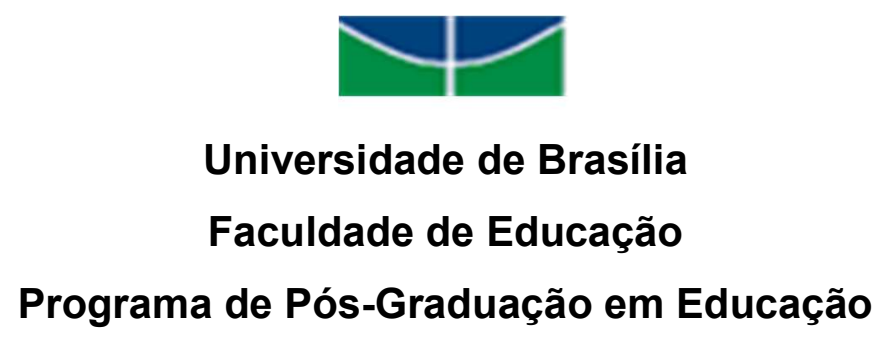

Programa de Pós-Graduação em Educação

\title{
ESTRATÉGIAS DE ESTUDANTES CONCLUINTES DA EDUCAÇÃO BÁSICA NA RESOLUÇÃO DE PROBLEMAS MATEMÁTICOS
}

\author{
Juliana Campos Sabino de Souza
}

Dissertação apresentada ao Programa de Pósgraduação em Educação da Faculdade de Educação, Universidade de Brasília PPGE/FE/UnB, sob orientação do Professor Doutor Cleyton Hércules Gontijo, como requisito parcial à obtenção do título de Mestre em Educação.

BRASÍLIA 
Ficha catalográfica elaborada automaticamente, com os dados fornecidos pelo(a) autor(a)

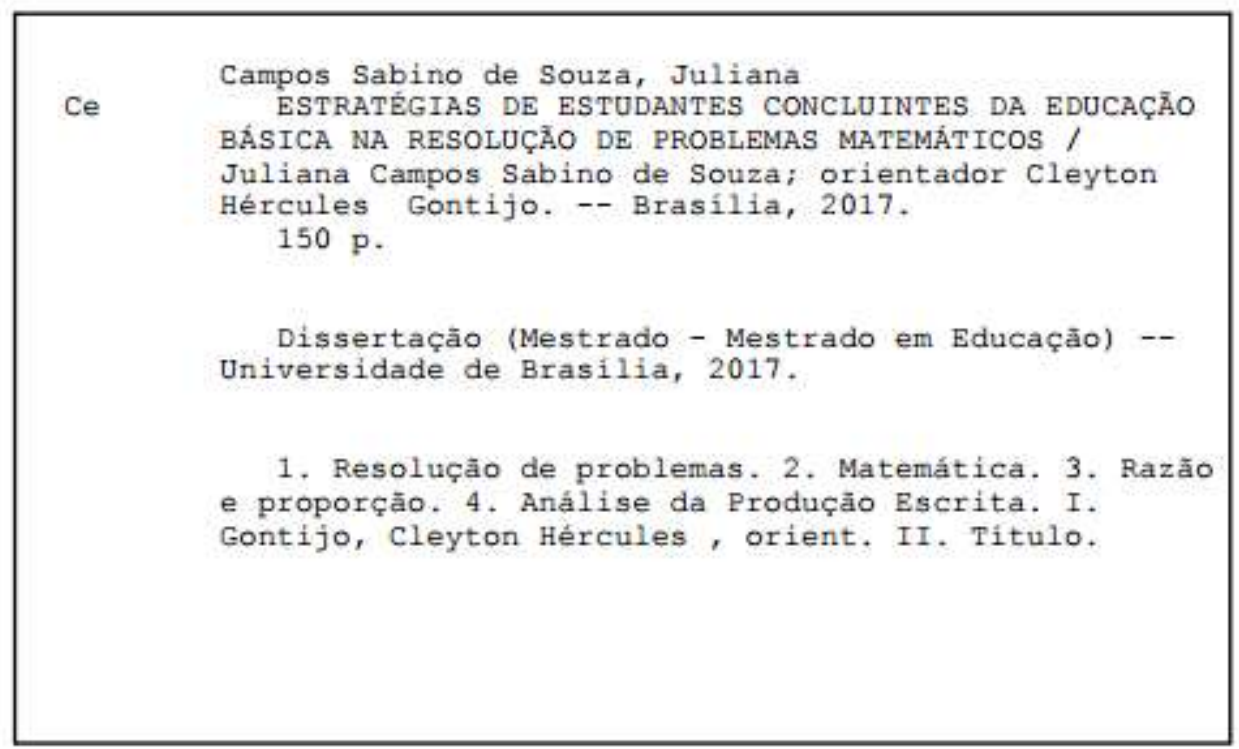




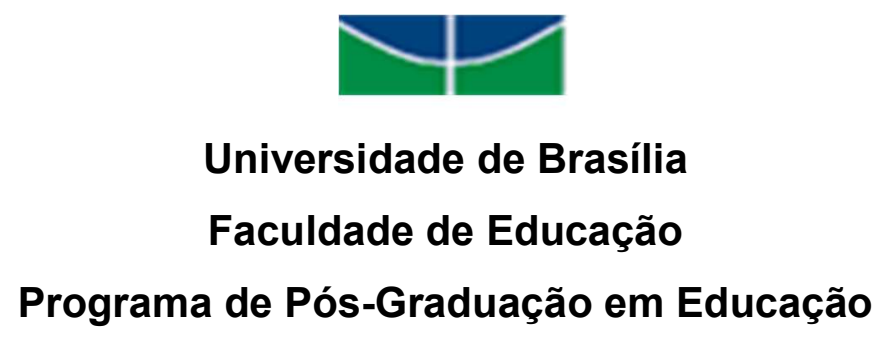

DISSERTAÇÃO DE MESTRADO

ESTRATÉGIAS DE ESTUDANTES CONCLUINTES DA EDUCAÇÃO BÁSICA NA RESOLUÇÃO DE PROBLEMAS MATEMÁTICOS

Juliana Campos Sabino de Souza

COMISSÃO EXAMINADORA

Prof. Dr. Cleyton Hércules Gontijo Orientador - FE/UnB

Profa. Dra. Erondina Barbosa da Silva Membro - UCB / SEEDF

Profa. Dra. Regina da Silva Pina Neves

Membro - MAT/UnB

Prof. Dr. Cristiano Alberto Muniz

Suplente - MTC/FE

BRASÍLIA 
"O que para alguns é um problema, para outros é um exercício e para alguns outros uma distração". 
Aos meus pais, irmã e esposo. 


\section{AGRADECIMENTOS}

Ao professor Cleyton Hércules Gontijo, por ter paciência e me orientar em meus dilemas...

Ao meu esposo, Mateus Gianni, por me dar suporte em todos os momentos e me estimular nos momentos de cansaço e desmotivação sendo sempre meu porto seguro.

À minha família, Isaú, Maria do Carmo e Regina, por estarem sempre comigo me incentivando no meu processo de desenvolvimento pessoal desde sempre.

Aos meus amigos que, direta ou indiretamente, participaram desse momento de realização pessoal.

A Deus... 


\section{Resumo}

Este trabalho possuiu por propósito analisar as estratégias utilizadas por estudantes concluintes da educação básica de uma escola pública quando postos frente a diferentes tipos de questões, as quais estavam classificados como exercícios, problemas rotineiros e não rotineiros, relacionadas aos conceitos de matemáticos de razão e proporção. Assim, buscou-se a partir de uma intersecção entre as literaturas da área de educação matemática encontrar meios de identificar as estratégias utilizadas pelos estudantes, tanto individualmente quanto em grupo, verificando como esses indivíduos lidam com atividades dessas naturezas. Trata-se de uma proposta de estudo de caso, de método qualitativo, que por meio de diferentes instrumentos, como inventários, coleta de protocolos e observação, agrupar o maior número de informações. Pode-se observar que grande parte dos participantes demonstraram conhecer o algoritmo geralmente relacionado a regra de 3 simples (propriedade fundamental das proporções) obtendo sucesso na resolução dos exercícios, entretanto, diante dos problemas rotineiros e não rotineiros, obteve-se menor quantitativo de resultados corretos. Dessa forma, quanto maior a necessidade de interpretação e modelagem para se resolver o problema, menor o índice de acerto. Para a resolução dos problemas, os participantes, em sua maioria, optaram por realizar principalmente multiplicações e divisões ou outros procedimentos para resolvê-los, sendo que poucos utilizaram a regra de 3. Destaca-se também algumas dificuldades demonstradas pelos participantes, como interpretar os problemas, relacionar as grandezas e modelar o problema para a resolução. Esta pesquisa também evidenciou a desmotivação do alunado concluinte do ensino médio de uma escola pública do Distrito Federal, bem como a fragilidade conceitual de elementos básicos relacionados a razão e proporção.

Palavras-Chave: Matemática. Resolução de problemas. Razão e proporção. 


\begin{abstract}
The purpose of this dissertation was the analyze of the strategies used by students who were finishing the basic education of a public school when they face different types of questions, which were classified as exercises, routine and non-routine problems related to the concepts of ratio and mathematicians proportion. Thus, it was sought from an intersection between the literature of the area of Mathematics education to find ways to identify the strategies used by the students, individually and in groups, verifying how these individuals deal with activities of this nature. It is a proposal case study of qualitative method used different instruments, like inventories, collection of protocol and observation to group the greater number of information as possible. It is possible to observe that most of the participants really know the algorithm generally related to rule of 3 simple (fundamental property of the proportions) obtaining success in the resolution of the exercises, however, by facing routine and non-routine problems, a lower number of correct results were obtained. This way, as long as they have to intepretat and model to resolve the problem, their results are low. To solve the problems, the majority of the participants have chosen to perform mainly multiplication and division or other procedures to solve them and just a few students used the rule of 3 . It is also important to highlight some difficulties showed by the participants, such as interpreting the problems, relating the proportional quantities and modeling the problem for resolution. This research also has evidenced the demotivation of the high school graduate student of a public school in the Federal District, as well as the conceptual fragility of basic elements related to reason and proportion.
\end{abstract}

Keywords: Mathematics. Troubleshooting. Ratio and proportion. 


\section{LISTA DE ILUSTRAÇÕES}

Figura 1: Relação entre processos matemáticos (na coluna) e habilidades matemáticas fundamentais (na linha) ................................................................ 33

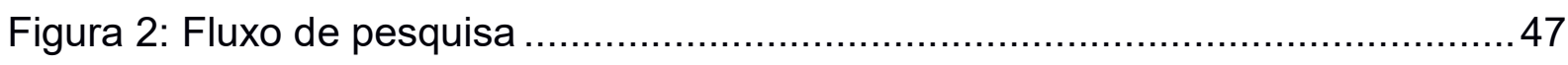

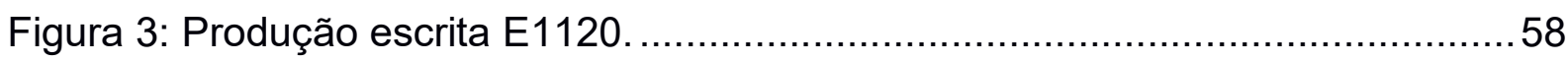

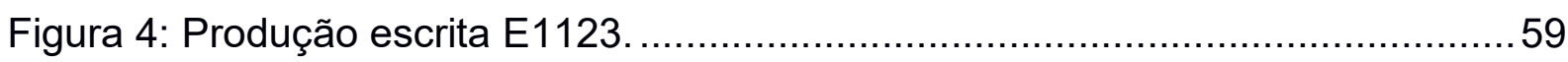

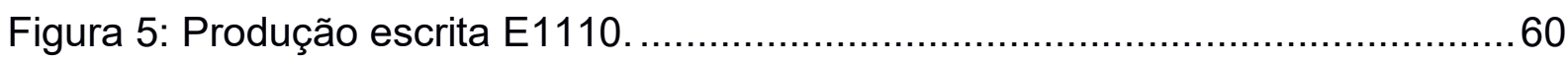

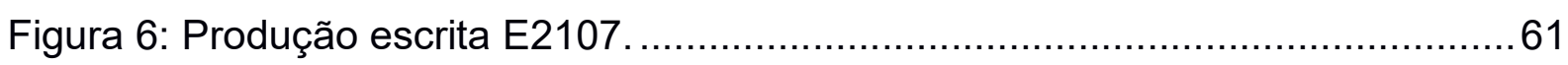

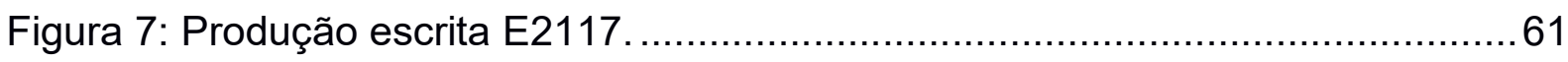

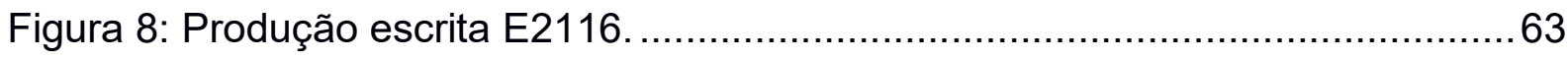

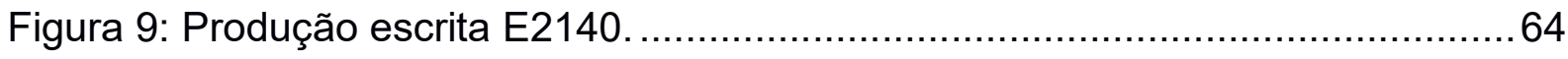

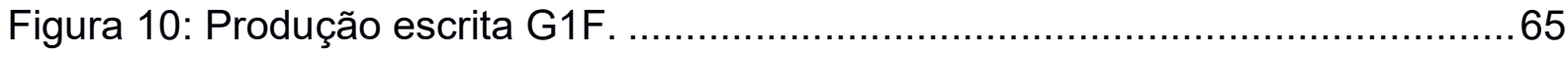

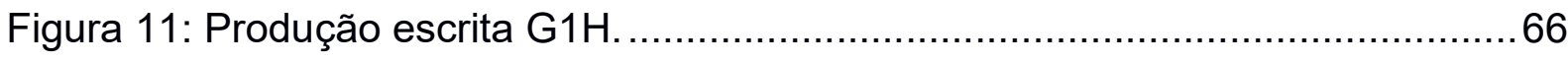

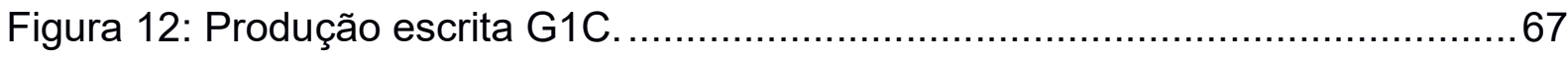

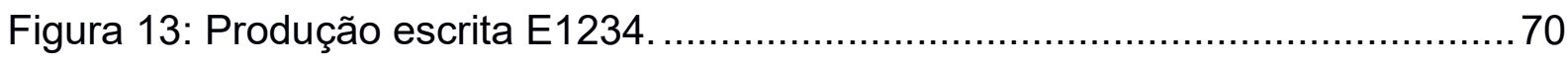

Figura 14: Produção escrita E1224 .............................................................. 71

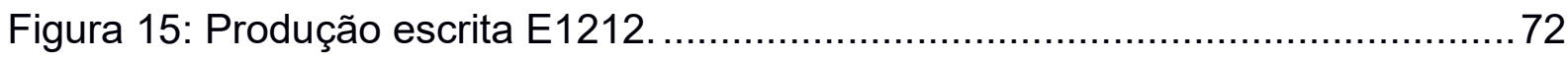

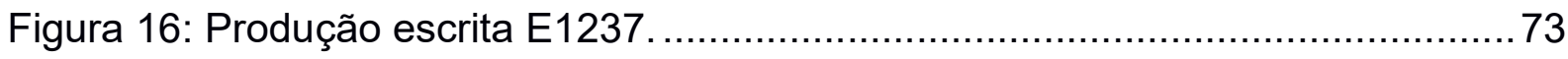

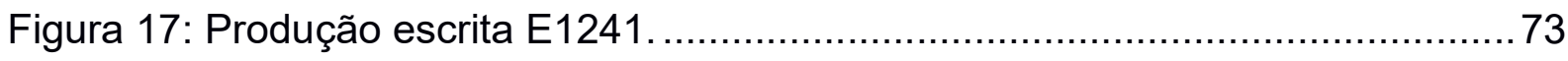

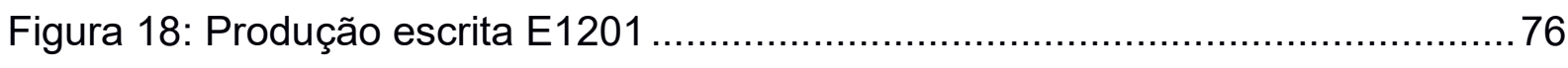

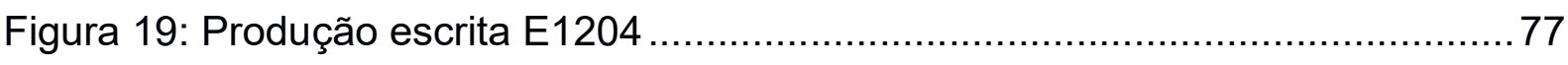

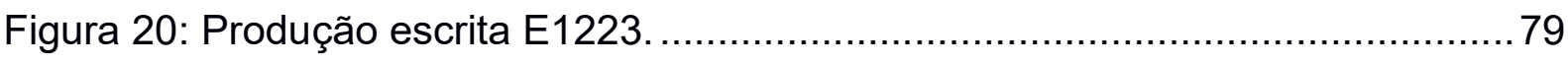

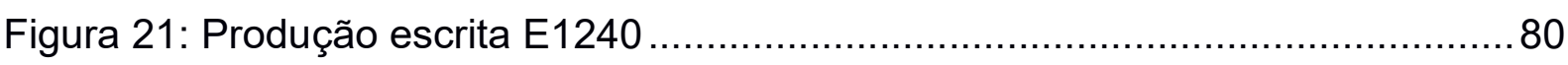

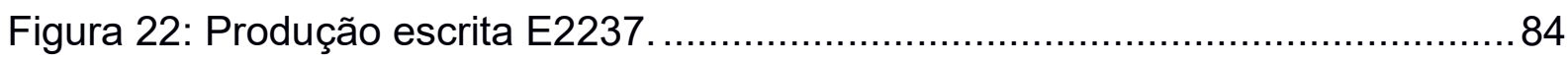

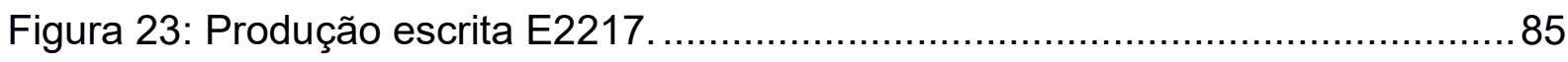

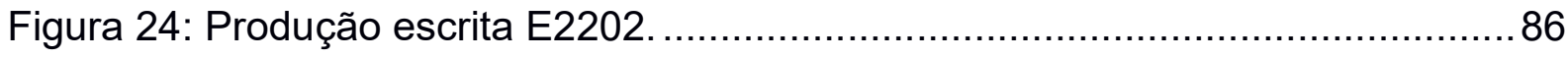

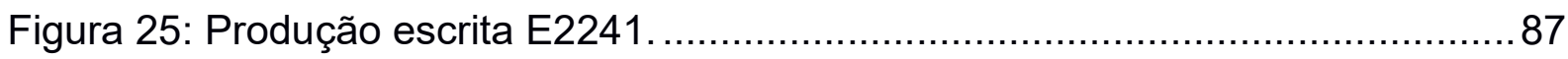




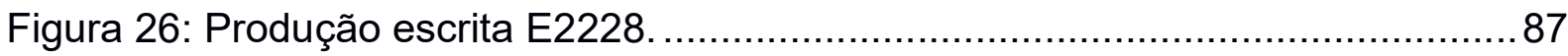

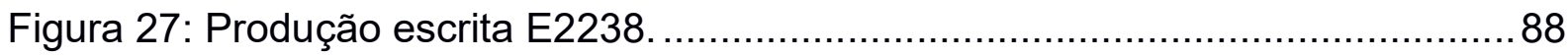

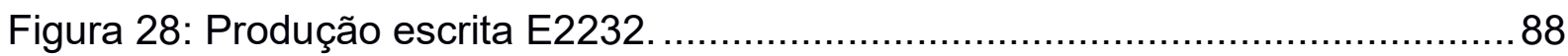

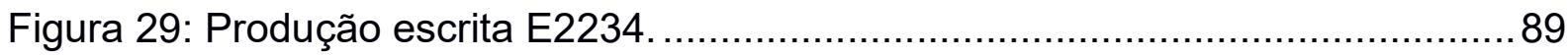

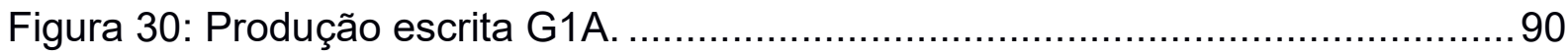

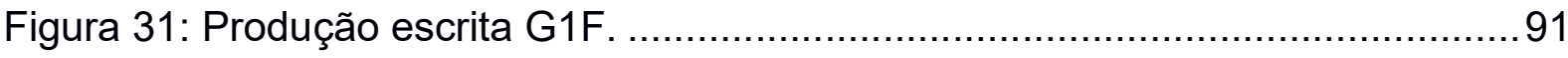

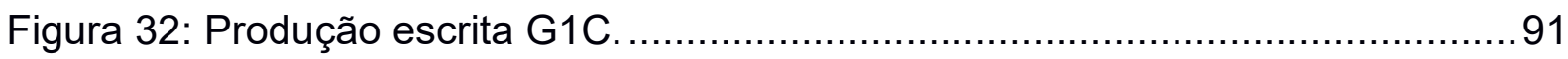

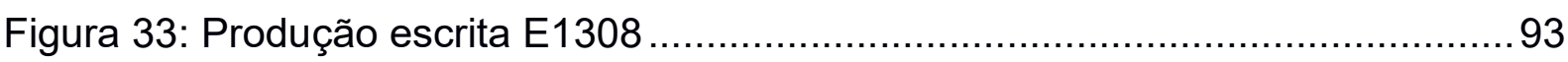

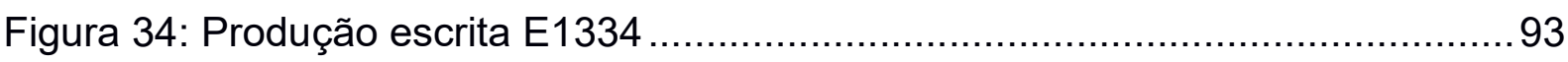

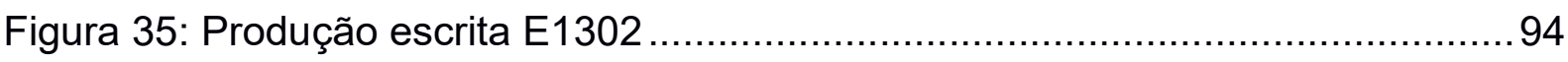

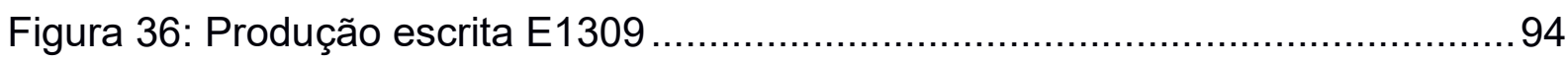

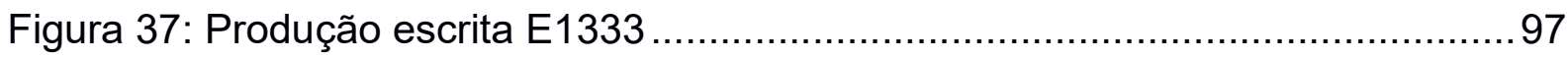

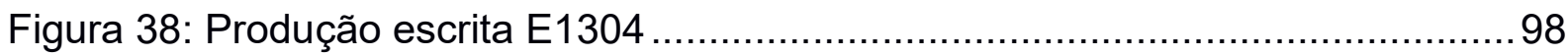

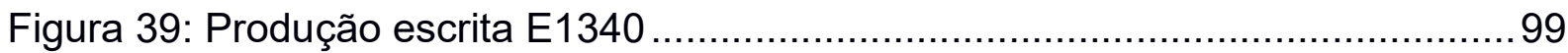

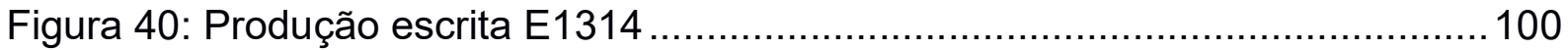

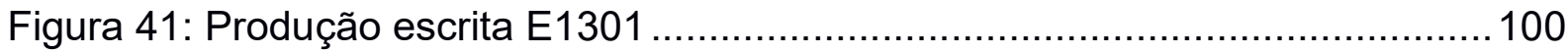

Figura 42: Produção escrita E1320 ................................................................100

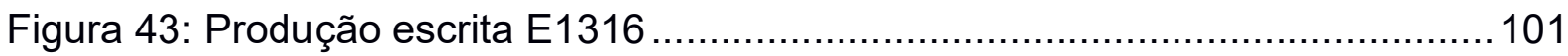

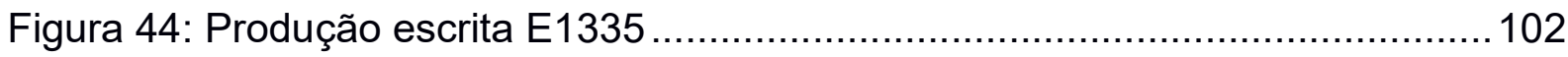

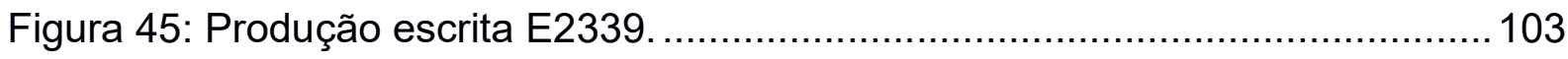

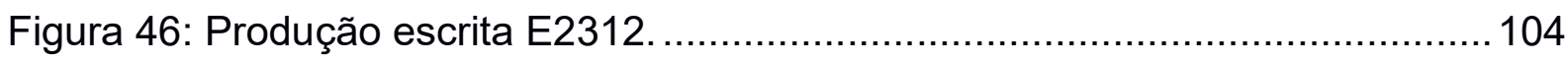

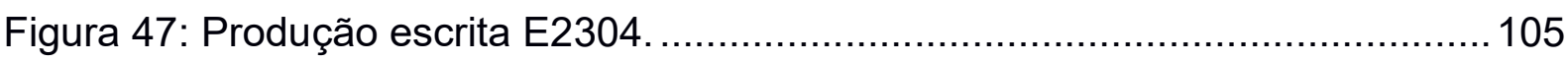

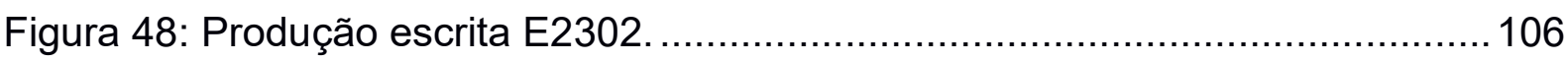

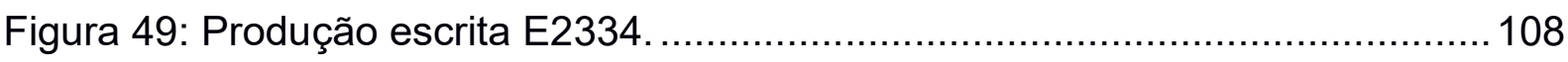

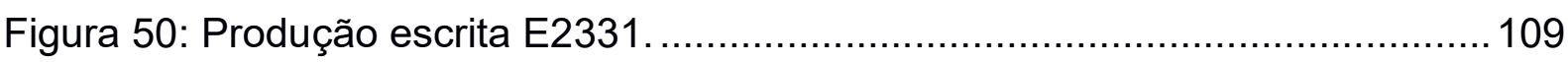

Figura 51: Produção escrita E2342 …………………................................ 110

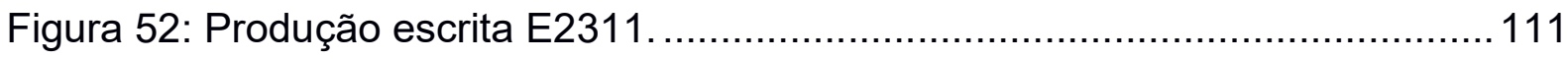




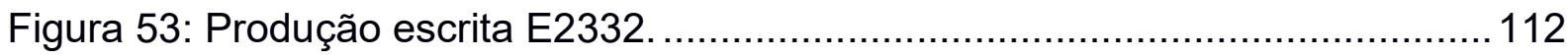

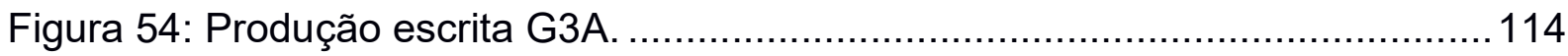

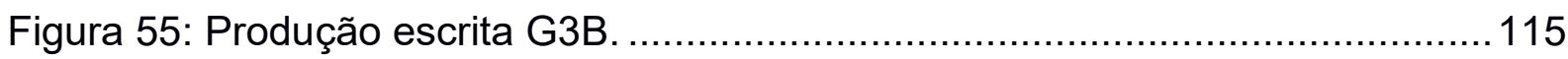

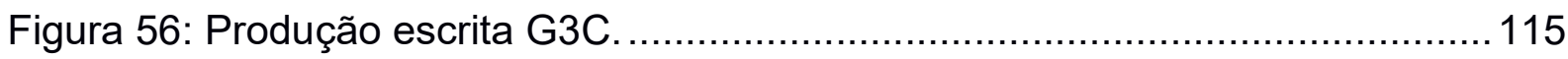

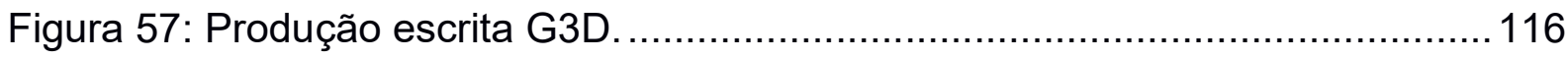

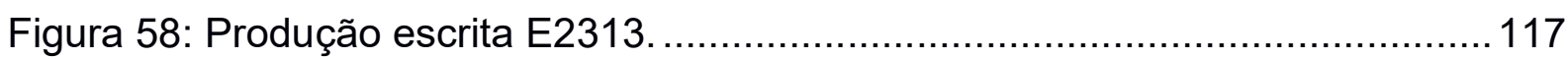

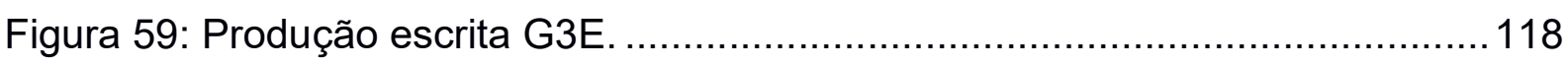

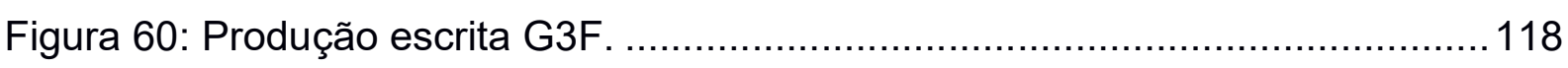

Figura 61: Produção escrita G3G...............................................................119

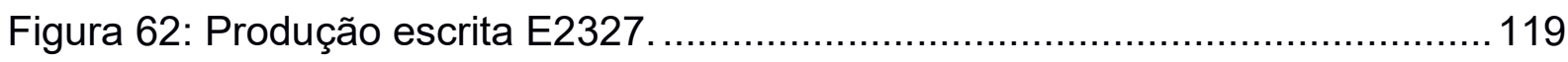

Figura 63: Produção escrita G3H............................................................... 120

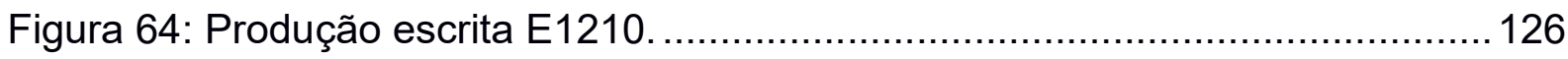

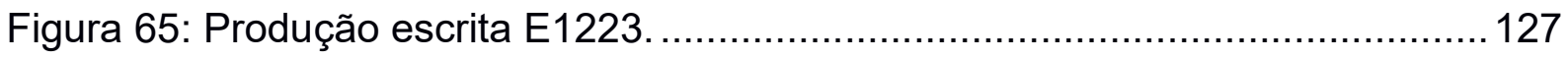

Figura 66: Produção escrita encontrada no relato do observador do grupo H........ 128

Figura 67: Produção escrita encontrada no inventário do participante 29 ............... 128

Figura 68: Produção escrita encontrada no inventário do participante 27 .............. 129

Figura 69: Produção escrita encontrada no inventário do participante 35............... 129

Figura 70: Produção escrita encontrada no inventário do participante 09............... 129

Figura 71: Produção escrita encontrada no relato do observador do grupo C....... 130

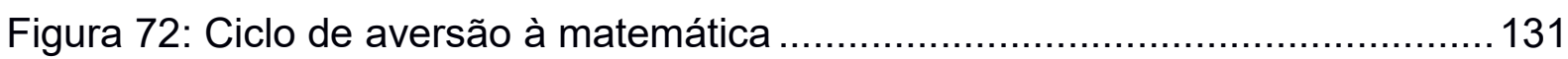

Figura 73: Produção escrita encontrada no relato do observador do grupo F. .......132

Figura 74: Produção escrita encontrada no inventário do participante $40 \ldots \ldots \ldots \ldots \ldots . . .132$ 


\section{LISTA DE TABELAS}

Tabela 1: Nível dos alunos em matemática da escola participante da pesquisa ......46

Tabela 2: Quantitativo de questões resolvidas pelos participantes da pesquisa.......52

Tabela 3: Desempenho dos participantes nos exercícios ................................. 57

Tabela 4: Desempenho dos participantes nos problemas rotineiros ......................57

Tabela 5: Desempenho dos participantes nos problemas não rotineiros .................58

Tabela 6: Erros relacionados as 4 operações fundamentais da aritmética ...............81

Tabela 7: Resoluções utilizando regra de 3 ................................................ 122

Tabela 8: Autodefinição das habilidades em matemática dos participantes ...........125

Tabela 9: Autodefinição da motivação em matemática dos participantes ...............126 


\section{LISTA DE SIGLAS E ABREVIATURAS}

ANA - Avaliação Nacional da Alfabetização

ANEB - Avaliação Nacional da Educação Básica

ANRESC - Avaliação Nacional do Rendimento Escolar

DF - Distrito Federal

ECT - Empresa de Correios e Telégrafos

FIC - Formação Inicial e Continuada

FE - Faculdade de Educação

IFB - Instituto Federal de Educação, Ciência e Tecnologia de Brasília INEP - Instituto Nacional de Estudos e Pesquisas Anísio Teixeira OECD - Organization for Economic Cooperation and Development PA - Progressão Aritmética PCN - PARÂMETROS CURRICULARES NACIONAIS

PISA - Programme for International Student Assessment PPGE - Programa de Pós-Graduação em Educação OBMEP - Olimpíada Brasileira de Matemática das Escolas Públicas SAEB - Sistema de Avaliação da Educação Básica UnB - Universidade de Brasília 


\section{SUMÁRIO}

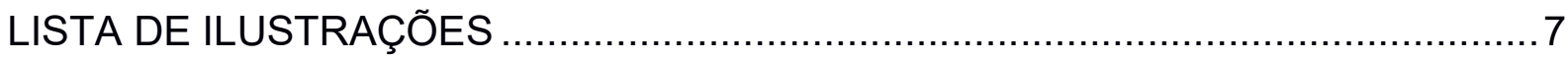

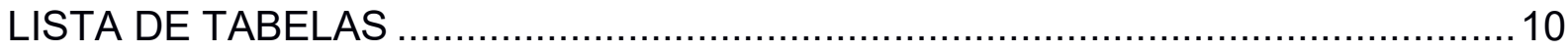

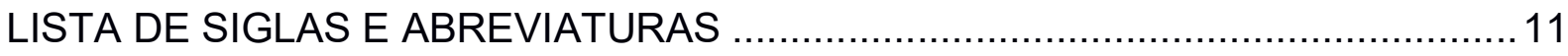

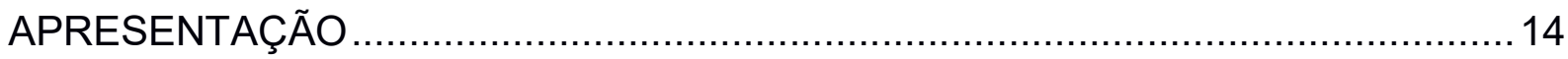

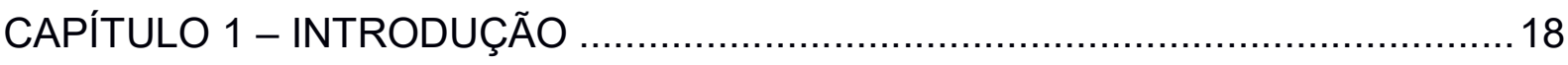

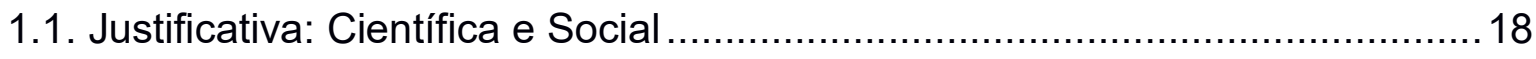

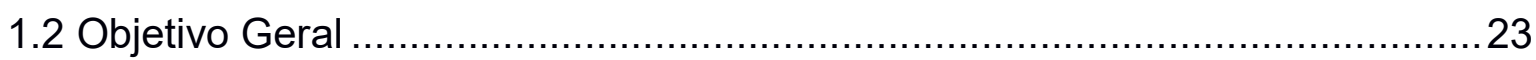

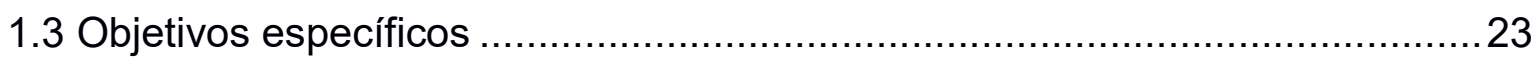

CAPÍTULO 2 - DIALOGANDO COM OS AUTORES .................................... 24

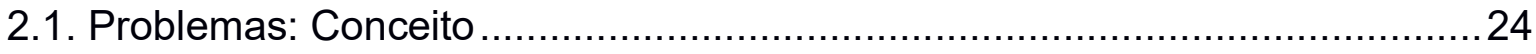

2.2.Tipos de Problemas: rotineiros e não rotineiros ..................................... 26

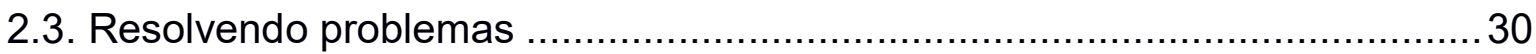

2.4. Análise da produção escrita .............................................................. 35

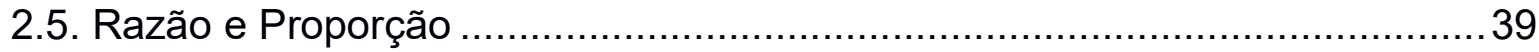

CAPÍTULO 3 - PERCURSO METODOLÓGICO ...........................................43

3.1. Fundamentos Teórico-Metodológicos ............................................... 43

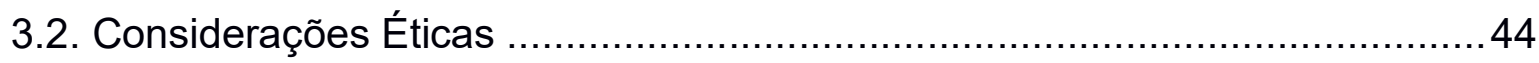

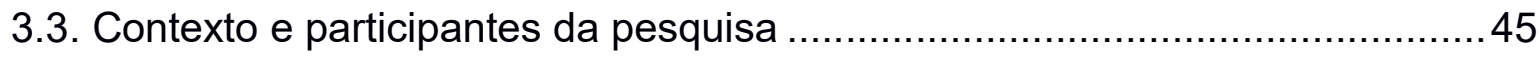

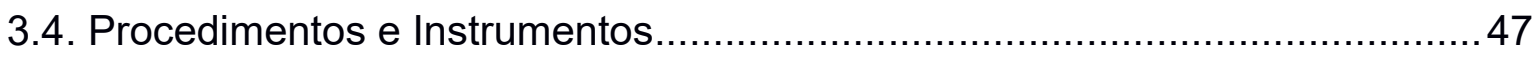

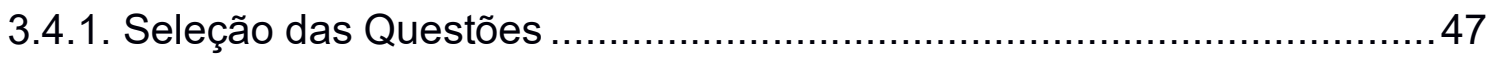

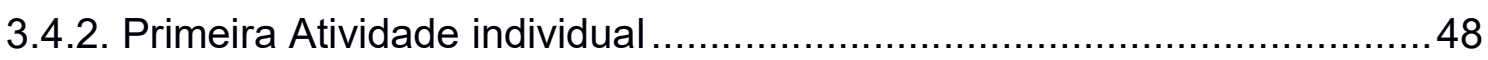

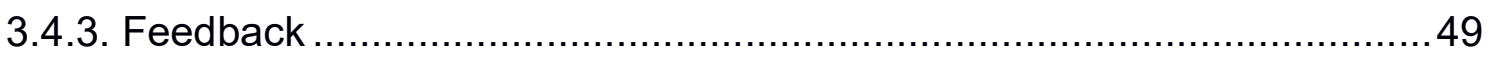

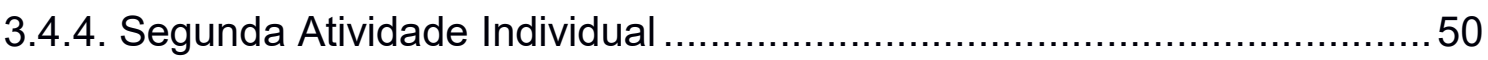

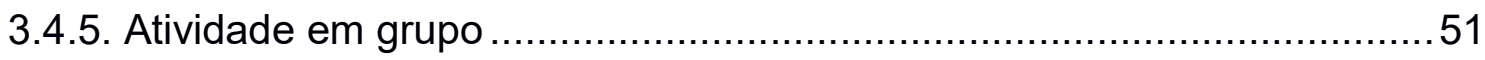

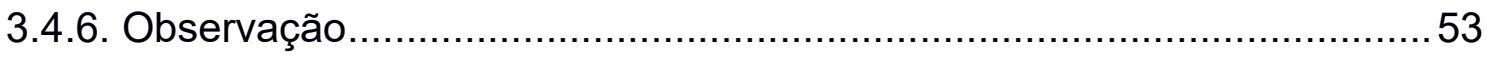

3.5. Procedimentos de Análise das Informações ......................................... 53 


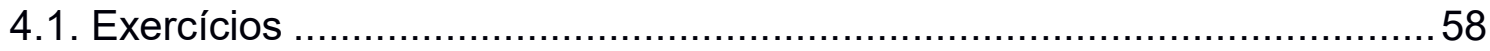

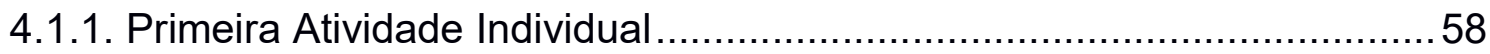

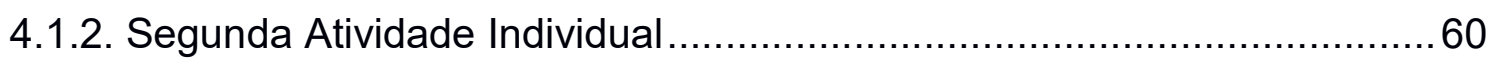

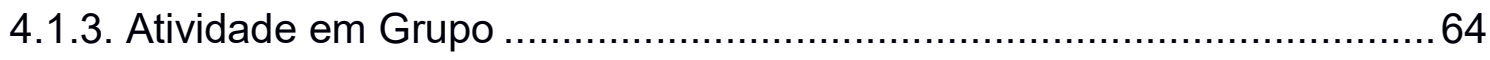

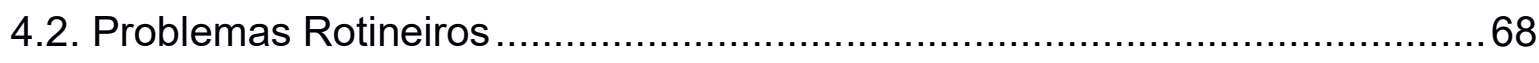

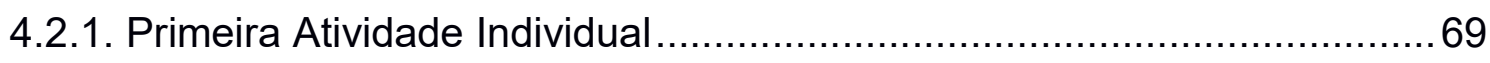

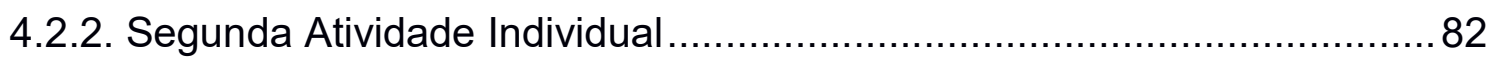

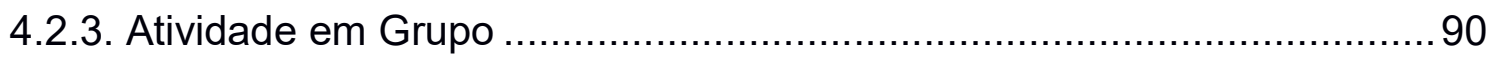

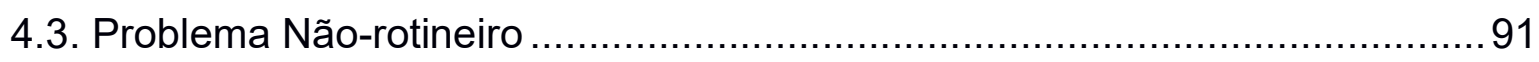

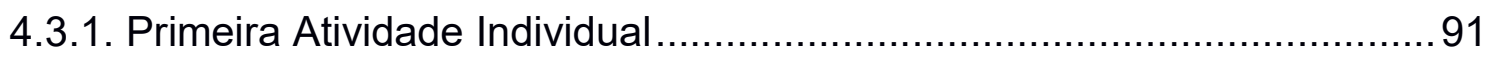

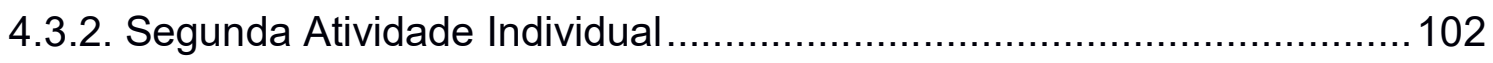

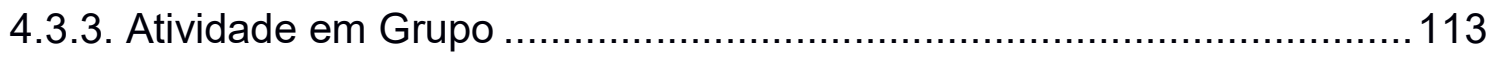

4.4. Sobre a motivação em matemática dos participantes .................................125

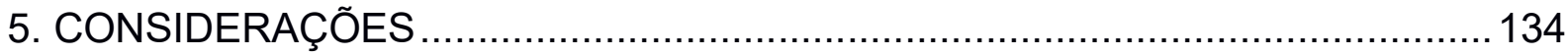

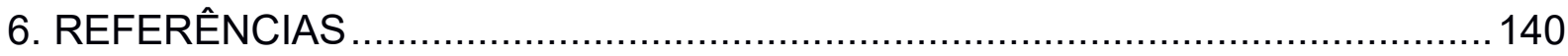

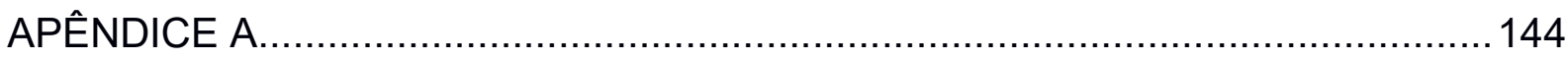

ANEXO A 


\section{APRESENTAÇÃO}

Nasci em 1988 na região administrativa de Ceilândia, Distrito Federal, e por lá estudei todo o meu Ensino Fundamental e Médio na mesma escola, de esfera particular. Talvez por minha formação da educação básica ter sido concretizada toda junto a mesma escola não tive experiências com outros projetos pedagógicos e, como consequência, minha concepção de ensino não teve grandes alterações no decorrer dessa fase, afinal, eu gostava daquela Instituição. Talvez o maior impacto sentido por mim foi do $5^{\circ}$ para o $6^{\circ}$ ano, à época denominados por $4^{\mathrm{a}}$ e $5^{\mathrm{a}}$ séries, respectivamente, naquele grande choque que muitos tendem a sofrer em função do aumento na quantidade de professores, pois, no lugar de apenas um passamos a ter uma variedade de professores, um para cada disciplina, cada qual com uma forma diferente de ensinar.

$\mathrm{Na}$ vida escolar fui uma aluna dedicada aos estudos, obtendo sempre boas notas. Sempre gostei de matemática obtendo bons rendimentos nessa disciplina. Por vezes não via sentido em estudar alguns conteúdos, mas não questionava os professores pois o meu papel naquela época, acreditava eu, era de estudar de forma passiva o que me era apresentado e proposto, tendo que obter boas notas. Nessa época, tive alguns professores de matemática que gostei mais do que de outros, mas vale destacar que de forma geral eles ensinavam de uma maneira tradicional, embasados na repetição de exercícios, inclusive os ditos "exercícios de fixação", cabendo a mim decorar de fórmulas e a maneira como aplicá-las para resolver as atividades propostas.

No ano seguinte ao término do Ensino Médio, ingressei no ensino superior no curso de licenciatura em matemática na Faculdade Santa Terezinha (2006-2008). Escolhi esse curso pelo fato de gostar de matemática apesar de não ter, à época, uma dimensão acurada do que era me constituir professora. Pensava que para ser professora bastava ter conhecimento do conteúdo que iria ser ensinado, mas felizmente após algum tempo de estudo na faculdade meu pensamento inicial sobre o que era importante para ser um bom profissional nessa área foi sendo alterado. Notei que para ser professora de matemática teria que ser uma profissional que tem conhecimento matemático sim, mas sobretudo, de conhecimento sobre a área de educação. 
A minha monografia, cujo título foi "A importância da escola na formação do cidadão: Algumas reflexões para o educador matemático" buscava destacar a escola como local onde o aluno é estimulado a desenvolver o pensamento crítico e autônomo para o convívio em sociedade.

Terminei a faculdade! Me graduei no final de 2008, muito animada como o propósito de me constituir professora e propor uma metodologia de ensinoaprendizado da matemática diferente do que eu havia tido contato enquanto aluna da educação básica. No entanto, só comecei a atuar como professora no ano de 2011, e confesso que após esse período sem contato com a área educacional esse desejo havia se enfraquecido. Nesse ano passei a trabalhar em três escolas diferentes e com realidades bastante diversas: fui aprovada no concurso da Secretaria Municipal de Educação do Valparaíso, região do entorno de Brasília - DF onde trabalhava com o Ensino Fundamental nas séries finais; comecei a atuar na Secretaria de Educação do Distrito Federal como professora temporária na região administrativa de Samambaia, DF, na Educação para Jovens e Adultos; e, ainda trabalhava em uma escola particular na região administrativa de Taguatinga, DF, com alunos do Ensino Médio.

Apesar da diminuição da motivação para atuar com um trabalho diversificado, ainda tinha vontade, mesmo que tímida, de ensinar de uma forma diferente da que a matemática vinha sendo ensinada, mas a realidade em sala de aula, cerca de 35 alunos por turma, extensão do currículo, a cobrança em ensinar todos os conteúdos do livro didático, falta de materiais pedagógicos, dentre outros fatores, foi me desmotivando ainda mais. Ensinava basicamente da mesma maneira que aprendi durante meus anos de educação básica. Tentava apresentar a matemática de uma forma mais contextualizada, mas ainda assim focava as atividades em sala na resolução de exercícios para que os alunos "treinassem" e "aprendessem" a forma de resolução, focando as atividades na memorização e repetição.

Mesmo propondo vários exercícios, grande parte dos alunos não conseguia compreender e aplicar o conteúdo em diversas situações do contexto matemático e de suas vidas. Sentia-me fracassada como professora pois não estava conseguindo auxiliar esses alunos a aprenderem matemática. Algumas vezes propunha atividades mais voltadas para a resolução de problemas para estimular a curiosidade e a consequente motivação dos alunos, mas ainda de uma forma muito esporádica. 
Em 2013, fui convocada para o concurso da Empresa de Correios e Telégrafos (ECT). Embora o salário fosse proporcionalmente menor, acabei optando por mudar de área de atuação pois estava desanimada em relação ao processo educacional e cansada pelo acúmulo de 3 empregos e assim, dessa forma, me afastei opcionalmente dos ambientes da sala de aula.

Em 2014, fui convocada no concurso para docente do Instituto Federal de Educação, Ciência e Tecnologia de Brasília - IFB. Os Institutos Federais foram criados em 2008 e são instituições de educação básica, profissional e superior. Fui lotada no campus Ceilândia, o qual ainda era uma Unidade em implantação/estruturação e, portanto, trabalhávamos em um espaço ainda precário com apenas duas salas de aula. Apesar da pouca infraestrutura, nesse local pude conviver com docentes motivados, que tinham uma visão diferenciada sobre a educação, com propostas metodológicas relacionadas ao processo ensinoaprendizado diferentes da que eu vinha utilizando em sala de aula anteriormente. Buscavam trabalhar de uma forma mais contextualizada e integrada com outros componentes curriculares, me estimulando a não ensinar a matemática de uma forma pura e isolada, mas de acordo com o contexto da realidade daqueles alunos e do curso que eles estavam matriculados. Esse ambiente renovou meu desejo de mudança em minha prática como docente.

Percebi, então, que não tinha muito conhecimento de temáticas relacionadas à área educacional de uma forma geral, e mais especificamente à educação matemática - eu queria mudar o meu trabalho em sala de aula, mas não sabia como, só sabia "dar aulas" naquele antiquado modelo que outrora eu criticara. Surgiu dessa forma a vontade de me capacitar para que pudesse ter práticas docentes mais voltadas para essa formação do cidadão que defendi durante minha graduação. Para buscar esse conhecimento me inscrevi como aluna especial no Programa de Pós-Graduação da Faculdade de Educação na Universidade de Brasília - UnB.

Em contato com essa atmosfera estimuladora passei a me aproximar de uma metodologia de ensino mais voltada para a resolução de problemas. Nessa época, eu trabalhava junto a turma de "Gestão e práticas empreendedoras para micro e pequenas empresas" na modalidade de Formação Inicial e Continuada - FIC propondo uma matemática mais aplicada a realidade dos alunos e mais significativa para que os mesmos pudessem construir e compreender os conceitos matemáticos 
visando aplicar em situações diversas de seu cotidiano e na atividade profissional que viriam a atuar.

Nessa oportunidade percebi que os alunos não estavam habituados a se deparar com atividades voltadas para a resolução de problemas. Eles sentiam dificuldade no processo de resolução pelo fato de estarem habituados a resolver os exercícios padronizados apresentados em livros didáticos, de uma forma mecânica, sem buscar investigar como tais situações poderiam ser solucionadas, e quando era proposto algum tipo de problema que fosse necessário uma resolução um pouco mais complexa, eles sentiam grandes dificuldades. E, dessa forma, meu objeto de pesquisa foi sendo amadurecido na concepção de analisar as estratégias que os alunos adotam quando estão diante de exercícios e de problemas, inicialmente classificados como rotineiros e não rotineiros, relacionados a área de razão e proporção.

Assim, ingressei no programa de mestrado do Programa de Pós-Graduação em Educação da Faculdade de Educação, Universidade de Brasília - PPGE/UnB, em 2015, e espero com essa pesquisa gerar contribuições à educação matemática, tanto ao meio acadêmico, na figura dos demais pesquisadores, quanto ao meio profissional, representado pelos docentes atuantes em sala de aula. 


\section{CAPÍTULO 1 - INTRODUÇÃO}

Neste capítulo será apresentado uma reflexão inicial sobre a relevância da resolução de problemas no processo de ensino e aprendizagem destacando a relevância da pesquisa proposta, sendo assim apresentada a justificativa da escolha do tema bem como os objetivos do presente trabalho.

\subsection{Justificativa: Científica e Social}

Os Parâmetros Curriculares Nacionais (PCN) do ensino médio, indicam que a matemática escolar visa desenvolver habilidades e competências que serão utilizadas na vida pessoal e profissional dos alunos

podendo formar no aluno a capacidade de resolver problemas genuínos,
gerando hábitos de investigação, proporcionando confiança e
desprendimento para analisar e enfrentar situações novas, propiciando a
formação de uma visão ampla e científica da realidade, a percepção da
beleza e da harmonia, o desenvolvimento da criatividade e de outras
capacidades pessoais (BRASIL, 2000, p.40).

Os PCN evidenciam a importância de favorecer que os estudantes desenvolvam um rol de habilidades e competências que lhes permitam, ao se depararem em seu cotidiano com problemas que envolvam conhecimentos matemáticos, possam ser capazes de analisar, compreender e propor soluções apropriadas. Isso é corroborado ainda pela perspectiva de que um dos principais papéis da escola é formar o aluno para o exercício pleno de sua cidadania (BRASIL, 1997), ao que se percebe a necessidade de capacitá-los de modo que os permitam resolver, de forma independente, os diversos problemas que enfrentarão no decorrer de suas vidas.

Branca (1997, p. 10) afirma que "embora não tenhamos um meio de saber como serão esses problemas, considerar a resolução de problemas segundo as diferentes interpretações pode ajudar a nos preparar para eles", enfatizando a importância e relevância de se trabalhar com essa temática para que a escola cumpra com sucesso o seu papel formador. Quanto mais problemas se conhece, maior será o arcabouço prévio de conhecimentos e estratégias a serem mobilizados para gerar novas soluções. 
Em complemento, Schoenfeld (2007a) reforça as afirmações anteriores pontuando que os alunos devem ser expostos a maior quantidade e variedade possível de experiências que desenvolvam habilidades matemáticas de raciocínio e pensamento abstrato. Nessa perspectiva, a sala de aula pode se tornar um espaço onde os alunos sejam encorajados a valorizar o pensamento empírico, autônomo e criativo, dentre outras características.

É válido ressaltar o que é ponderado por Valdés (2010, p. 7):

as matemáticas escolares, a nosso ver, são capazes de desenvolver nos alunos maneiras diferentes de pensar, em seguida, o aluno pode usar em sua futura atividade pessoal ou profissional para resolver os problemas e as tarefas que são apresentados.

Parece óbvio registrar que não se pode interpretar que o papel do estudante se limita a simplesmente repetir informações, ressaltando o fato de que a escola deve preparar o aluno para encarar os obstáculos que poderá enfrentar no decorrer de sua vida, razão pela qual torna-se necessário que sejam fomentadas estratégias diferenciadas de solução de problemas para que o discente esteja apto a obter êxitos diante desses desafios, ou seja, para que tenha um pensamento autônomo e não apenas centrado na repetição de formas de resolução.

Lester (2013, p. 246) destaca que "a maioria dos educadores matemáticos concordam que o desenvolvimento de habilidades de resolução de problemas dos alunos é um objetivo primário de instrução", razão pela qual é importante que o docente compreenda a dimensão de sua função, refletindo acerca da importância de trazer consigo o objetivo de alimentar tais habilidades em seus alunos. Por isso, é necessário que o professor esteja atento e motivado a analisar quais metodologias seriam adequadas para se atingir esses objetivos. Se o propósito do docente de matemática é formar um cidadão autônomo e capaz de atuar tanto na vida social quanto profissional e acadêmica, então para cumprir essa missão é importante considerar, como uma alternativa, que o discente seja provocado a trabalhar com problemas em sala de aula para que, tendo desenvolvido essa habilidade na escola, possa então ressignificar os demais conhecimentos para sua vida.

Diante da importância da resolução de problema para a formação do aluno, Onuchic e Allevato (2011, p. 82) apresentam algumas razões para se ter uma metodologia de ensino voltada para a resolução de problemas: 
- Resolução de problemas coloca o foco da atenção dos alunos sobre as ideias matemáticas e sobre o dar sentido.

- Resolução de problemas desenvolve poder matemático nos alunos, ou seja, capacidade de pensar matematicamente, utilizar diferentes e convenientes estratégias em diferentes problemas, permitindo aumentar a compreensão dos conteúdos e conceitos matemáticos.

- Resolução de problemas desenvolve a crença de que os alunos são capazes de fazer matemática e de que a Matemática faz sentido; a confiança e a auto-estima dos estudantes aumentam.

- Resolução de problemas fornece dados de avaliação contínua, que podem ser usados para a tomada de decisões instrucionais e para ajudar os alunos a obter sucesso com a matemática.

- Professores que ensinam dessa maneira se empolgam e não querem voltar a ensinar na forma dita tradicional. Sentem-se gratificados com a constatação de que os alunos desenvolvem a compreensão por seus próprios raciocínios. - A formalização dos conceitos e teorias matemáticas, feita pelo professor, passa a fazer mais sentido para os alunos.

De acordo com as autoras, o trabalho com resolução de problemas possui benefícios para os dois sujeitos envolvidos diretamente na dinâmica de sala de aula. Para os estudantes, pode se configurar como uma alternativa significativa de aprendizado e que promove um empoderamento em relação à matemática, bem como a mudança na forma com que o estudante se relaciona com essa área de conhecimento; enquanto que para o professor, os problemas podem se constituir em uma ferramenta didática que permite, inicialmente, apresentar muitos dos conteúdos escolares previstos no currículo, envolvendo os estudantes e contextualizando como a matemática se insere no dia a dia de todos, e também demonstrando como essa área de conhecimento transborda a dimensão curricular e perpassa a compreensão dos fenômenos da vida como ela é.

Em complemento à justificativa teórica apresentada até o momento, vale destacar dados estatísticos referentes ao desempenho dos estudantes brasileiros, oriundos dos resultados de avaliações de larga escala relacionadas a área de matemática. O Sistema de Avaliação da Educação Básica (SAEB) busca avaliar a educação básica no Brasil apontando indicadores para o desenvolvimento dos alunos do $5^{\circ}$ e $9^{\circ}$ ano do ensino fundamental e $3^{\circ}$ ano do ensino médio e é composto por 3 avaliações de larga escala: Avaliação Nacional da Educação Básica (ANEB), Avaliação Nacional do Rendimento Escolar (ANRESC, também denominada "Prova Brasil") e Avaliação Nacional da Alfabetização (ANA).

Nos resultados do SAEB/2015, em relação a proficiência média em matemática dos alunos do $3^{\circ}$ ano do Ensino Médio, Brasília possui o segundo maior escore $(280,1$ pontos), ficando atrás apenas do estado do Espírito Santo (281 pontos), sendo que a 
nota média obtida no Brasil é de 267 pontos. A escala utilizada para essa avaliação varia de 0 a 500 pontos, compreendendo 10 níveis de proficiência, sendo que Brasília se encontra classificada no nível 3 (BRASIL, 2016a). Pode-se perceber que a média do Distrito Federal é ligeiramente pouco acima da média nacional, muito embora esses resultados ainda possam demonstrar um baixo rendimento dos estudantes nas avaliações nacionais de larga escala.

Com relação a avaliações internacionais, podemos destacar o Programme for International Student Assessment (PISA), que é uma avaliação de nível internacional aplicada a estudantes com idade de 15 anos, independentemente do seu tempo de escolarização, visando avaliar o letramento em Matemática, Ciências e Linguagem. No caso da avaliação da área de matemática a escala de proficiência varia do nível abaixo de 1 ao nível 6 , sendo que melhor é considerado o letramento em matemática quanto mais próximo de 6.

O relatório do Instituto Nacional de Estudos e Pesquisas Anísio Teixeira (INEP) acerca da edição do PISA/2015, define o letramento matemático baseado principalmente em 3 verbos: formular, empregar e interpretar.

O processo de formulação indica quão eficazmente os alunos reconhecem e
identificam oportunidades para usar a matemática em situações-problema e
depois estabelecem a estrutura matemática necessária para formular esse
problema contextualizado em uma forma matemática; o de emprego, quanto
executam cálculos e manipulações e aplicam os conceitos e fatos que
conhecem para chegar a uma solução matemática para um problema
formulado matematicamente; o de interpretação, quão eficazmente são
capazes de refletir sobre soluções e conclusões matemáticas, interpretá-las
em um contexto do mundo real e determinar se os resultados ou conclusões
são razoáveis." (BRASIL, 2016b, p. 140).

A última edição do PISA aplicada na área de matemática foi em 2015, sendo que o relatório nacional do mesmo foi divulgado em novembro de 2016. $\mathrm{Na}$ área de matemática, o Brasil ficou na $66^{\circ}$ colocação dentre 70 países participantes. A nota média dos jovens brasileiros em matemática nessa avaliação foi de 377 pontos, significativamente inferior à média de 490 pontos dos estudantes dos países que fazem parte da OCDE (Organização para a Cooperação e Desenvolvimento Econômico). Com relação aos níveis relacionados a escala de proficiência em matemática, $70,25 \%$ dos estudantes não atingiram o nível 2 , o que configura um resultado preocupante, pois a OCDE, responsável por essa avaliação, indica que os conhecimentos associados a esse nível são essenciais para que o sujeito possa exercer sua cidadania (BRASIL, 2016b). 
Esses dados retratam que o processo de ensino-aprendizagem da matemática no Brasil não tem conseguido atingir bons resultados com relação à proficiência dos estudantes nas avaliações externas, reforçando que alterações no ensino da matemática devem ser propostas e que as pesquisas em ensino-aprendizagem da matemática devem ser estimuladas para encontrar possíveis alternativas e soluções para os problemas detectados.

Dessa forma, diante da exposição apresentada neste capítulo e considerando a potencialidade do uso de resolução de problemas com vistas a auxiliar o desenvolvimento do processo de aprendizagem da matemática, considerando a aplicação do conhecimento adquirido em sua vida diária, esta dissertação se ancora sob os seguintes questionamentos: Quais são as estratégias utilizadas pelos estudantes concluintes da educação básica para resolver diferentes tipos de problemas matemáticos relacionados aos conteúdos de razão e proporção? O que essa análise dos protocolos de resolução dos problemas permitirá inferir?

Sendo assim, pretende-se com a presente pesquisa analisar os processos de resolução de problemas rotineiros e não rotineiros, observando: Em qual tipo de problema os alunos tiveram maior índice de acerto? Que tipo de problema permitiu maior diversidade de resoluções? Quais as potencialidades de cada tipo de problema? Para tanto, será apresentado os conceitos de problemas rotineiros e não rotineiros nos quais a pesquisa se embasou.

Vale registrar que a opção em desenvolver a presente pesquisa com estudantes em fase de conclusão do ensino médio surge a partir do entendimento de que alunos dessa fase escolar já puderam ter um contato mais aprofundado com o conceito de razão e proporção em diversos momentos da sua vida escolar, provavelmente não apenas em matemática, mas também em outros componentes curriculares que utilizam desse conhecimento como instrumento de investigação.

Outro fator relevante para a escolha desse conteúdo é a aplicabilidade que os conceitos relacionados a razão e proporção possuem em atividades cotidianas vividas pelos sujeitos, possuindo características de versatilidade e transversalidade. Lembrando que o foco da pesquisa não está em reconhecer se o aluno sabe ou não esse conteúdo, mas há de se considerar que esse fator poderá aparecer com um dado importante a ser considerado na pesquisa. 


\subsection{Objetivo Geral}

Analisar as produções escritas de um grupo de alunos do $3^{\circ}$ ano do ensino médio de uma escola pública do Distrito Federal na resolução de atividades matemática.

\subsection{Objetivos específicos}

- Analisar os procedimentos empregados pelos alunos na resolução de exercícios, de problemas rotineiros e de problemas não rotineiros de matemática referentes à razão e proporção;

- Analisar os procedimentos empregados pelos alunos ao resolverem os problemas, tanto individualmente quanto em grupos. 


\section{CAPÍTULO 2 - DIALOGANDO COM OS AUTORES}

A seguir, busca-se abordar tópicos relevantes ao tema da pesquisa, para compor o arcabouço teórico, apresentando os principais conceitos e pressupostos sobre os quais essa pesquisa se encontra embasada, destacando as seguintes temáticas: conceito de problema, resolução de problemas e análise da produção escrita.

\subsection{Problemas: Conceito}

Diferentes estudos buscam apresentar concepções acerca de problemas. Segundo os PCN (BRASIL, 1997, p. 33) "um problema matemático é uma situação que demanda a realização de uma sequência de ações ou operações para obter um resultado. Ou seja, a solução não está disponível de início, no entanto é possível construí-la". Lester (2013) também apresenta uma forma semelhante para caracterizar um problema tratando-o como uma situação que não se sabe como obter sua solução imediatamente, quando se tem uma meta, mas sem saber, a princípio, como ela pode ser atingida.

Outros autores também frisam suas concepções acerca do que entendem por problema. Na perspectiva de Onuchic (1999, p. 215), um problema "é tudo aquilo que não se sabe fazer, mas que se está interessado em resolver", enquanto Schoenfeld (2013, p.10) mostra que, "resolução de problemas em sua forma mais geral foi definido como uma tentativa de conseguir algum resultado, quando não havia nenhum método conhecido (para o indivíduo a tentar alcançar esse resultado) para alcançá-lo".

Ressalte-se que as diferentes definições, apesar de utilizarem termos distintos, tem grande similaridade entre si, tendo em vista a aproximação dos conceitos que descrevem problema como algo cuja solução, ou percurso para encontrá-la, não se encontra definido imediatamente. Lester (2013, p. 24) ressalta que as pesquisas realizadas nessa área mostram definições convergentes, tendo em vista dois elementos em comum: "existe um objetivo e o indivíduo (o solucionador de problemas) não é imediatamente capaz de atingir a meta", destacando o entendimento de que 
para que uma atividade seja considerada um problema é imprescindível que o solucionar esteja motivado a resolver e que esse não saiba como resolvê-lo de imediato.

Ainda nesse contexto, Schoenfeld (2007a) faz uma crítica ao que foi outrora considerado problema, mostrando que nem todo exercício contextualizado é verdadeiramente um problema, tendo em vista que os dados necessários para sua resolução já foram fornecidos no enunciado ou são facilmente obtidos, sem levar o aluno a uma reflexão ou análise mais aprofundada. $O$ autor ainda afirma que nem toda questão dita difícil é um problema, pois se a forma de resolução for conhecida pelo sujeito que se propôs a resolver, esse conseguirá obter a solução ainda que a referida tarefa demande certo tempo de operacionalização, não sendo, dessa forma, um problema de fato. Dessa maneira o que é problema para uma pessoa pode não ser para outra devido ao estágio de desenvolvimento e de conhecimento em que cada uma se encontra, donde se é possível depreender que uma determinada atividade ser ou não considerada um problema é relativo ao sujeito que se propõe em resolver (LESTER, 2013; SCHOENFELD, 1992).

Registre-se que similar é a ideia trazida pelos $\mathrm{PCN}$, os quais pontuam que:

o problema certamente não é um exercício em que o aluno aplica, de forma quase mecânica, uma fórmula ou um processo operatório. Só há problema se o aluno for levado a interpretar o enunciado da questão que lhe é posta e a estruturar a situação que lhe é apresentada (BRASIL, 1997, p. 32).

Por vezes, os exercícios propostos aos alunos possuem uma característica tão restrita que apenas requerem a aplicação de uma fórmula ou a repetição de modelos previamente estudados em sala de aula. Schoenfeld criticava, já em 1992, a forma como a resolução de problemas vinha sendo tratada no contexto de muitas escolas, onde os alunos normalmente tinham contato com situações que requeriam, em geral, a imediata aplicação de algum procedimento específico com vistas a se alcançar o resultado numérico esperado - não tratando de resolver um problema de fato, em seu sentido amplo e com a análise das variáveis envolvidas.

Apesar do conceito de problema, convergir considerando alguns autores, as classificações dos tipos de problemas são variadas. Diversos autores propõem diferentes tipos de classificação, nomenclatura e definições para diferentes tipos de problemas. Neste trabalho, classificaremos os problemas em dois tipos, rotineiros e não rotineiros. Optou-se por essa classificação por considera-la abrangente e próxima 
aos conceitos propostos por Polya (1985, p. 13), que diz que "o problema que não se resolve por rotina exige um certo grau de criação e originalidade por parte do aluno, enquanto o problema de rotina não exige nada disso".

\subsection{Tipos de Problemas: rotineiros e não rotineiros}

Os "problemas de rotina podem ser resolvidos usando procedimentos familiares aos estudantes por meio da replicação de métodos anteriormente aprendidos em um passo-a-passo" (WOODWARD et al, 2012, p.11). Nestes problemas sabe-se imediatamente, ou quase imediatamente, o procedimento de resolução a ser utilizado, podendo ser considerado por vezes trivial, sendo a resolução alcançada a partir de uma aplicação direta e/ou mecânica de um algoritmo. Problemas similares a essa classificação também são chamados de problemas convencionais (STANCANELLI, 2001) e problema-padrão (DANTE, 2009).

Polya (1985, p. 14) também faz distinção entre dois tipos de problemas rotineiros "o problema que exige tão somente a aplicação de uma regra bem conhecida e o problema que não é senão uma simples questão de vocabulário". No primeiro caso, entende-se uma atividade voltada para o uso de um algoritmo ou processo voltado para a reprodução quase mecânica de um conhecimento, geralmente pensado pelo professor para verificar se o aluno compreendeu a forma/regra de aplicação do conceito ou um algoritmo (DANTE, 2009; POLYA, 1985; SCHOENFELD, 1992), já no segundo caso refere-se a um problema mais contextualizado, que demanda certa interpretação, mas sendo um problema mais simplificado.

Vale destacar que essa pesquisa considerou o primeiro tipo de problema rotineiro, apresentado como exercício. Mayer (2003) corrobora com essa forma de tratamento pelo fato de que se o sujeito que se propôs a resolver já conhece o algoritmo a ser usado, esse não teria empecilho em resolver tal atividade, e por isso mesmo, não se enquadra em algumas definições de problemas que se valem do pressuposto que o respondente de início não possua um caminho pronto ao encontro da solução.

Já o segundo tipo, são problemas rotineiros, geralmente contextualizados, mas que não exigem o desenvolvimento de estratégias para a resolução. Schoenfeld 
(1992) chama esse tipo de problema de "Word problem", os quais são problemas que possuem uma história, podendo ser relacionada ao contexto real, onde "a forma mais eficiente para resolver os problemas era a leitura do texto, ignorando o 'contexto do mundo real'. Os alunos aprenderam a escolher os números, identificar a operação para executar, fazer o cálculo, e escrever a resposta" (SCHOENFELD, 2007b, p. 70) podendo então, esse tipo de problema, ser comparado a uma questão de vocabulário como citado por Polya, podendo assim ser considerado uma textualização. Um exemplo desse tipo de problema é a seguinte questão: "Mei-Ling, de Singapura, estava preparando-se para uma viagem de 3 meses à África do Sul como aluna de intercâmbio. Ela precisava trocar alguns dólares de Singapura (SGD) por rands sulafricanos (ZAR). Mei-Ling descobriu que a taxa de câmbio entre o dólar de Singapura e o rand sul-africano era: $1 \mathrm{SGD}=4,2$ ZAR. Mei-Ling trocou 3000 dólares de Singapura por rands sul-africanos a esta taxa de câmbio. Quantos rands sul-africanos Mei-Ling recebeu?"1- Nesse problema, os principais dados a serem utilizados, bem como a forma de resolução, são identificados mais claramente.

Vale considerar ainda que os problemas rotineiros não precisam ter apenas um "passo" para resolução, podendo apresentar diversas etapas, embora requeiram métodos de resolução familiares ao sujeito que se propõe a resolver, como por exemplo: "Alguns exames médicos requerem uma ingestão de água maior do que a habitual. Por recomendação médica, antes do horário do exame, uma paciente deveria ingerir 1 copo de água de 150 mililitros a cada meia hora, durante as 10 horas que antecederiam um exame. A paciente foi a um supermercado comprar água e verificou que havia garrafas dos seguintes tipos:

- Garrafa I: 0,15 litro

- Garrafa II: 0,30 litro

- Garrafa III: 0,75 litro

- Garrafa IV: 1,50 litro

- Garrafa V: 3,00 litros

A paciente decidiu comprar duas garrafas do mesmo tipo, procurando atender à recomendação médica e, ainda, de modo a consumir todo o líquido das duas

\footnotetext{
1 Disponível no link

<http://download.inep.gov.br/download/internacional/pisa/ltens_Liberados_Matematica.pdf >. Acesso em: 10 dez. 2016
} 
garrafas antes do exame. Qual o tipo de garrafa escolhida pela paciente?" (Enem, 2015). Sendo que esse poderia ser classificado como um problema rotineiro apesar de sua resolução demandar alguns "passos" e de apresentar um certo grau de dificuldade para alguns estudantes.

Os problemas não rotineiros, por sua vez, segundo Elia, Heuven-Panhuizen e Kolovou (2009, p. 606) são aqueles no qual se "pretende alcançar uma situação solicitada, mas não se sabe um caminho direto de acesso ou cumprimento de seu objetivo", desconhecendo, dessa forma um procedimento imediato que o conduza a solução, guardando um contraste com os problemas rotineiros que envolvem a aplicação de procedimentos recorrentes. Essa concepção corroborada por outros autores, como Mayer (2003) e Woodward et al (2012), se aproxima mais da definição de problema apresentado anteriormente nessa pesquisa. Além disso, ressalte-se que nem toda situação contextualizada ou difícil pode ser caracterizada como um problema.(ONUCHIC; ALLEVATO, 2011).

Para esse tipo de problema, Dante (2009) ainda propõe a nomenclatura de problemas-processo ou heurísticos, indicando que esses não podem ser solucionados por uma aplicação direta de um algoritmo, pois necessitam que o aluno reflita sobre o que o problema está propondo, havendo a necessidade de se elaborar um plano para se obter o resultado, possibilitando o desenvolvimento de um espírito explorador que leve os alunos a elaborar os seus próprios métodos de resolução.

Esses problemas podem se tornar um fator de estímulo aos alunos pois mesmo que o aluno tenha conhecimento/domínio do algoritmo será necessário que se tenha uma reflexão sobre o problema, havendo a necessidade do desenvolvimento de uma estratégia apropriada para a resolução. Nessa ótica o problema não rotineiro possibilita um pensamento mais livre e autônomo por parte do estudante, ao se propor uma atividade a qual sua solução não Ihe é familiar, estimulando inclusive a adoção da modelagem e do uso da criatividade em matemática.

Destaque-se ainda que a resolução de exercícios também possui certa relevância no processo de aprendizagem, constituindo-se em "exercícios de fixação" ou ainda exercícios algoritmos (DANTE, 2009; POLYA, 1985; WOODWARD et al, 2012), pois eles podem auxiliar os estudantes a praticar a forma de desenvolvimento de algoritmos diversos, adquirindo assim maior familiaridade com os conceitos e com o trato numérico. Logo, há de se considerar o papel desses, contudo, vale salientar a 
importância de não se utilizar apenas esse tipo de problema no processo ensinoaprendizagem.

Diniz (2001, p. 99) destaca que os livros didáticos, de uma forma geral, são centrados em problemas rotineiros com as seguintes características:

\begin{abstract}
textos na forma de frases, diagramas ou parágrafos curtos; os problemas vem sempre após a apresentação de um determinado conteúdo; todos os dados de que o resolvedor necessita aparecem explicitamente no texto e, em geral, na ordem em que devem ser utilizados nos cálculos; os problemas podem ser resolvidos pela aplicação direta de um ou mais algoritmos; a tarefa básica na sua resolução é identificar que operações são apropriadas para mostrar a solução e transformar as informações do problema em linguagem matemática; a solução numericamente correta é um ponto fundamental, sempre existe e é única.
\end{abstract}

Nesse contexto, podem ser identificados fatores desfavoráveis relacionados a se trabalhar basicamente com problemas rotineiros como, por exemplo, os estudantes serem levados a pensar que problemas geralmente possuem um método pronto para a resolução; que problemas são resolvidos sempre da mesma forma; ou ainda que sempre possuem uma solução. Assim, o aluno pode passar a associar a resolução de problemas a determinados conteúdos, questionando frequentemente que fórmula utilizar em determinada questão ou gerando associações entre determinadas estratégias de resolução e a existência de determinadas palavras ou expressões presentes no texto da atividade, não sendo estimulado dessa forma a pensar em outras possibilidades para se resolver os problemas que the são propostos, fortalecendo assim uma visão reducionista desse rico recurso de aprendizado.

Schoenfeld (1992) destaca que os problemas não rotineiros se caracterizam por requerer uma habilidade mais elevada de resolução de problema que o aluno demonstrará na medida que desenvolva suas habilidades na resolução de demais problemas, ainda que rotineiros. Pode-se atribuir tal observação ao fato de que para se resolver problemas não rotineiros existe a necessidade de se ter conhecimentos prévios, experiências em resolução de diversos tipos de problemas, buscando maior flexibilidade nas estratégias de resolução construídas.

Dessa forma, o conhecimento prévio do sujeito que se propõe a resolver pode ser considerado um dos fatores que influenciam na classificação de um problema como rotineiro ou não rotineiro, bem como o momento em que o problema é proposto. Por exemplo, ao considerarmos o seguinte problema: "Se uma fazenda tem 20 animais entre galinhas e vacas, totalizando 64 patas, quantas vacas e galinha tem a 
fazenda?", se esse problema for aplicado junto a uma turma logo após a introdução do conteúdo de sistemas de equações do $1^{\circ}$ grau, ele poderá se constituir um problema rotineiro para muitos alunos, embora ao ser abordado em um outro momento ou visando uma forma de introdução a esse conteúdo, poderá se tornar não rotineiro, tendo em vista a ausência da rotina dos estudantes em se trabalhar com o conteúdo específico normalmente associado a essa atividade. Dessa forma, reafirmase que ser ou não ser um problema é relativo, de acordo com o sujeito que o resolve, pois, para um aluno ele pode ser rotineiro e para outro não rotineiro, de acordo com o desenvolvimento cognitivo/estágio de desenvolvimento de cada um.

Diante do exposto, pode-se perceber que não existe uma classificação única e imutável de um problema em rotineiro ou não rotineiro, sendo que essa varia conforme entendimento do sujeito que está se propondo a resolvê-lo. Sendo assim, o fator de maior influência na classificação do problema será o de se esse apresenta ou não um caminho possivelmente reconhecido com mais clareza pelo sujeito que se propõe a resolver.

\subsection{Resolvendo problemas}

Como o objetivo da pesquisa se ancora nas estratégias dos alunos para a resolução de problemas, vale fazer algumas considerações sobre as formas de resolução de problemas de acordo com alguns autores. Polya (1994), em seu livro "Arte de Resolver Problemas", busca sistematizar alguns procedimentos voltados para a resolução de problemas. Na parte 1 da referida obra, o autor explicita, de uma forma geral, um rol que apresenta "uma relação de operações mentais típicas e úteis na resolução de problemas" (POLYA, 1994, p. 87), sendo agrupadas em 4 fases, reunindo indagações que orientam a reflexão/debate para a resolução. A seguir, uma síntese de cada uma das fases segundo a compreensão do autor:

- Compreender o problema: para resolvê-lo de forma correta é essencial que se tenha entendido o que se espera da atividade em tela, o contexto da situação, o que se está sendo esperado. Nesse sentido é importante considerar as partes principais, analisando os dados apresentados e aqueles a serem inferidos, as incógnitas envolvidas, os condicionantes do problema, questionando se é preciso de mais dados para se resolver, ou não, adotando uma notação apropriada. 
Essa categoria está subdividida em outros dois estágios: familiarização e aperfeiçoamento da compreensão. Na familiarização, tem-se a absorção do enunciado, seguida da busca de uma visão do problema de forma global, conhecendo seu contexto e a situação proposta. Já no aperfeiçoamento da compreensão, buscase uma releitura do mesmo para obter melhor clareza, seleção das partes principais, considerando-as inicialmente de forma isolada para fazer posteriormente uma relação entre as mesmas. Os principais questionamentos dessa fase são: quais os dados? quais as condicionantes? a condicionante é suficiente para determinar a incógnita?

- Estabelecer um plano: nessa fase o solucionador busca estabelecer um roteiro geral para se resolver o problema, é onde se define como esse será resolvido analisando a forma como os dados estão relacionados e buscando traçar estratégias para a resolução. $O$ autor destaca nesse momento a importância de se ter conhecimento prévio relacionado ao problema a ser resolvido, pois para se traçar um plano é essencial ter conhecimento que seja suficiente para que o solucionador possa conjecturar sobre suas estratégias de resolução. (POLYA, 1994).

O sujeito que está se propondo a resolver o problema pode pensar sobre alguma atividade análoga/correlata, que tenha a mesma ou similar estrutura e verificar a possibilidade de se transpor a estratégia utilizada outrora. Caso não conheça problemas semelhantes o solucionador pode tentar modificar/variar o problema proposto levando a atividades auxiliares ou, ainda, buscando resolver um problema mais específico, correlato ou genérico mais acessível, de maneira a trabalhar com parte das condicionantes para buscar algum dado que lhe possa ser útil. Esse pode ser considerado um momento propício para que o professor possa provocar o aluno com indagações e sugestões que o aproxime de um caminho à descoberta.

Alguns questionamentos típicos dessa fase são: já resolveu/viu/teve contato com problema semelhante? Se sim, é possível usar esse método de resolução ou fazer algumas adaptações para utilizá-lo? É necessário encontrar novos dados/variáveis para conseguir resolver? É possível modificar o problema?

Em tempo, cabe destacar que, após uma profunda reflexão na fase de planejamento sobre o problema e do emprego de diversas tentativas não exitosas, o sujeito pode ter um insight. O insight "é um entendimento notável e, algumas vezes, aparentemente súbito de um problema ou de uma estratégia que ajuda a solucionáIo" (STERNBERG, 2010, p.397) combinando conhecimentos prévios e um novo olhar 
sobre o problema, analisando sobre óticas diversas. Vale destacar que o insight pode ocorrer em qualquer momento após essa reflexão mais aprofundada do problema, até mesmo após o término do momento proposto para a resolução do problema.

- Execução: é o momento de se colocar em prática o plano para a resolução, buscando analisar o roteiro proposto para que fique claro o caminho a ser desenvolvido verificando os passos de resolução.

- Retrospecto: revisita-se a maneira como foi executado a resolução, observando seu processo como um todo para consolidar e aperfeiçoar o conhecimento desenvolvido no decorrer do processo. Nessa fase vale destacar a importância de, se possível, verificar o resultado obtido, interpretando o significado de tal achado e refletindo se o mesmo é adequado ao contexto do problema. Vale destacar que, ainda nesse momento, é importante que o sujeito possa questionar se o problema poderia ser resolvido de maneiras diferentes e em que outros tipos de problema poderiam ser aplicadas estratégias análogas a essa.

Essas quatro fases foram listadas na ordem em que geralmente ocorrem, mas isso não significa que ocorram de forma contínua ou consecutiva. Sendo assim, essas fases propostas apenas indicam, de uma forma geral, um horizonte para o processo de resolução, reconhecendo que nem sempre são respeitadas a linearidade entre as fases e sequer o cumprimento rígido de todas elas.

O delineamento da estratégia para resolução de problemas é uma das capacidades fundamentais, relacionadas a área de matemática, necessária para desenvolver o letramento matemático, sendo as demais: comunicação; "matematização"; representação; raciocínio e argumentação; utilização da linguagem simbólica, forma e técnica, e operações; e utilização de ferramentas matemáticas. 


\section{Figura 1: Relação entre processos matemáticos (na coluna) e habilidades matemáticas fundamentais (na linha)}

\begin{tabular}{|c|c|c|c|}
\hline & $\begin{array}{l}\text { Formular situações } \\
\text { matematicamente }\end{array}$ & $\begin{array}{l}\text { Empregar conceitos, } \\
\text { fatos, procedimentos e } \\
\text { raciocínios matemáticos }\end{array}$ & $\begin{array}{l}\text { Interpretar, aplicar e avaliar } \\
\text { resultados matemáticos }\end{array}$ \\
\hline Comunicar & $\begin{array}{l}\text { Ler, decodificar e interpretar } \\
\text { afirmações, perguntas, tarefas } \\
\text { ou objetos para criar um } \\
\text { modelo mental da situação. }\end{array}$ & $\begin{array}{l}\text { Articular uma solução, } \\
\text { mostrar o trabalho envolvido } \\
\text { no alcance da solução e/ou } \\
\text { resumir e apresentar resultados } \\
\text { matemáticos intermediários. }\end{array}$ & $\begin{array}{l}\text { Construir e apresentar } \\
\text { explicações e argumentos no } \\
\text { contexto do problema. }\end{array}$ \\
\hline Raciocinar e argumentar & $\begin{array}{l}\text { Explicar, defender ou fornecer } \\
\text { uma justificativa para a } \\
\text { representação identificada ou } \\
\text { elaborada de uma situação do } \\
\text { mundo real. }\end{array}$ & $\begin{array}{l}\text { Explicar, defender ou fornecer } \\
\text { uma justificativa para os } \\
\text { processos e procedimentos } \\
\text { usados para determinar } \\
\text { um resultado ou solução } \\
\text { matemática; conectar partes } \\
\text { de informações para chegar a } \\
\text { uma solução matemática, fazer } \\
\text { generalizações ou criar um } \\
\text { argumento com várias etapas. }\end{array}$ & $\begin{array}{l}\text { Refletir sobre soluções } \\
\text { matemáticas e criar explicações } \\
\text { e argumentos que corroborem, } \\
\text { refutem ou qualifiquem uma } \\
\text { solução matemática para um } \\
\text { problema contextualizado. }\end{array}$ \\
\hline $\begin{array}{l}\text { Utilizar linguagem simbólica, } \\
\text { formal e técnica e fazer } \\
\text { operações }\end{array}$ & $\begin{array}{l}\text { Usar variáveis, símbolos, } \\
\text { diagramas e modelos } \\
\text { padronizados adequados a fim } \\
\text { de representar um problema } \\
\text { do mundo real usando uma } \\
\text { linguagem simbólica/formal. }\end{array}$ & $\begin{array}{l}\text { Entender e utilizar construtos } \\
\text { formais com base nas } \\
\text { definições, regras e sistemas } \\
\text { formais, bem como empregar } \\
\text { algoritmos. }\end{array}$ & $\begin{array}{l}\text { Entender a relação entre o } \\
\text { contexto do problema e a } \\
\text { representação da solução } \\
\text { matemática; usar esse } \\
\text { entendimento para ajudar } \\
\text { a interpretar a solução no } \\
\text { contexto e estimar a viabilidade } \\
\text { e as possíveis limitações da } \\
\text { solução. }\end{array}$ \\
\hline $\begin{array}{l}\text { Usar ferramentas } \\
\text { matemáticas }\end{array}$ & $\begin{array}{l}\text { Utilizar ferramentas } \\
\text { matemáticas para reconhecer } \\
\text { estruturas ou descrever relações } \\
\text { matemáticas. }\end{array}$ & $\begin{array}{l}\text { Conhecer e ser capaz de } \\
\text { empregar adequadamente } \\
\text { várias ferramentas que podem } \\
\text { auxiliar na implementação de } \\
\text { processos e procedimentos } \\
\text { para determinar soluções } \\
\text { matemáticas. }\end{array}$ & $\begin{array}{l}\text { Usar ferramentas matemáticas } \\
\text { para garantir a aceitação de } \\
\text { uma solução matemática } \\
\text { e de quaisquer limitações } \\
\text { e restrições nessa solução, } \\
\text { considerando o contexto do } \\
\text { problema. }\end{array}$ \\
\hline
\end{tabular}

Fonte: BRASIL (2016b, p. 144).

Essas 7 capacidades matemáticas fundamentais subjacentes aos processos matemáticos foram destacadas pelo PISA 2015, indicando que estão intimamente relacionadas ao processo de resolução de problemas. Acreditamos ser possível 
estabelecer um paralelo com as 4 etapas propostas por Polya (1994) relacionando-as com essas capacidades matemáticas subjacentes.

- Compreender o problema: comunicar e "matematizar".

- Estabelecer um plano: representar, raciocinar e argumentar, delinear estratégias para a solução de problemas.

- Execução: Representar, "matematizar", utilizar linguagem simbólica, formal e técnica e fazer operações, usar ferramentas matemáticas.

- Retrospecto: estaria mais ligado não a especificamente uma dessas capacidades matemáticas fundamentais subjacentes aos processos matemáticos, mas sim ao verbo "interpretar" proposto como uma das capacidades do letramento matemático onde se destaca a necessidade de se refletir sobre as soluções e interpretar os resultados obtendo conclusões relacionadas ao contexto proposto no problema.

Relacionando os demais verbos ligados ao letramento matemático, "formular" estaria relacionado a compreender o problema e "empregar" a estabelecer um plano e execução.

Pode-se perceber que Polya destaca etapas para a resolução de problemas numa perspectiva mais individualista, relacionando o sujeito e o processo de resolução do problema, dessa forma, vale considerar o processo de resolução de problemas numa ótica coletiva. Onuchic e Allevato (2011) propõem um roteiro com orientações sobre uma metodologia de como se trabalhar com resolução de problemas em sala de aula composto de 9 momentos:

a) Preparação do problema: momento de seleção dos problemas a serem trabalhados, sendo previamente selecionados e/ou elaborados;

b) Leitura individual: essa fase conta com a reserva de momento para que cada participante possa fazer uma leitura silenciosa do problema proposto;

c) Leitura em conjunto: destinado momento para uma leitura em conjunto onde os alunos poderão debater sobre os dados apresentados e solicitados no problema;

d) Resolução do problema: momento livre, onde os alunos serão estimulados a utilizar as estratégias que considerarem mais adequadas para a resolução do mesmo; 
e) Olhar e incentivar: a professora tem o papel de mediar o processo de resolução, observando e estimulando os alunos/participantes no referido processo, dotando o participante de papel ativo nesse processo;

f) Registro das resoluções na lousa: um representante do grupo registrará o processo de resolução na lousa, apresentando as estratégias traçadas e como pensaram para obter aquela resposta, ou caso não tenham obtido a resposta apresentem suas percepções com relação a situação proposta e prováveis motivos pelos quais não conseguiram avançar na resolução;

g) Plenária: debate sobre as diferentes formas de resolução propostas pelos participantes analisando as características das resoluções apresentadas.

h) Busca de consenso: após debate das estratégias no momento anterior, busca-se junto a turma encontrar a(s) resposta(s) correta(s) para o problema;

i) Formalização do conteúdo: realização de uma apresentação formal, considerando a linguagem matemática, considerando as resoluções propostas bem como destacando as técnicas envolvidas nos processos.

A proposta das autoras é muito interessante, tendo em vista o estímulo a participação dos estudantes ativamente na resolução dos problemas bem como a troca de experiência entre os grupos, onde pode verificar a resolução dos demais colegas considerando as diferenças de raciocínios para obter a resposta, percebendo que pode não existir uma forma única para se resolver um problema.

\subsection{Análise da produção escrita}

A partir dos registros das soluções propostas pelos estudantes na resolução de problemas é possível perceber diferentes facetas dos processos de pensamento utilizados na construção das soluções, bem como a forma de interpretação do enunciado e dados fornecidos, as estratégias e conceitos que optaram, os equívocos e acertos mais recorrentes, entre outros. Dessa forma, Cury (2008, p. 13), ressalta que

qualquer produção, seja aquela que apenas represente uma resoluçãomodelo, seja a que indica a criatividade do estudante, tem características que permitem detectar as maneiras como o aluno pensa e, mesmo, que influências ele traz de sua aprendizagem anterior, formal ou informal. Assim, analisar as produções é uma atividade que traz, para professor e para os alunos, a possibilidade de entender, mais de perto, como se dá a apropriação do saber pelos estudantes. 
Diante da riqueza das informações que podem ser obtidas na análise da produção dos alunos há que se considerar que as estratégias de resolução propostas, por vezes, não são muito valorizadas, tampouco devidamente exploradas para verificar como os alunos apreenderam os objetos do conhecimento trabalhos em sala de aula e a relação deles com problemas propostos pelo professor.

Dessa forma, vale destacar a relevância da análise dessa produção, pois, esta pode favorecer ao professor compreender onde e porque os alunos estão errando para poder intervir, bem como conhecer as estratégias de resolução, corretas, que podem possuir certo grau de originalidade e que podem se constituir em novas opções para serem utilizadas pelos demais alunos. Assim, o professor pode repensar os seus planejamentos de ensino a fim de atender às diferentes necessidades dos alunos, bem como buscar estratégias que estimulem o desenvolvimento dos potenciais por eles apresentados.

Ao se considerar apenas se a resolução está certa ou errada, perde-se o processo de desenvolvimento e construção das estratégias do aluno e a possibilidade de averiguar as prováveis causas que impossibilitaram o aluno a obter o resultado esperado. Nessa ótica é importante observar a forma com que o aluno se propôs a resolver, conjecturando sobre suas possíveis dificuldades, tendo em vista que "diferentes tipos de erros exigem diferentes ações do professor, a primeira coisa a fazer é o professor aprender a identificá-los, distinguir qual a natureza de cada um deles, bem como que ações realizar para que sejam superados" (SILVA; BURIASCO, 2005, p. 501).

Sendo assim, o professor possui um papel relevante nesse processo de aprendizado, assim como o aluno que ao fazer uma análise de suas produções é estimulado a uma reflexão sobre sua aprendizagem, possibilitando perceber suas dificuldades e pensar em maneiras de superá-las, sendo enfatizado a uma constante verificação e autocorreção. Vale destacar ainda a importância de que o aluno tenha liberdade para se arriscar em estratégias de resolução menos rotineiras e oportunidade de realizar tentativas, pois pode haver diferentes formas de resolução para se resolver um mesmo problema, e, caso a solução seja errada, possa também identificar o motivo da falta de precisão em suas resoluções, para aprender com suas experiências e superar os possíveis obstáculos que o levaram uma solução incorreta. 
Cury $(2008$, p. 63$)$ pontua que:

na análise das respostas dos alunos, o importante não é o acerto ou o erro em si - que são pontuados em uma prova de avaliação da aprendizagem -, mas as formas de se apropriar de um determinado conhecimento, que emergem na produção escrita e que podem evidenciar dificuldades de aprendizagem.

Nesse sentido, pode-se dizer, a partir da análise da produção escrita do estudante, o que ele aprendeu, o que ele está ainda em processo de aprendizagem e o que ainda não apreendeu. Coloca-se como exemplo o caso de um estudante cuja solução foi considerada parcialmente correta por acertar parte do procedimento. Embora não tenha produzido a resposta esperada, demonstrou certo entendimento acerca do contexto apresentado e das relações entre os dados do problema, o que implica na necessidade de uma análise sobre o motivo de ter ocorrido o referido erro, em uma ação conjunta entre o docente e o estudante, que elaborarão uma proposta para a superação das dificuldades encontradas. Ressalta-se que o docente deve assumir o papel mediador entre o que o aluno já sabe e o conhecimento ainda em desenvolvimento, estimulando uma participação ativa do estudante nesse processo.

Buriasco e Ciani (2016, p. 67) destacam que com essa prática de se analisar as respostas dos alunos:

os professores têm a oportunidade de conhecer o fazer matemática de seus alunos, a atividade de matematizar, respeitando peculiaridades; de ampliar as possibilidades de guiar o processo de aprendizagem e, de modo especial, de tomar os alunos como participantes ativos do processo educacional.

Nessa ótica, os professores passam a conhecer o processo de resolução dos alunos e a forma como eles pensam, pois nem sempre resolvem os problemas da mesma forma, podendo ainda não resolver da maneira como o professor ensinou fato inclusive que deve ser estimulado pelo docente para nutrir a liberdade e a autonomia do estudante, afinal características como essa podem contribuir no estímulo da criatividade dos mesmos. Nesse sentido, os problemas não rotineiros caracterizam-se justamente por possibilitar essa maior liberdade para pensar, tendo em vista que sua forma de resolução não está explicitamente definida em sua leitura inicial. O aluno é estimulado a refletir e elaborar uma estratégia para a resolução a partir de sua interação com o problema.

Buriasco e Ciani (2016, p. 60) percebem a análise da produção escrita como:

uma estratégia para implementação da avaliação como prática de investigação, ela se mostra como um caminho para conhecer múltiplos aspectos da atividade matemática dos alunos e, também, como uma 
possibilidade para capacitar o professor e reorientar sua prática pedagógica, inclusive para estabelecer conexões entre um modo particular de representar utilizado com o mais formal.

Esse papel investigativo da avalição permite obter diversos dados, entre eles, identificar a forma como os alunos estão resolvendo as questões e os enganos mais recorrentes. Considerar a avaliação nessa perspectiva vai além de se compreender apenas se a questão está certa ou errada, mas sim uma forma de utilizar esse instrumento a favor da aprendizagem do aluno. E é nessa perspectiva que se insere o papel do feedback avaliativo.

O feedback tem um papel central no processo avaliativo, sendo um eixo norteador para o aprendizado do estudante a partir da devolutiva que esse recebe após análise de sua produção. Diversos autores (FERNANDES, 2009; OECD/CERI, 2008; BROOKHART, 2008) defendem a prática do feedback como elemento da avaliação numa perspectiva formativa, uma avaliação para a aprendizagem, onde o foco do processo encontra-se no aluno. Esse feedback pode ser oferecido tanto pelo docente quanto pelos próprios estudantes, numa perspectiva de avaliação entre/por pares.

Nessa perspectiva, busca-se que o feedback estimule o estudante a avançar no seu processo de aprendizagem, superando as dificuldades e explorando as suas potencialidades, tanto individualmente quanto na sua interação com seus pares. $O$ feedback também possibilita ao estudante perceber os seus erros e a agir para verificar as possibilidades de evitar comete-los novamente. Trata-se de um processo contínuo, que deve ser realizado não somente a partir de instrumentos avaliativos, mas desenvolvido cotidianamente de modo favorecer que o estudante perceba as evidências de como está evoluindo o seu processo de aprendizado.

Surge assim a necessidade de se debater com os alunos sobre seus desempenhos, destacando as dificuldades e limitações apresentadas por meio de um feedback contínuo, tanto individualmente quanto de forma coletiva. Dessa forma, os estudantes perceberão as possíveis razões que justificam os procedimentos inadequados utilizados na resolução de problemas, bem como poderão desenvolver estratégias de autoconhecimento acerca de sua forma de aprendizagem. 


\subsection{Razão e Proporção}

Acerca do conteúdo de razão e proporção, Obando, Vasco e Arboleda (2014, p.72) destacam a importância de pesquisas relacionadas a essa temática, visto considerarem um

campo privilegiado para investigações em virtude de seu lugar central na matemática escolar, que relaciona áreas conceituais necessárias para a compreensão e modelagem de múltiplas situações de matemática, das ciências naturais e sociais e diárias.

Diante da relevância desse conteúdo, foi analisado o currículo da Educação Básica da Secretaria de Estado de Educação do Distrito Federal (SEEDF) - Currículo em Movimento da Educação Básica, Anos Finais do Ensino Fundamental e Ensino Médio - para que se pudesse verificar como e quando a temática razão e proporção se encontra contemplada nesse documento norteador.

No $6^{\circ}$ ano, por exemplo, a temática razão e proporção não se destaca isoladamente, mas surge no trato de conhecimentos relacionados ao desenvolvimento dos conceitos de fração e transformações de unidades de medidas; enquanto no $7^{\circ}$ ano esses conceitos são diretamente abordados - os alunos começam a conhecer as grandezas diretamente e inversamente proporcionais, regra de três simples e composta, porcentagem e juros simples. Nessa ocasião, os alunos já são formalmente apresentados à regra de três, um dos principais algoritmos para a resolução de problemas relacionados à razão e proporção.

Já no $8^{\circ}$ ano essa temática não aparece explicitamente. No $9^{\circ}$ ano, consta razão de semelhança, semelhança de triângulos, proporções e teorema de Tales que envolvem alguns conceitos relacionados a razão e proporção. Nessa etapa escolar, o conceito de razão e proporção tem uma abordagem mais voltada para a área de geometria, de forma a permitir aos alunos comparar segmentos e/ou figuras semelhantes, verificando como elas aumentam ou diminuem de acordo com a razão, sendo desenvolvido um aprofundamento nessa área também sob uma ótica visual.

Em geografia pode-se perceber conceitos ligados à razão e proporção relacionados a área de cartografia ao se trabalhar com mapas e escalas.

No $1^{\circ}$ ano do ensino médio, os conceitos de razão e proporção são retomados, relacionando-os à área de Matemática Financeira, junto a conhecimentos de porcentagem e juros simples. Vale destacar que esses conceitos já foram trabalhados 
com os alunos no $7^{\circ}$ ano, mas diante de sua relevância ele torna a ser trabalhado com os estudantes, que agora no $1^{\circ}$ ano já possuem um conhecimento prévio e experiências diferentes com relação a matemática dos que tinham outrora. Os problemas aqui trabalhados tendem a ter, evidentemente, um grau de complexidade maior do que quando estavam sendo apresentados a tais conceitos.

No Ensino Médio também é possível perceber esse conhecimento não apenas em matemática. $\mathrm{Na}$ área de ciências da natureza podemos utilizar conhecimentos relacionados a razão e proporção em conteúdos como grandezas químicas, estequiometria, sistema internacional de unidades, velocidade, aceleração, características de fluídos (densidade) e genética. Já em ciências humanas pode-se perceber em densidade demográfica ou populacional. Esses são apenas alguns exemplos da aplicação dos conceitos de razão e proporção, evidenciando que os mesmos devem ser trabalhados em forma espiral, pois possuem aplicações interdisciplinares, estando presentes em diferentes etapas do percurso formativo na educação básica.

No caso de razão e proporção, para se resolver um problema, geralmente é necessário recorrer a diversos conceitos e conhecimentos prévios, dentre eles as operações básicas cuja conceitualização requer estruturas aditivas, multiplicativas, relação entre grandezas, percepção de padrões, dentre outros. Nessa ótica, o desenvolvimento de um conceito não pode ser compreendido como algo isolado, mas como algo que estabelece uma relação em conjunto com diversas situações, construído ao longo da vida do indivíduo, baseado também em suas experiências, de maneira que "cada conceito é constituído a partir de uma rede conceitual mais ampla" (MUNIZ, 2009, p. 134). Dessa forma, ficou evidenciado que por vezes, os conceitos relacionados a razão e proporção não surgem em caráter explícito, mas aliados/junto/inseridos em outros conceitos, o que reforça sua aplicação interdisciplinar.

Em nosso cotidiano, os conhecimentos relacionados a razão e proporção também estão bastante presentes como em uma compra em um supermercado quando se busca relacionar a quantidade e o preço de um produto para saber qual embalagem é mais vantajosa, para modificar a quantidade dos ingredientes a serem utilizados em uma receita, para proceder cálculos relacionados a porcentagem (juros, descontos), na transformações/conversão de unidades de medidas muito presentes 
no dia-a-dia como kg para g; hora para minutos e/ou segundo; dentre outras situações. Assim sendo, o trabalho pedagógico com esses conceitos pode ser realizado por meio das experiências prévias que os alunos possuem em relação a eles.

Além da presença dos referidos conteúdos no Currículo em Movimento da Educação Básica - Anos Finais do Ensino Fundamental e Ensino Médio, pôde-se perceber que razão e proporção foi um dos tópicos de conteúdo abordado na avaliação do PISA 2015. Vale destacar que os conteúdos que foram selecionados para fazer parte da referida avaliação são considerados de grande importância para que os alunos "se tornem cidadãos construtivos, engajados e reflexivos, capazes de tomar decisões e fazer julgamentos bem fundamentados" (BRASIL, 2016b, p. 147). Com relação ao conteúdo de razão e proporção foi observado a "descrição numérica de magnitude relativa e aplicação de proporções e raciocínios com proporcionalidade para resolver problemas" (BRASIL, 2016b, p. 148).

Vale destacar ainda que Obando, Vasco e Arboleda (2014, p. 68) realizaram um estudo sobre o estado da arte relacionado a razão e proporção na Colômbia. Esses, documentaram "haver uma tendência generalizada dos estudantes em aplicarem modelos lineares (em geral o uso de regra de 3) até em situações onde não eram aplicáveis" apresentando assim que grande parte dos alunos resolviam os problemas relacionados a razão e proporção pautando-se na regra de 3 .

Ainda referente a essa pesquisa, os autores destacam que uma possível razão para a ocorrência desse fator se dá pelo fato de que a regra de 3 geralmente é aplicável em diversos problemas relacionados a razão e proporção, dessa maneira generalizam a forma de resolução de questões relacionadas a essa temática à aplicação desse algoritmo, sendo considerado então um obstáculo epistemológico onde os alunos, ao perceberem que o problema se trata de razão e proporção, já "montam" a memorizada "regra de 3".

A generalização dessa forma de resolução para problemas que envolvam razão e proporção acaba sendo um resultado do processo de ensino. Cabe, então, refletir sobre a forma como esse conteúdo vem sendo abordado em sala de aula a fim de tornar o processo de aprendizagem mais significativo e sem vinculações com modelos específicos de aplicação desses conceitos. Nessa ótica o professor pode atuar como mediador, orientando os alunos a conhecerem mais profundamente os conceitos relacionados à razão e proporção, principalmente em situações cotidianas, onde eles 
possam entender como se resolve, o porquê de se solucionar de uma ou outra determinada maneira, bem como que não existe apenas uma única forma de se resolver. Ideal parece ser que o professor não ensine apenas o procedimento de regra de 3 , visto que se o aluno compreender a lógica do algoritmo e o significado do mesmo, ele poderá solucionar diversos problemas distintos. É importante que o aluno tenha experimentado diversos tipos de problemas relacionados a razão e proporção, bem como problemas que envolvam diversos tipos de grandezas (conversão de unidades de medida, velocidade), interpretação de tabelas e gráficos, problemas que estimulem os alunos a modelarem a resolução, dentre outros, tendo que refletir sobre os dados propostos e elaborar um plano para a resolução, e não apenas aplicar diretamente uma regra de 3.

Cury (2008, p. 35) enfatiza a necessidade de "abandonar a simples transmissão de conhecimentos e tentar, com experiências em sala de aula, encorajar os alunos a explorar e verbalizar suas ideias, raciocinar e argumentar". A autora ressalta a importância de que seja possibilitado ao aluno o formular de hipóteses, o analisar de conceitos, o estabelecer de comparações e o propor de teorias, acreditando que assim, o estudante poderá alcançar uma participação ativa no processo de aprendizagem. 


\title{
CAPÍTULO 3 - PERCURSO METODOLÓGICO
}

Neste capítulo serão discutidos elementos acerca do percurso metodológico e dos instrumentos que foram adotados em busca de se alcançar os objetivos desta pesquisa.

\subsection{Fundamentos Teórico-Metodológicos}

Partindo do entendimento de Fiorentini e Lorenzato (2006, p. 65), os quais defendem que "a solução dos problemas educacionais passa primeiramente pela interpretação e compreensão dos significados atribuídos pelos envolvidos, ou melhor pelos sujeitos que experimentam o fenômeno", este trabalho se propõe a obter uma compreensão acerca das estratégias de resolução de problemas adotadas por estudantes concluintes do ensino médio, sendo caracterizado um fenômeno constituído em meio ao processo de ensino-aprendizagem da matemática.

Dessa forma, a pesquisa se aproxima dos pressupostos epistemológicos da fenomenologia no sentido que Gil (2008, p. 14) apregoa, ao pontuar que esse tipo de pesquisa "não procura explicar mediante leis, nem deduzir com base em princípios, mas considera imediatamente o que está presente na consciência dos sujeitos", o que sugere, em outras palavras, que a atenção da pesquisa se volta a busca pela compreensão do fenômeno e como esse se apresenta com foco no processo em análise, nesse caso portanto, tendo por foco o processo de resolução de problemas por parte dos sujeitos envolvidos na pesquisa.

Para o delineamento da pesquisa e de acordo com o objetivo elencado nessa dissertação optou-se pela proposição de um estudo de caso, o qual é conceituado por Alves-Mazzotti (2006, p. 643) como uma estratégia

\begin{abstract}
geralmente usada quando as questões de interesse do estudo referem-se ao como e ao porquê; quando o pesquisador tem pouco controle sobre os acontecimentos; e quando o foco se dirige a um fenômeno contemporâneo em um contexto natural.
\end{abstract}

Ainda sobre o estudo de caso, Godoy (1995, p. 25) reforça que esse "visa ao exame detalhado de um ambiente, de um sujeito em uma situação em particular" sendo, portanto, um estudo aprofundado de um objeto específico, considerando como o mesmo se manifesta em seu contexto. 
Dessa forma, a pesquisa foi desenvolvida com apenas uma turma a fim de favorecer uma maior integração com o professor e com os estudantes, bem como poder analisar em profundidade os protocolos de resolução dos problemas desenvolvidos ao longo das atividades. Além disso, não há a intenção de se fazer comparações entre as resoluções de estudantes de turmas diferentes.

Em prosseguimento, tendo em vista a necessidade de se descobrir e compreender os processos, experiências, as formas de pensamento e considerações feitas pelos participantes, optou-se por fazer uma análise qualitativa entendendo que o conjunto dessas características se encontra naturalmente associado às pesquisas desse tipo, segundo o que trazem Denzin e Lincoln (2006) e Harwell (2011). No entanto, há ainda que considerar que dados qualitativos poderão ser organizados de forma quantitativa, em se tratando de variáveis nominais, objetivando facilitar a visualização dos mesmos e possibilitando assim melhor fundamentação e enriquecimento da análise a ser realizada em sua completude (FLICK, 2009; GIL, 2008)

Vale considerar o que Creswell (2010, p. 211) afirma acerca da pesquisa qualitativa:

a pesquisa qualitativa é uma pesquisa interpretativa, com o investigador
tipicamente envolvido em uma experiência sustentada e intensiva com os
participantes. Isso introduz uma série de questões estratégicas, éticas e
pessoais ao processo de pesquisa qualitativa.

$E$, dessa forma, atinente à questão ética, entendemos que se torna importante apresentar algumas considerações a esse respeito em meio ao desenvolvimento da pesquisa idealizada.

\subsection{Considerações Éticas}

Por se tratar de uma pesquisa que envolverá a participação de pessoas, surge a necessidade de reflexões que objetivam preservar a integridade e validade/credibilidade da pesquisa buscando respeitar os princípios éticos para com todos os sujeitos envolvidos, no decorrer do transcurso do trabalho.

Houve um momento inicial destinado a explicitar aos possíveis participantes a forma como ocorreria a pesquisa a qual foram convidados a participar, fornecendo todos os esclarecimentos necessários relacionados à mesma. Foi solicitado então, 
aos que desejassem fazer parte da pesquisa, que fosse assinado o Termo de Consentimento Livre e Esclarecido (Apêndice A). O referido termo foi assinado por um dos responsáveis do participante, nos casos dos menores de idade, ou pelo próprio participante quando esse era maior de idade, concordando com a participação e registrando por escrito esse interesse.

Os participantes foram esclarecidos sobre o caráter voluntário da pesquisa e, portanto, da possibilidade de desistência a qualquer momento, livre de qualquer ônus. Assim, buscamos seguir as orientações de Gil (2008, p. 107), que destaca que "as pessoas que participam de qualquer pesquisa tem não apenas o direito de ser informadas acerca dos propósitos da pesquisa, mas também o de recusar-se a participar dela". Foi explicitado também que os dados fornecidos pelos participantes seriam utilizados apenas para a realização de pesquisas acadêmicas pela pesquisadora responsável, respeitando o devido sigilo e confidencialidade das informações prestadas por cada voluntário.

Fato importante salientado junto aos participantes é de que a participação dos sujeitos da pesquisa se daria em atividades relacionadas à resolução de problemas a fim de se coletar os dados para a pesquisa, não possuindo em sua essência qualquer propósito invasivo que pudesse implicar dano e/ou prejuízo aos voluntários.

\subsection{Contexto e participantes da pesquisa}

A pesquisa foi realizada em uma escola de ensino médio localizada na região administrativa de Ceilândia/DF. A escolha do contexto da pesquisa se deu pelo fato da pesquisadora possuir certo conhecimento da realidade histórica e cultural do referido local, tendo em vista que mora a mais de 25 anos nessa região. Além disso, o ambiente de trabalho da pesquisadora é próximo ao local na qual a pesquisa foi realizada, favorecendo o acesso à escola.

A instituição de ensino selecionada é uma escola pública integrante da rede de instituições de ensino da Secretaria de Estado de Educação do Distrito Federal SEDF.

Segundo o documento "Enem por Escola"2 publicado pelo INEP para mostrar dados estatísticos acerca da educação brasileira, identificou-se que a escola onde

\footnotetext{
2 disponível em http://portal.inep.gov.br/web/enem/enem-por-escola.
} 
ocorreu a pesquisa localiza-se na área urbana e que possuía 513 alunos no ano de 2015, cuja taxa de participação no Exame Nacional do Ensino Médio naquele ano foi de 83,63\%. Especificamente em matemática, a média dos 30 melhores alunos da escola foi de 657,47 , tendo sido alcançado 466,21 como média de todos os participantes da instituição de ensino. Acerca do nível de proficiência em matemática dos alunos dessa referida escola foram obtidos os seguintes percentuais:

Tabela 1: Nível dos alunos em matemática da escola participante da pesquisa

\begin{tabular}{ccccc}
\hline $\begin{array}{c}\text { Percentual } \\
\text { todos alunos } \\
\text { NÍVEL 1 }\end{array}$ & $\begin{array}{c}\text { Percentual } \\
\text { todos alunos } \\
\text { NÍVEL 2 }\end{array}$ & $\begin{array}{c}\text { Percentual } \\
\text { todos alunos } \\
\text { NIVEL 3 }\end{array}$ & $\begin{array}{c}\text { Percentual } \\
\text { todos alunos } \\
\text { NÍVEL 4 }\end{array}$ & $\begin{array}{c}\text { Percentual } \\
\text { todos alunos } \\
\text { NÍVEL 5 }\end{array}$ \\
\hline 50,12 & 32,63 & 13,75 & 3,26 & 0,23
\end{tabular}

Fonte: Elaborado pela pesquisadora

De acordo com a nota explicativa do $\operatorname{INEP}^{3}$, cada nível é definido a partir de diferentes intervalos de pontuação, conforme descrito a seguir:

I. Menor de 450

II. De 450 a 549,99

III. De 550 a 649,99

IV. De 650 a 749,99

V. Igual ou maior que 750,00

Os dados divulgados e apresentados mostram que mais da metade dos estudantes daquela Instituição de Ensino sequer alcançaram nota de 450 pontos (valor mínimo que é considerado para se promover a certificação do ensino médio) e ainda evidencia que um número inferior a $4 \%$ dos estudantes conquistam os dois últimos níveis de proficiência.

Para a realização da pesquisa, buscou-se uma aproximação junto à direção da escola, coordenador pedagógico e um professor de matemática regente de uma turma de $3^{\circ}$ ano do ensino médio regular. O professor que colaborou com a pesquisa demonstrou interesse na proposta idealizada, disponibilizando algumas aulas para o desenvolvimento das atividades propostas. A turma partícipe da pesquisa possuía 42 alunos matriculados.

3http://download.inep.gov.br/educacao basica/enem/nota tecnica/2015/nota explicativa enem2015 por escola.pdf), 


\subsection{Procedimentos e Instrumentos}

Foram realizados cinco encontros com a turma. Ressalte-se que o primeiro encontro foi realizada uma parte introdutória da pesquisa na qual a mesma foi apresentada sendo lido e entregue Termo de Consentimento Livre e Esclarecido. Nos 4 demais encontros foram realizadas as seguintes atividades: atividade individual, momento de feedback e atividade em grupo, conforme fluxo a seguir:

Figura 2: Fluxo de pesquisa

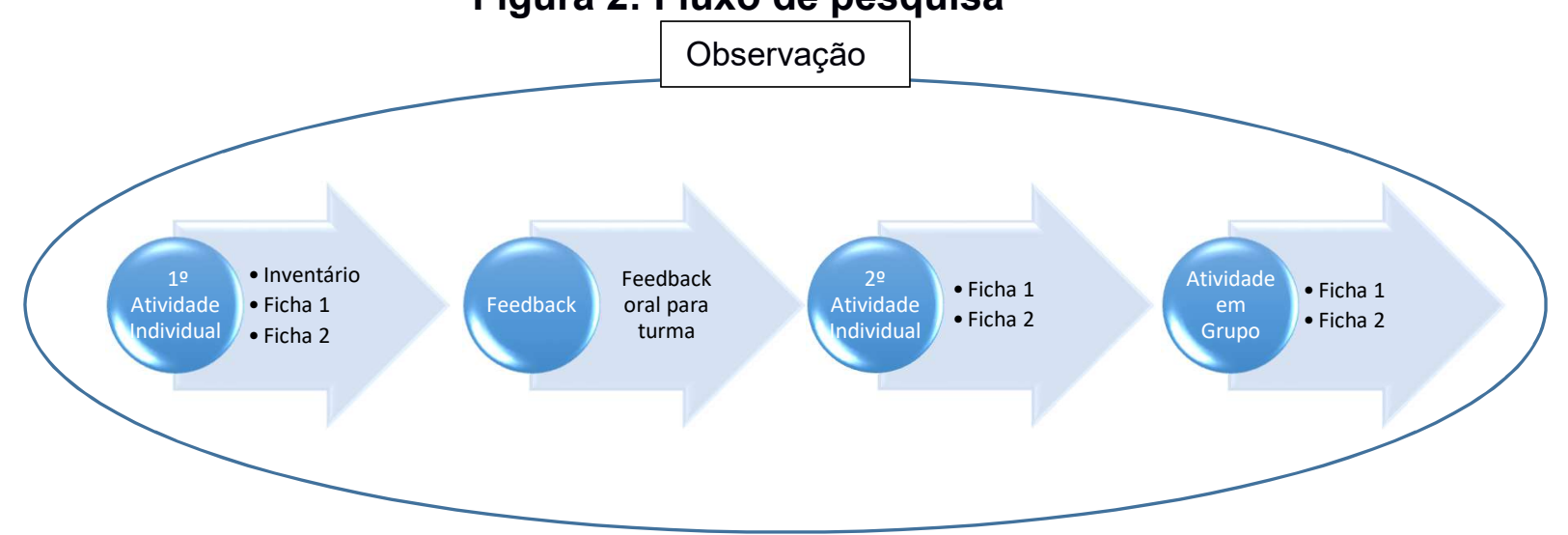

Fonte: Elaborado pela pesquisadora

Para a realização das atividades, o professor regente da turma participante da pesquisa disponibilizou aulas duplas para cada atividade individual e em grupo, e uma aula simples para a atividade de Feedback, o tempo de cada aula foi de 50 minutos.

Ademais cumpre registrar que a observação foi realizada durante todo 0 transcurso da atividade de campo. A seguir, serão apresentados os detalhamentos sobre cada uma das etapas presentes no fluxo apresentado.

\subsubsection{Seleção das Questões}

Apesar de não ser um conteúdo que está explicitamente no currículo do ensino médio, por sua relevância e aplicabilidade na realidade e em outros componentes curriculares como já comentado anteriormente, foi possível encontrar algumas questões diretamente relacionadas a essa temática em avaliações voltadas para o nível médio. Optou-se por selecionar problemas que já tivessem sido aplicados em algum tipo de avaliação oficial, preferencialmente de larga escala. Nesse sentido, 
buscou-se questões relacionadas ao conteúdo de razão e proporção em avaliações como o Enem, Pisa, vestibulares, Olimpíadas Brasileiras de Matemática das Escolas Públicas (OBMEP), dentre outros.

Logo, os critérios de seleção dos problemas foram:

1) Questão que já foi aplicada em uma prova e não foi anulada;

2) Nível de dificuldade adequado a um aluno concluinte do ensino médio.

Cabe ressaltar que as questões foram selecionadas de maneira que houvesse certo aumento no grau de dificuldade de uma atividade para a outra.

Os problemas selecionados tinham um contexto real, e em geral se aproximavam da realidade do aluno abordando situações relacionadas a shows, deslocamentos e passeios entre outros. Nessa ótica, os problemas trabalhados nas atividades tem um contexto realístico, sendo que Ferreira e Buriasco (p. 242, 2016) destacam que

\begin{abstract}
o termo "realistic" [...]" foi traduzido, para o português, também pelo GEPEMA, para "realístico" ao invés de "realista", porque parece estar mais relacionado ao significado de "imaginar", "realizar", "fazer ideia", "tomar consciência de" e, por sua vez, à possibilidade de "tornar real" na mente dos estudantes, o que sugere que os contextos ou situações nos quais os alunos se envolvem não precisam ser "autenticamente reais", mas precisam ser imagináveis, realizáveis, concebíveis.
\end{abstract}

Apesar de algumas não serem de um contexto tão próximo à realidade do aluno como a quantidade de voltas de um astronauta ao redor da terra, são questões com um contexto real que favorecem a interpretação dessas questões pelos alunos e não contextos desconexos, sendo que esse contexto pode ser imaginado por um aluno para interpretar e compreender o problema proposto.

Além dos problemas rotineiros e não rotineiros, também foram utilizados na pesquisa algumas questões denominadas por exercícios, caracterizadas pela ausência de contextualização e com uma abordagem mais voltada para a resolução algorítmica, envolvendo ações do tipo "resolva", "calcule,", "efetue". Os exercícios utilizados foram elaborados pela pesquisadora, inspirados em alguns livros didáticos.

\title{
3.4.2. Primeira Atividade individual
}

As atividades individuais foram divididas em dois momentos: resolução da primeira ficha seguido da resolução da segunda ficha. A primeira ficha continha dois problemas rotineiros (problemas de interpretação de texto) e dois problemas não 
rotineiros, relacionados ao conteúdo de razão e proporção. A segunda ficha continha dois exercícios e foi entregue aos alunos após a devolução da primeira ficha.

A proposta de apresentar o exercício em momento posterior à resolução dos problemas rotineiros e dos problemas não rotineiros se deu pelo fato de possibilitar que os alunos tenham contato primeiramente com os problemas para que eles não fossem induzidos a resolvê-los baseado nos exercícios que foram propostos. Ressalte-se que houve em cada questão um campo destinado para que o aluno pudesse descrever "como pensou" para resolver cada problema, visando melhor compreensão pela pesquisadora das estratégias envolvidas no desenvolvimento da resolução.

Cabe frisar que, antes de se iniciar a primeira atividade individual, foi aplicado um inventário visando ter uma caracterização/perfil dos participantes da pesquisa no que tange sua relação com a matemática, buscando compreender o envolvimento desses com essa área do conhecimento. Para tanto, foi utilizado o inventário "Minhas atitudes em relação a matemática" (ANEXO A) proposto por CHACÓN (2003), por meio do qual o participante manifesta sua opinião sobre a matemática completando frases com a ideia que vier à sua mente.

\subsubsection{Feedback}

Após a realização da primeira atividade individual, conforme descrito na seção anterior, fora realizada a análise das produções buscando verificar como os alunos resolveram os problemas, bem como as estratégias adotadas por eles, explorando o potencial das informações produzidas e coletadas.

Dessa forma, os protocolos com as resoluções dos alunos foram analisados e categorizados visando proporcionar um momento de feedback junto aos estudantes para que, a partir de uma devolutiva coletiva, pudessem refletir sobre a maneira como trataram o problema e perceber novas e/ou diferentes possibilidades de abordagem, ou seja, a partir do que Buriasco e Ciani (2016, p.65) apregoam, quando diz que "a ação do aluno de rever a estratégia adotada, os procedimentos desenvolvidos, as decisões tomadas, suas conclusões, pode ser originada por um feedback no contexto de uma prática reflexiva". Afinal, o aluno pode ser estimulado após um momento de feedback a avançar sobre a forma como respondeu e compreender possíveis 
caminhos de resolução, ampliando o seu repertório para aplicar em momentos futuros de resolução de novos problemas, percebendo a evolução do seu aprendizado. Motivado por tais argumentos que se buscou, no segundo encontro, realizar junto aos alunos um momento de feedback relacionado às questões da $1^{\circ}$ atividade.

No segundo encontro, os estudantes foram distribuídos em 8 grupos de aproximadamente 5 pessoas a partir de uma organização aleatória. Em seguida, foram apresentadas as formas de resolução dos alunos que acertaram os problemas, bem como os equívocos mais recorrentes em cada questão. Essa divisão em grupos foi idealizada para favorecer um momento de interação e troca de experiências entre os alunos com relação às suas resoluções, possibilitando a interação entre os pares. Essa interação pôde ser percebida durante o momento de feedback, no qual a pesquisadora comentava acerca das formas de resoluções dos problemas que tinham sido propostas e os alunos conversavam no grupo com os outros participantes como tinham resolvido tais atividades.

No momento em que foi realizado o feedback com os alunos também se abordou a temática relacionada à resolução de problemas, exemplificando acerca de formas e estratégias para se resolver problemas matemáticos. Previamente, os estudantes foram questionados sobre o que eles faziam diante de um problema. Como resposta, indicou-se que a primeira coisa a fazer é lê-lo, interpretá-lo, destacar as informações fornecidas e realizar as devidas operações. Foi salientada a importância de ler o problema mais de uma vez, buscando entender o contexto bem como a elaborar um plano para a resolução conforme seus conhecimentos. Reforçou-se a necessidade de ter tranquilidade ao se executar o plano que pensou, destacando algumas etapas, à luz do que foi proposto por Polya (1986), a saber: compreensão do problema, elaboração de um plano, execução do plano e verificação do resultado, que podem ajudá-los a resolver os problemas matemáticos a que estão se propondo a resolver. Esses passos, de maneira geral, são semelhantes aos propostos por Sternberg (2010), que enfatiza a importância da identificação do problema, definição e representação da situação, formulação de estratégia, organização das informações, alocação de recursos, monitoramento e avaliação.

\subsubsection{Segunda Atividade Individual}


No terceiro encontro com os alunos foi realizada uma segunda atividade individual, seguindo os mesmos padrões da primeira atividade, que requereu dos alunos, individualmente, a resolução das questões propostas.

\subsubsection{Atividade em grupo}

Após a realização das duas atividades individuais, foi realizada a atividade em grupo de uma forma similar a atividade individual, anteriormente apresentada. A proposta de se fazer atividades em grupo visava estimular a troca de experiência entre os pares, interação entre os participantes. A riqueza da atividade pode ser caracterizada pelo uso de um mesmo tipo de padrão de comunicação, no qual os signos e símbolos são comuns aos estudantes, favorecendo a troca de informações a partir de representações semelhantes e também da manifestação de diferentes pontos de vistas.

Buscou-se então promover um ambiente estimulador onde os participantes pudessem debater e discutir sobre diferentes formas de resolução, como eles poderiam resolver e elaborar um plano em comum para a resolução dos problemas propostos. Buriasco e Ciani (2016, p. 64) destacam que "as discussões em sala de aula proporcionam um ambiente no qual os alunos são incentivados a organizar, mostrar e defender suas produções, ideias e argumentos, tanto para o professor, quanto para os outros colegas". Esse momento possibilitou a troca de experiências entre os alunos e o compartilhamento de diferentes formas de resolução, de modo que um pôde perceber como o outro resolveria, tendo um olhar diferente sobre sua estratégia de resolução.

Para esse momento, a turma foi dividida em grupos de 4 ou 5 participantes. Os grupos foram compostos pela pesquisadora buscando promover uma interação entre os que tiveram um maior escore de acerto nas atividades individuais com aqueles que tiveram um escore menor. Especificamente, os grupos foram divididos conforme os escores obtidos pela média aritmética das duas atividades individuais. Primeiramente, essas médias foram organizadas da maior para a menor, e a divisão foi feita de maneira que o aluno que demonstrou o melhor desempenho ficaria no grupo $A, o$ segundo no $B$, e assim até o grupo $H$. Após, uma primeira rodada de distribuição dos alunos nos grupos, reiniciou-se a distribuição a partir do aluno que estava na nona 
posição na lista de desempenho, de modo que este ficou no grupo $A$, o décimo no $B$ e assim por diante até que todos os alunos fossem distribuídos em todos os grupos. Optou-se por essa forma de distribuição para que houvesse uma interação entre alunos com diferentes tipos de desempenho, visando uma riqueza no debate das questões. Vale destacar que os participantes não conheciam o critério utilizado para a formação dos grupos.

O membro do grupo que obteve o maior escore foi selecionado pela pesquisadora para ser o observador do grupo. O observador teria o papel de registrar o processo de resolução do grupo de uma forma mais detalhada, de forma a somente observar e responder um questionário previamente elaborado pela pesquisadora referente às suas percepções sobre como ocorreu o processo de resolução das questões em seu grupo. Optou-se por selecionar o participante com o melhor desempenho para que ele não se comportasse como uma 'autoridade' que pudesse dominar, dirigir e/ou influenciar o grupo durante o processo de resolução dos problemas.

A atividade a ser desenvolvida nesse encontro foi semelhante à proposta individual, mas com um aumento no grau de dificuldade tendo em vista que os alunos já participaram de uma atividade semelhante. Essa atividade visava possibilitar uma comparação entre o processo de resolução de problemas de maneira individual e em grupo.

Em resumo, cada atividade de resolução de problema continha 6 questões conforme tabela 2:

Tabela 2: Quantitativo de questões resolvidas pelos participantes da pesquisa

\begin{tabular}{cccc}
\hline & Atividade 1 & Atividade 2 & $\begin{array}{c}\text { Atividade 3 } \\
\text { (grupo) }\end{array}$ \\
\hline Exercício & 2 & 2 & 2 \\
Problema Rotineiro & 2 & 2 & 2 \\
Problema não & 2 & 2 & 2 \\
Rotineiro & & & \\
\hline TOTAL & 6 & 6 & 6
\end{tabular}

Fonte: Elaborado pela pesquisadora 


\subsubsection{Observação}

Como os momentos descritos anteriormente foram mediados pessoalmente pela pesquisadora, a mesma esteve em contato direto com os participantes e esse era o propósito idealizado para essa pesquisa. Nessa ótica, vale destacar a importância do papel da observação para o desenvolvimento da pesquisa, pois essa "perpassa todas as etapas da pesquisa científica, no entanto, é no momento da constituição de dados que seu papel se torna mais evidente" (KRIPKA; BONOTTO; RICHTER, 2015, p. 235). Dessa forma, a pesquisadora pôde vivenciar o fenômeno junto à interação com os participantes e ter suas próprias percepções pelo contato com o fenômeno objeto da pesquisa, possibilitando uma aproximação com os participantes percebendo informações que não foram registradas de outras formas.

Sobre a observação, Jaccoud e Mayer (2008, p. 260) destacam que

de fato, a fenomenologia e a observação participante colocam em primeiro plano a dimensão subjetiva do indivíduo na sociedade, observando-o em sua 'concretude', e favorecendo a subjetividade por oposição ao estudo abstrato e o objetivo da realidade social.

Assim sendo, essa é uma forma de aproximar mais o pesquisador do fenômeno que se propôs a estudar, mais especificamente no caso da presente pesquisa poderá favorecer a dinâmica de observação dos participantes no ato da resolução de problemas percebendo como esses resolvem as atividades propostas, bem como as problemáticas, dilemas, dúvidas e considerações levantadas. Ainda sendo possível registrar diferentes percepções que não foram registradas nos protocolos.

\subsection{Procedimentos de Análise das Informações}

Com relação aos procedimentos de análise das informações, Creswell (2010, p. 209) destaca o papel do pesquisador na pesquisa qualitativa, pontuando que "os pesquisadores fazem uma interpretação do que enxergam, ouvem e entendem. Suas interpretações não podem ser separadas de suas origens, história, contextos e entendimentos anteriores", assim o pesquisador participa diretamente na interpretação das informações proporcionando um sentido mais amplo dos dados obtidos. 
Buscou-se ter uma diversidade de instrumentos de recolha das informações a fim de que se pudesse entender o fenômeno em profundidade, apesar da sua complexidade. Para isso, intentou-se realizar a análise das informações obtidas por meio de cada um dos instrumentos aplicados, relacionando-as. Esses dados foram analisados considerando o contexto em que estão inseridos, bem como foram analisados e interpretados simultaneamente visando maior riqueza da pesquisa (Gil, 2008).

Considerando que o objetivo da pesquisa é relacionado à análise das estratégias dos alunos, Cury (2008, p. 62) pontua que

\begin{abstract}
um texto matemático produzido por um aluno - uma demonstração de teorema, uma solução de um problema ou uma dissertação sobre determinado tópico - pode ser analisado, com base em procedimentos sistemáticos, para inferir conhecimentos sobre as formas com que aquele estudante construiu um determinado saber matemático.
\end{abstract}

Nessa ótica, a proposta da pesquisa não é apenas identificar se as respostas dos alunos correspondem às expectativas de alcance da resposta correta, mas de considerar as formas de resoluções desenvolvidas pelos mesmos, analisando o conhecimento matemático manifestado, bem como os conhecimentos que estão em processo de desenvolvimento, observando as dificuldades mais recorrentes e os obstáculos que foram demonstrados na proposição das soluções.

Cury (2008) enfatiza que a análise de produção escrita matemática, geralmente é realizada a partir da técnica de análise do conteúdo. Nesse sentido, seguiu-se perspectiva de análise proposta por Bardin (2004, p. 26), que apresenta os procedimentos para a referida tarefa como

um conjunto de técnicas que permitem a exploração e análise das informações de uma pesquisa. É por meio da Análise de Conteúdo que é possível retirar informações contidas num texto, interpretá-las podendo assim relacioná-las ao contexto em que se deu determinada produção. Esta forma de análise leva o pesquisador, depois de muito estudo, a criar categorias, agrupando unidades de análise semelhantes, fazendo inferências sempre que necessário e possível.

A análise da produção escrita foi realizada dialogando com a análise de conteúdo, dessa forma pôde-se refletir sobre o que e como o aluno pensou para resolver o problema, realizando inferências sobre as informações. Essas foram, então, analisadas em três etapas: a) pré-análise; b) exploração do material e, c) tratamento dos resultados (BARDIN, 2004). Na primeira fase (pré-análise), foi realizada uma leitura flutuante buscando conhecer as informações de uma forma mais geral, 
propondo hipóteses e identificando as informações de acordo com sua temática. Esses elementos orientaram a exploração do material.

Ainda nesse momento foi realizado a correção dos exercícios, analisando se as respostas obtidas estavam corretas ou não, e a forma como o aluno tinha realizado a resolução. Nessa etapa foi possível conhecer mais a fundo o processo de resolução que cada estudante tinha proposto.

Após se ter, na leitura prévia, um conhecimento mais geral das resoluções dos participantes, partiu-se para a exploração do material buscando definir as unidades de análise, guiando-se então para um recorte das informações de acordo com essas unidades, onde as produções escritas elaboradas pelos participantes foram agrupadas conforme suas relações. Para facilitar essa análise, procurou-se descrever a produção escrita de cada participante, explicitando a estratégia e o procedimento utilizado ao realizar a resolução do problema, agrupando os elementos semelhantes em categorias. Realizou-se também a contagem da frequência com que a referida categoria apareceu no decorrer dos dados.

Nesse contexto, as estratégias de resoluções apresentadas pelos participantes, registradas nos protocolos, foram categorizadas conforme suas maneiras de resolução, estratégias e conceitos utilizados visando analisar as formas que os mesmos propuseram as resoluções, observando também os questionamentos sugeridos por Silva e Buriasco (2005, p. 203):

“i) que caminhos os alunos escolhem para resolver problemas?;ii) que conhecimentos matemáticos utilizam?; iii) quais os erros que cometem e qual a natureza deles?; e iv) como utilizam as informações contidas nos enunciados das questões de Matemática?"

Cabe registrar que as autoras também propõem algumas indicações sobre a forma de se analisar as produções escritas dos alunos: se escolheu uma estratégia coerente/adequada para a resolução (e se conseguiu desenvolver esse procedimento corretamente), se fizeram uma proposta parcialmente correta (onde teve problema na resolução?) ou ainda se apenas apresentaram a proposta de resolução e não desenvolveram a mesma.

Por fim, no tratamento dos resultados, as informações foram analisadas descrevendo as categorias e as inferências alcançadas baseadas na interpretação das mesmas, relacionando os dados obtidos nos diversos instrumentos utilizados. 
Para fins de organização, a pesquisadora codificou os protocolos analisados. As atividades individuais possuem um código composto por uma letra seguida por 4 números. A letra representa quem registrou o dado, por exemplo o "E" se refere ao protocolo elaborado pelo estudante, já os números são formados da seguinte maneira: primeiro: atividade a que se refere (atividade 1 ou 2); segundo: número da questão; terceiro e quarto: código atribuído individualmente a cada estudante, sendo que cada participante da pesquisa recebeu um número entre 1 e 42 . Sendo assim, por exemplo, o código E1325 se refere ao protocolo produzido pelo aluno 25 na atividade 1 questão 3.

$\mathrm{Na}$ atividade em grupo, o código foi dividido em três tipos: dois dos dados registrados pelo observador e o registrado pelo grupo. O questionário do observador foi dividido em duas partes: uma composta por 7 perguntas referente a suas percepções com relação ao trabalho desenvolvido pelo grupo no ato da resolução dos problemas e outra onde registraria o que observou do processo de resolução de cada uma das questões que o grupo resolveu. Sendo assim, o código foi desenvolvido com duas letras, um número e outra letra: a primeira letra se refere ao sujeito que registrou a atividade, a segunda se era um registro referente as considerações relativas a uma pergunta ou a uma questão que foi resolvida, o número é referente a pergunta ou a questão; e a terceira letra se refere a letra do grupo. Por exemplo: o código OP1H se refere ao protocolo obtido pelo observador do grupo $\mathrm{H}$ referente a pergunta 1; já o $\mathrm{OQ} 1 \mathrm{H}$ se refere ao protocolo obtido pelo observador do grupo $\mathrm{H}$ referente a questão 1.

O protocolo registrado pelo grupo é formado pela letra $G$ referindo a atividade em grupo, seguida do número da questão e uma última letra determinando o grupo que produziu o protocolo, como por exemplo, o código G1F se refere a questão 1 da atividade do grupo F. Com relação aos dados do inventário foi atribuído o seguinte código: a letra I, o número da questão e o número atribuído ao participante, sendo 11021 referente aos dados no inventário do aluno 21 na questão 10.

Vale destacar ainda que os dados serão apresentados também em formato de tabelas, protocolos dos alunos e demais elementos ilustrativos descrevendo a recorrência das informações como recurso da estatística descritiva buscando facilitar a leitura das informações a partir da ilustração e agrupamentos mais concisos. 


\section{CAPÍTULO 4: RESULTADOS E ANÁLISES}

Das 18 questões aplicadas aos alunos no decorrer das atividades propostas, tanto em atividades individuais quanto em grupo, foram selecionadas 9 questões com vistas a se proceder uma análise mais aprofundada nesta dissertação, sendo 3 questões ( 1 exercício, 1 problema rotineiro e 1 problema não rotineiro) de cada tipo de atividade 'distinta'. Apresenta-se as tabelas 3, 4 e 5 referente a correção das atividades individuais e em grupo das questões selecionadas para análise.

Tabela 3: Desempenho dos participantes nos exercícios

\begin{tabular}{cccc}
\hline & Atividade 1 & Atividade 2 & Atividade 3 (grupo) \\
\hline Correta & $23(63,9 \%)$ & $16(51,6 \%)$ & $6(75 \%)$ \\
$\begin{array}{c}\text { Parcialmente } \\
\text { Correta }\end{array}$ & $0(0 \%)$ & $3(9,7 \%)$ & $0(0 \%)$ \\
Incorreta & $8(22,2 \%)$ & $8(25,8 \%)$ & $1(12,5 \%)$ \\
Em Branco & $5(13,9 \%)$ & $4(12,9 \%)$ & $1(12,5 \%)$ \\
\hline TOTAL & $36(100 \%)$ & $31(100 \%)$ & $8(100 \%)$
\end{tabular}

Fonte: Elaborado pela pesquisadora

Tabela 4: Desempenho dos participantes nos problemas rotineiros

\begin{tabular}{cccc}
\hline & Atividade 1 & Atividade 2 & Atividade 3 (grupo) \\
\hline Correta & $14(38,9 \%)$ & $9(29 \%)$ & $7(87,5 \%)$ \\
Parcialmente & $2(5,6 \%)$ & $3(9,7 \%)$ & $0(0 \%)$ \\
Correta & $16(44,4 \%)$ & $16(51,6 \%)$ & $1(12,5 \%)$ \\
Incorreta & $4(11,1 \%)$ & $3(9,7 \%)$ & $0(0 \%)$ \\
Em Branco & $36(100 \%)$ & $31(100 \%)$ & $8(100 \%)$ \\
\hline TOTAL & & &
\end{tabular}

Fonte: Elaborado pela pesquisadora 
Tabela 5: Desempenho dos participantes nos problemas não rotineiros

\begin{tabular}{cccc}
\hline & Atividade 1 & Atividade 2 & Atividade 3 (grupo) \\
\hline Correta & $2(5,6 \%)$ & $5(16,1 \%)$ & $1(12,5 \%)$ \\
Parcialmente & $3(8,3 \%)$ & $1(3,2 \%)$ & $1(12,5 \%)$ \\
Correta & $23(63,9 \%)$ & $16(51,7 \%)$ & $6(75 \%)$ \\
Incorreta & $8(22,2 \%)$ & $9(29 \%)$ & $0(\%)$ \\
Em Branco & $36(100 \%)$ & $31(100 \%)$ & $8(100 \%)$ \\
\hline TOTAL & & &
\end{tabular}

Fonte: Elaborado pela pesquisadora

\subsection{Exercícios}

\subsubsection{Primeira Atividade Individual}

$\mathrm{Na}$ primeira atividade individual foi proposto o seguinte exercício a ser resolvido:

$$
\begin{gathered}
\text { Determine o valor de } X: \\
\frac{8}{6}=\frac{X}{15}
\end{gathered}
$$

Dos 23 que acertaram 22 resolveram exatamente da mesma forma, aplicando a propriedade fundamental das proporções, que diz que em toda proporção, o produto dos meios é igual ao produto dos extremos (de forma "simples", realizando uma multiplicação cruzada).

Figura 3: Produção escrita E1120.

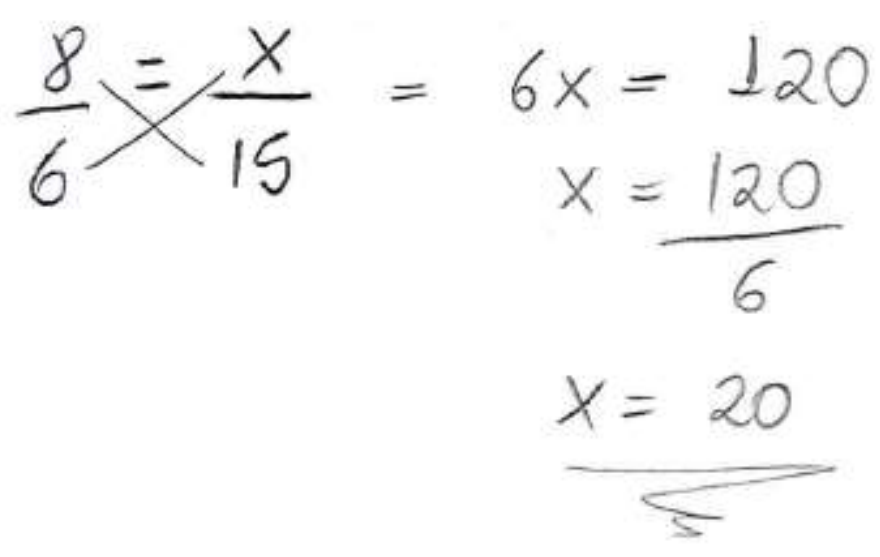


Fonte: Arquivo pessoal da pesquisadora

A forma de resolução evidencia uma padronização no procedimento de cálculo, típico em situações que se caracterizam como um exercício, visto que apenas um dos alunos propôs outra forma de resolução para essa atividade.

Figura 4: Produção escrita E1123.

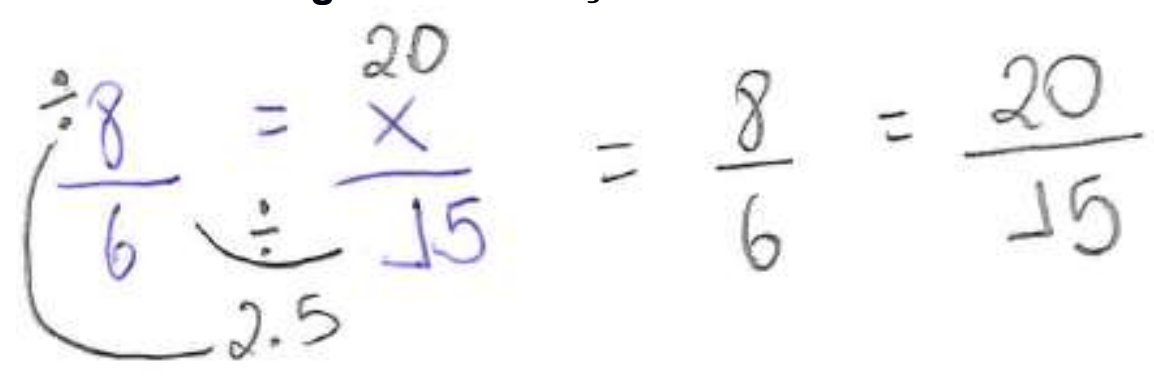

Fonte: Arquivo pessoal da pesquisadora

Esse aluno percebeu a relação proporcional entre as frações determinando a razão entre elas, observando que o 15 e o 6 estavam relacionados ao se dividir 15 por 6 determinando 2,5 como a razão - dessa forma relacionou também o valor que $x$ deveria ter com o 8 e a razão descoberta, encontrando o valor de $20\left(8^{\star} 2,5\right)$. Ele demonstrou perceber essa relação entre as duas frações e o papel da razão nessa proporção. Esse estudante demonstrou um entendimento acerca do conceito de proporcionalidade ao perceber a equivalência entre essas frações apresentadas.

Oito alunos não produziram a resposta correta para a questão, tendo cada um procedido de uma forma específica, ou seja, não houve repetição de padrões e/ou estratégias. Desses alunos, 3 aplicaram a propriedade fundamental das proporções, demonstrando que lembravam algo sobre o algoritmo geralmente usado para a resolução desse tipo de questão, mas após a aplicação do procedimento, equivocaram-se na sequência das ações, como evidenciado pelo aluno 38, que "multiplicou cruzado" realizando a divisão dos valores que encontrou (6/120). O aluno 21 "multiplicou cruzado" e multiplicou os valores encontrado $\left(6 x^{*} 120=720 x\right)$; e o aluno 05 multiplicou o 6 com o $x$ e dividiu o 15 pelo 8 (6x=15/8).

O participante 17 fez a divisão da primeira fração e multiplicação dos números da segunda $(1,33=15 \mathrm{x})$ e resolveu a equação gerada por esses resultados; já o aluno 40 multiplicou os numeradores e somou os denominadores $(8 x / 21)$; e, os últimos 3 
que erraram não demonstraram uso de uma estratégia bem estruturada em vista de se proceder a resolução do exercício, registrando raciocínios não compreensíveis, como:

Figura 5: Produção escrita E1110.

Fonte: Arquivo pessoal da pesquisadora

\subsubsection{Segunda Atividade Individual}

O exercício proposto na segunda atividade foi o seguinte:

Determine os valores de $x$ e y na seguinte proporção

$$
\frac{x}{8}=3=\frac{6}{y}
$$

Dos 31 alunos que responderam essa questão, 16 chegaram à resposta correta, sendo possível separar as estratégias utilizadas por esses estudantes em duas categorias. Na primeira, 3 alunos não realizaram cálculos para encontrar os valores de x e y, afirmando que utilizaram de lógica para encontrar as soluções. Esses alunos demostraram um certo amadurecimento em relação aos conceitos de razão e proporção, percebendo que o resultado das divisões dessas frações deveria ser igual a 3 , encontrando assim os valores de x e y "usando a lógica", conforme pode ser visualizado na figura 6 : 


\section{Figura 6: Produção escrita E2107.}

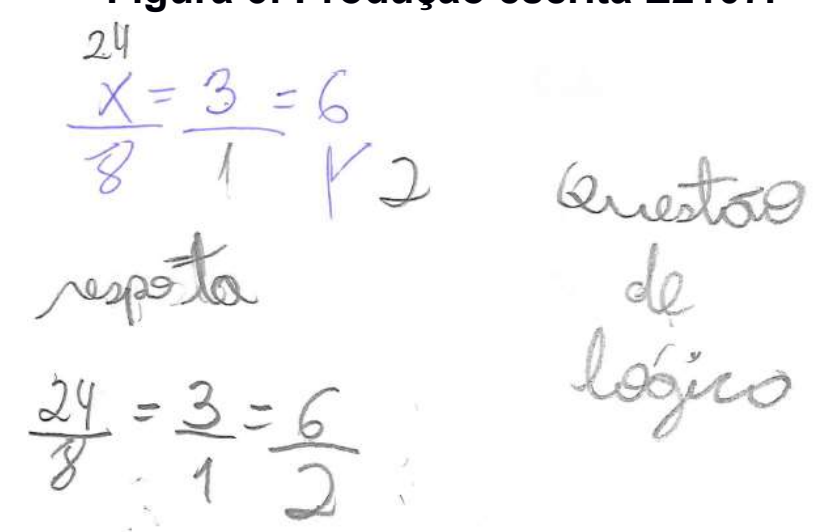

Fonte: Arquivo pessoal da pesquisadora

Cabe adiantar que embora esses 3 estudantes aparentemente tenham demonstrado capacidade de maior abstração e domínio dos conceitos de razão e proporção em exercícios, os mesmos não tiveram os melhores rendimentos nos problemas não rotineiros. Dos 4 problemas realizados individualmente analisados nessa pesquisa, dois acertaram um problema rotineiro e um acertou os dois problemas dessa natureza. Nenhum desses alunos acertou um problema não rotineiro.

Já na segunda categoria, 13 alunos resolveram a questão utilizando a propriedade fundamental das proporções:

\section{Figura 7: Produção escrita E2117.}
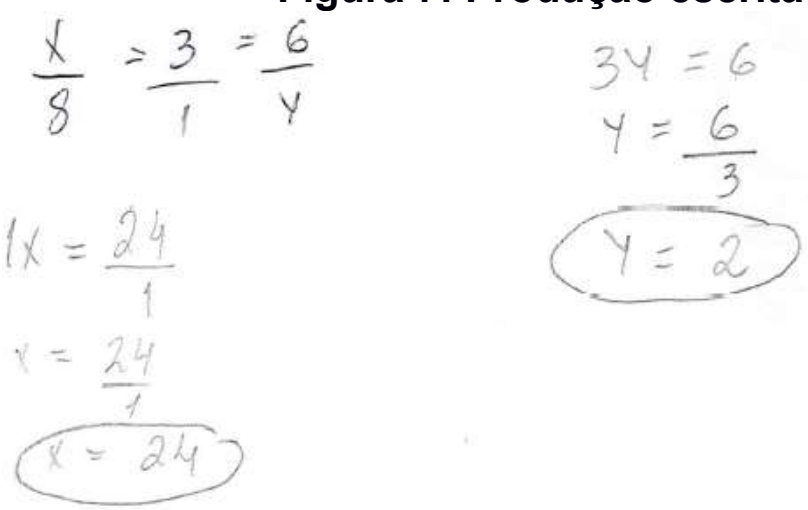

Fonte: Arquivo pessoal da pesquisadora 
Desses, 12 relacionaram a fração que tinha $x$ com o número 3 , encontrando 0 valor de $\mathrm{x}$, e depois relacionaram a fração que tinha o y também com o número 3 , realizando as operações para encontrar os valores de $\mathrm{x}$ e $\mathrm{y}$ com o valor que estava ao lado. Apenas o aluno 24 encontrou o valor de $x$, substituindo-o em seguida na fração para calcular o valor de y.

Uma curiosidade dentre as recorrências encontradas refere-se ao procedimento utilizado por 10 dos 16 alunos que acertaram essa questão. Eles sentiram a necessidade de registrar o número 1 como denominador da fração de numerador 3. Esse fato pode sugerir que esses alunos têm a necessidade de caracterizar um número inteiro como uma representação fracionária para proceder os cálculos requeridos no exercício, indicando que precisam transformar todos os valores em frações (possuindo um numerador e um denominador) para em seguida resolver o exercício. Isso pode estar relacionado a uma estereotipia apreendida ainda nos primeiros anos escolares e que ficou cristalizada na mente dos estudantes. Ressaltase que não há incorreção no procedimento utilizado, entretanto, esperava-se que no final do ensino médio os estudantes pudessem realizar essas operações a partir de uma representação mental.

A questão foi considerada parcialmente correta quando o aluno acertou apenas uma das respostas, isto é, encontrou apenas o valor de x ou apenas o valor de y. Três alunos tiveram uma resposta parcialmente correta, onde dois acertaram o resultado de $x$ e um acertou o resultado de $y$. Vale a pena destacar que esses 3 alunos acertaram pelo menos um dos dois exercícios da atividade individual 1. Esses alunos realizaram dois tipos de operações diferentes para resolver situações análogas, indicando que provavelmente eles estavam inseguros em relação ao procedimento correto para resolver (multiplicar numerador com numerador ou multiplicar cruzado?) sendo que optaram por realizar ambas as operações. 
Figura 8: Produção escrita E2116.

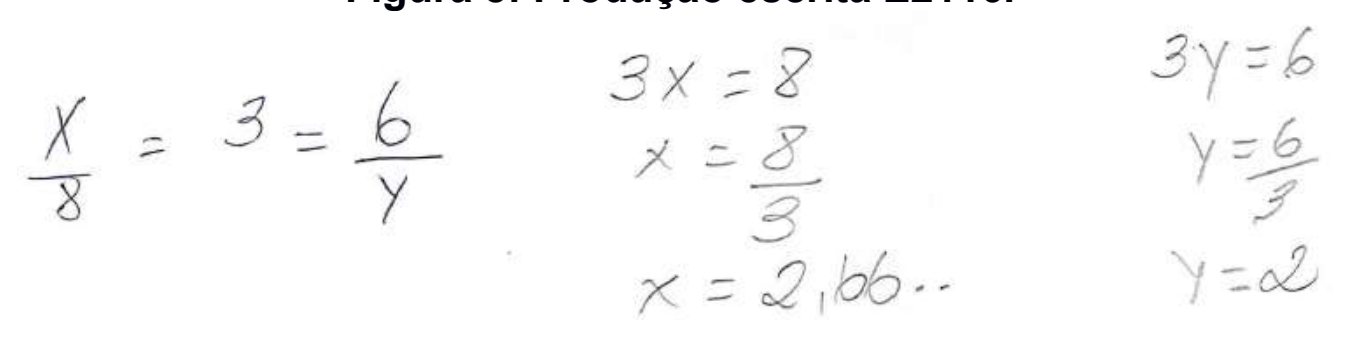

Fonte: Arquivo pessoal da pesquisadora

Para encontrar o valor de y, o aluno 16 efetuou uma multiplicação cruzada, demonstrando que conhece o algoritmo da regra de três simples e diretamente proporcional, no entanto por algum motivo não realizou o mesmo procedimento para encontrar o valor de $\mathrm{x}$, multiplicando os denominadores e igualando o produto a 8 , não obtendo dessa forma o valor correto de $\mathrm{x}$.

Esse tipo de resolução evidencia um provável processo de memorização de fórmulas e algoritmos sem que os alunos tenham compreendido os conceitos envolvidos. É importante que o aluno saiba aplicar adequadamente a propriedade fundamental das proporções, consciente do motivo de calcular de uma forma e não de outra, questionando o significado de "multiplicar de cima com de cima" ou "multiplicar cruzado", qual a diferença dessas formas de resolução? ou o que cada uma delas significa? O problema não é aplicar um procedimento padronizado, mas não saber o motivo de estar fazendo dessa ou daquela maneira.

Dos 8 participantes que não produziram uma resposta correta ou parcialmente correta, 3 não conseguiram chegar a uma resposta. Embora tenham começado a esboçar suas resoluções, não deram prosseguimento, tendo um enfatizado explicitamente: "essa eu não sei resolver" (E2530). Os demais apresentaram respostas diferentes.

O participante 27 resolveu o exercício representando todas as frações com o mesmo denominador, a partir do cálculo do mínimo múltiplo comum - MMC, desconsiderando o valor de y. Provavelmente ele resolveu dessa forma por ter evocado de suas memórias algumas recomendações acerca das operações com frações, entretanto, essa forma de resolução não foi a mais apropriada para a resolução do exercício proposto, revelando um possível erro conceitual. Infelizmente o aluno não registrou os motivos para a escolha do procedimento utilizado, deixando 
assim, uma lacuna na investigação e que carecerá de estudos futuros para a sua explicação.

Um participante, em seus comentários registrou: "somei os valores de cima e os debaixo" (E2140), assim, realizou a soma dos valores dos numeradores e depois os dos denominadores, apresentando $x+3+6=9 x$. Além do raciocínio proposto para a resolução estar incorreto, a soma realizada também está errada pois a soma das parcelas dos numeradores é $9+x$, para ele chegar a esse resultado de $9 x$, o mesmo deveria ter somado os números e multiplicado por $\mathrm{x}$, e nos valores do denominador ele considerou $8+y=8 y$, desconsiderando o valor do denominador do número 3 . Além de demonstrar uma fragilidade em conceitos relacionados a operações com monômios, o aluno também não conseguiu perceber o número 3 como uma fração de denominador 1 .

Figura 9: Produção escrita E2140.

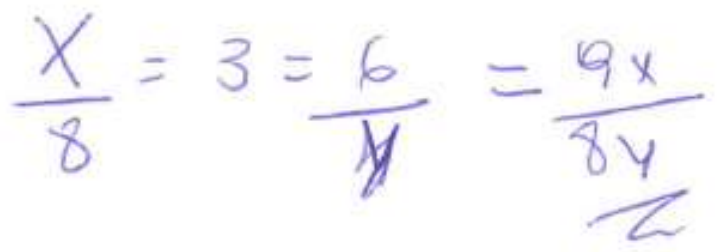

Fonte: Arquivo pessoal da pesquisadora

Além dos erros já destacados, o referido aluno demonstrou não ter compreendido o que o exercício solicitava, tendo em vista que no enunciado foi requerida a determinação dos valores de $\mathrm{x}$ e de $\mathrm{y}$, demonstrando uma falta de criticidade com relação aos resultados obtidos como resposta.

\subsubsection{Atividade em Grupo}

Já na $3^{\circ}$ atividade, foi proposto o seguinte exercício a ser resolvido pelo grupo:

Determine os valores de $\mathrm{x}$ e y na seguinte proporção

$$
\frac{24}{X}=\frac{Y}{8}=\frac{12}{3} \text {. }
$$


Dos 8 grupos, 6 acertaram o exercício, um não obteve o resultado correto e um deixou em branco. Dos grupos que acertaram, 5 resolveram por meio propriedade fundamental das proporções. Quanto à ordem para se encontrar os valores de x e de $y$, pode-se observar 2 tipos de resolução:

Os grupos (A, D, F e G) primeiramente relacionaram a segunda e terceira razões para encontrar o valor de y, e depois substituíram o valor de y para relacionar essa razão à primeira para descobrir o valor de $\mathrm{x}$.

Figura 10: Produção escrita G1F.
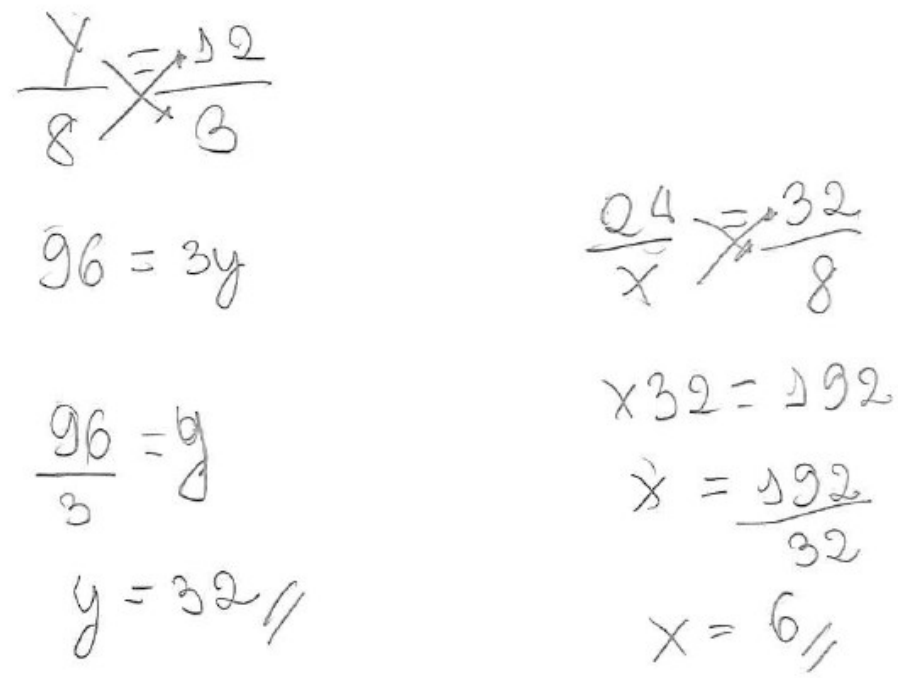

Fonte: Arquivo pessoal da pesquisadora

Pode-se observar que esses grupos, tanto para descobrir as duas incógnitas relacionaram as frações que estavam lado a lado, de forma semelhante ao observado em grande parte dos alunos que resolveram o exercício da atividade 2. 0 processo de resolução desses grupos foram iguais realizando exatamente os mesmos procedimentos para obter a resposta, demonstrando certa padronização no processo de resolução, da mesma forma como observado nas atividades individuais. Essa característica pode ser decorrente a uma reprodução da notação realizada pelo professor em sala de aula no momento de resolução desse tipo de exercício.

Já os grupos B e H relacionaram a fração que tinha $\mathrm{x}$ com a última fração, bem como a que tinha y também com a última. Vale destacar que o grupo $\mathrm{H}$ foi o único que 
registrou que a última fração era um número inteiro realizando os cálculos utilizando esse valor.

Figura 11: Produção escrita G1H.
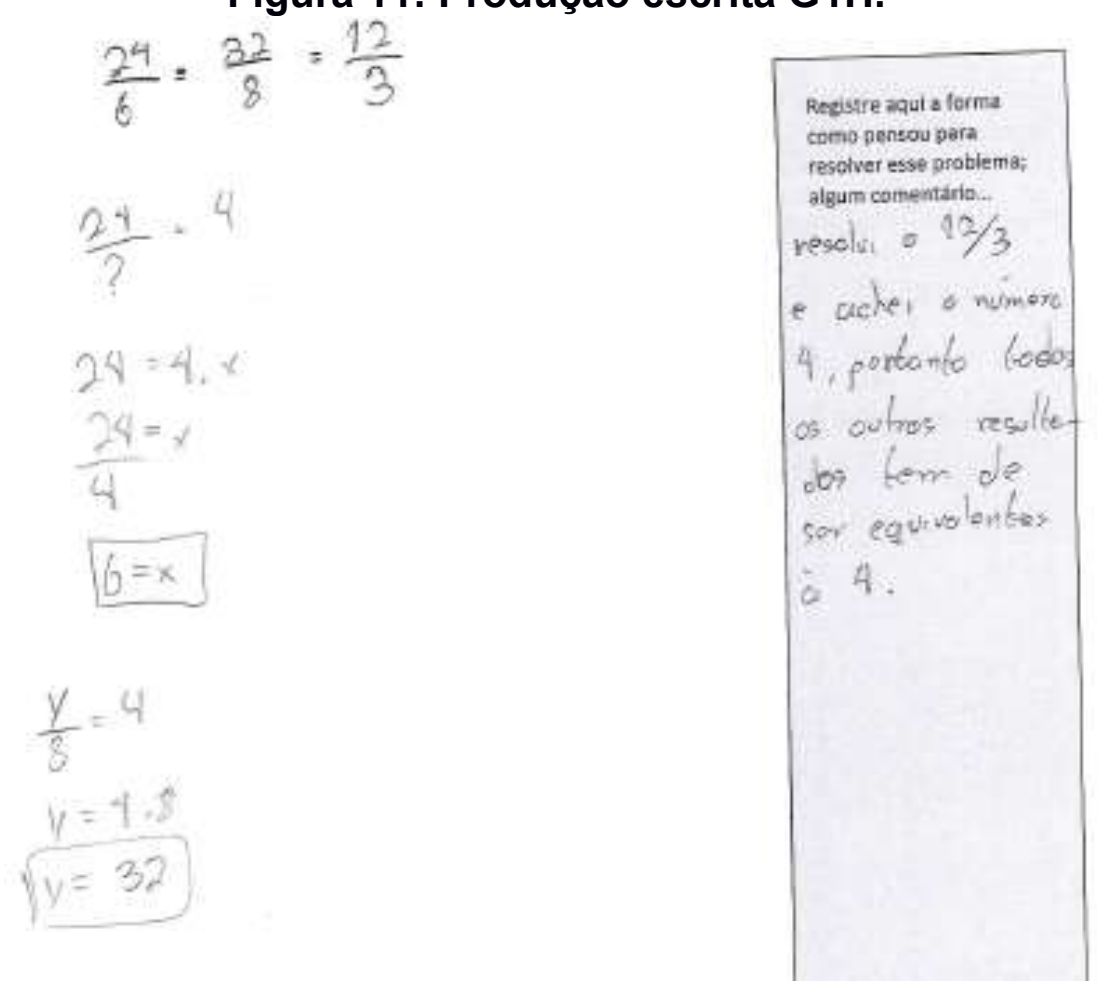

Fonte: Arquivo pessoal da pesquisadora

Esses participantes foram os únicos a perceber que todas as frações deveriam ser equivalentes a 4, dessa forma o resultado da divisão entre o numerador e o denominar deveria ser igual a 4 - parecendo transparecer que para esses, os números indicados nos resultados detinham esse significado. Vale destacar que esse grupo foi o único a acertar todas as questões propostas nessa atividade.

Apenas o grupo $C$ não acertou a questão, o mesmo cometeu um equívoco na montagem da razão a ser resolvida considerando 8y e não y/8: 
Figura 12: Produção escrita G1C.

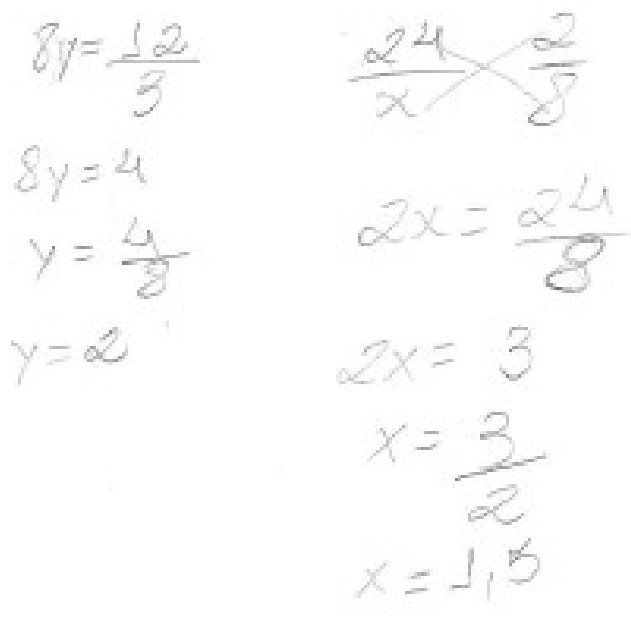

Fonte: Arquivo pessoal da pesquisadora

Para determinar o valor de $\mathrm{x}$, utilizaram o valor de $\mathrm{y}$, que foi calculado de maneira incorreta, levando-os consequentemente a encontrar um valor diverso para $x$. Além de ter utilizado um valor incorreto para y, eles também cometeram outro equívoco: ao invés de multiplicar 24 por 8 , como fizeram com 2 e x, eles dividiram esses valores.

Pode-se perceber que os alunos utilizaram diferentes procedimentos de cálculo para determinar os valores de $x$ e de $y$, demonstrando que não tinham certeza de qual seria a forma certa para resolver, assim como observado em algumas produções dos alunos na atividade individual 2. É possível perceber esse indício, pois se caso soubessem realmente como proceder, não haveriam estruturado duas maneiras diferentes para tal, demonstrando assim uma fragilidade no conhecimento do algoritmo geralmente relacionado a resolução de questões que envolvem regra de 3 .

Para-se determinar o valor de y eles realizaram a seguinte divisão: 4/8 obtendo o resultado igual a 2. Vale destacar que todos os grupos tinham calculadora a disposição para ser utilizada, mas apesar disso os alunos trocaram a ordem da divisão realizando 8/4. Como as outras divisões realizadas pelo grupo em outros exercícios foram feitas corretamente, pode-se inferir que eles cometeram um equívoco ao realizar essa divisão, mas que provavelmente sabem como se resolver $4 / 8$.

O observador desse grupo registrou que "foram feitas algumas contas aleatórias... as pessoas duvidaram das respostas" (OQ1C), reforçando a ideia de que 
o conceito de razão e proporção não foi bem construído por esses alunos. Dos 3 participantes do grupo, o participante 16 e o 36 acertaram uma questão cada quando fizeram esse tipo de exercício individualmente, já o participante 21 deixou ambas as atividades em branco. Apesar de dois participantes do grupo terem acertado anteriormente um exercício individual, e após o momento de feedback onde foi brevemente abordado a forma de resolução da regra de 3 , o grupo não conseguiu obter o resultado correto demonstrando certa insegurança dos participantes com relação a esse processo de resolução.

Vale destacar ainda que, esse foi o único grupo que não obteve êxito em alguma das questões da atividade em grupo. Ao se analisar os dados do inventário "Minhas atitudes em relação a matemática" desses participantes que estavam resolvendo as questões, pode-se perceber que os mesmos declaravam ter um baixo rendimento com relação a matemática bem como pouca motivação para atividades relacionadas a essa disciplina.

$\mathrm{O}$ único grupo que deixou a atividade em branco foi o grupo $\mathrm{E}$.

Apesar do número de alunos que tiveram a resposta incorreta nas atividades individuais 1 e 2 serem o mesmo (8 alunos em cada), apenas 3 (27, 38 e 40) não obtiveram o resultado correto em ambas atividades, os demais erraram apenas a primeira ou a segunda.

Com esse exercício pode-se perceber que grande parte dos participantes da pesquisa sabe como resolver questões desse tipo que abordam conhecimentos relacionados a razão e proporção. A maior parte dos participantes que acertaram essas questões optaram por utilizar a propriedade fundamental das proporções (22 dos 23 que acertaram a primeira atividade, 13 dos 16 da segunda e todos os 6 grupos) sendo a principal forma de resolução adotada pelos participantes.

\subsection{Problemas Rotineiros}




\subsubsection{Primeira Atividade Individual}

Na primeira atividade individual foi proposto um problema rotineiro extraído do exame do Pisa realizado em 2012. O problema era:

A estação espacial Mir permaneceu em órbita por 15 anos e deu cerca de 86500 voltas em torno da Terra, durante o tempo em que esteve no espaço. A permanência mais longa de um astronauta na Mir foi de, aproximadamente, 680 dias. Aproximadamente, quantas voltas este astronauta deu ao redor da Terra?

Conforme apresentado na Tabela 4, 14 alunos responderam corretamente esse problema. Ressalta-se que o enunciado não definia se era para considerar uma determinada quantidade de dias para o ano, buscando avaliar conhecimentos básicos do sujeito solucionador, o que resultou no empreendimento de algumas soluções empregando 365 dias e outras considerando 360 dias. As resoluções foram analisadas considerando o valor escolhido pelo aluno, uma vez que buscou-se valorizar a premissa elencada inicialmente pelo estudante na construção de sua estratégia de resolução. Vale destacar que por esse motivo, e pelo fato de se estar trabalhando com arredondamentos e números aproximados, os valores das respostas corretas não foram exatamente os mesmos em sua maioria, mas sim valores aproximados.

As formas de resolução dos que alcançaram a resposta esperada foram categorizadas em dois grandes grupos: os que efetuaram multiplicações e divisões, de maneiras isoladas para chegar ao resultado final (9 alunos) e os que utilizaram regra de 3 (5 alunos).

Grupo 1:

Dos que acertaram, 9 resolveram por divisão e multiplicação podendo ser divididos em 3 subgrupos. No primeiro subgrupo 3 participantes descobriram quantas voltas a estação dava por ano, mês e dia, dividindo 86.500 primeiramente por 15 , depois por 12 e finalmente por 30. Após isso, estabeleceram a relação de 
correspondência entre 680 dias e 1 ano e 320 dias ou em aproximadamente 1 ano e 11 meses, somando os quantitativos referentes a essas partes:

Figura 13: Produção escrita E1234.

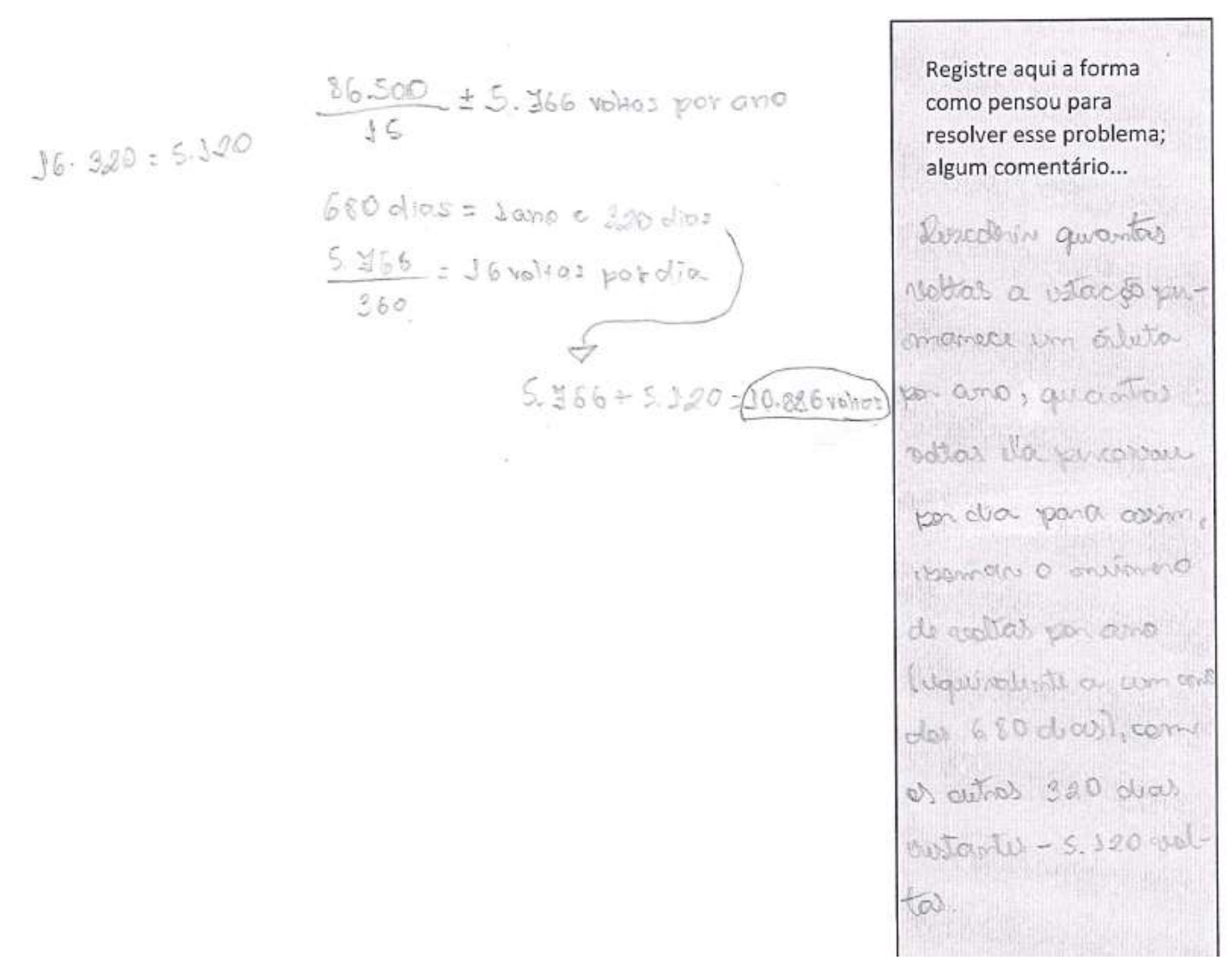

Fonte: Arquivo pessoal da pesquisadora

Outros 5 alunos descobriram quantos dias tem em 15 anos multiplicando esse valor por 360 ou 365; dividiram 86500 por esse valor para encontrar a quantidade de voltas por dia e por fim multiplicaram a quantidade de voltas por dia por 680 : 
Figura 14: Produção escrita E1224.
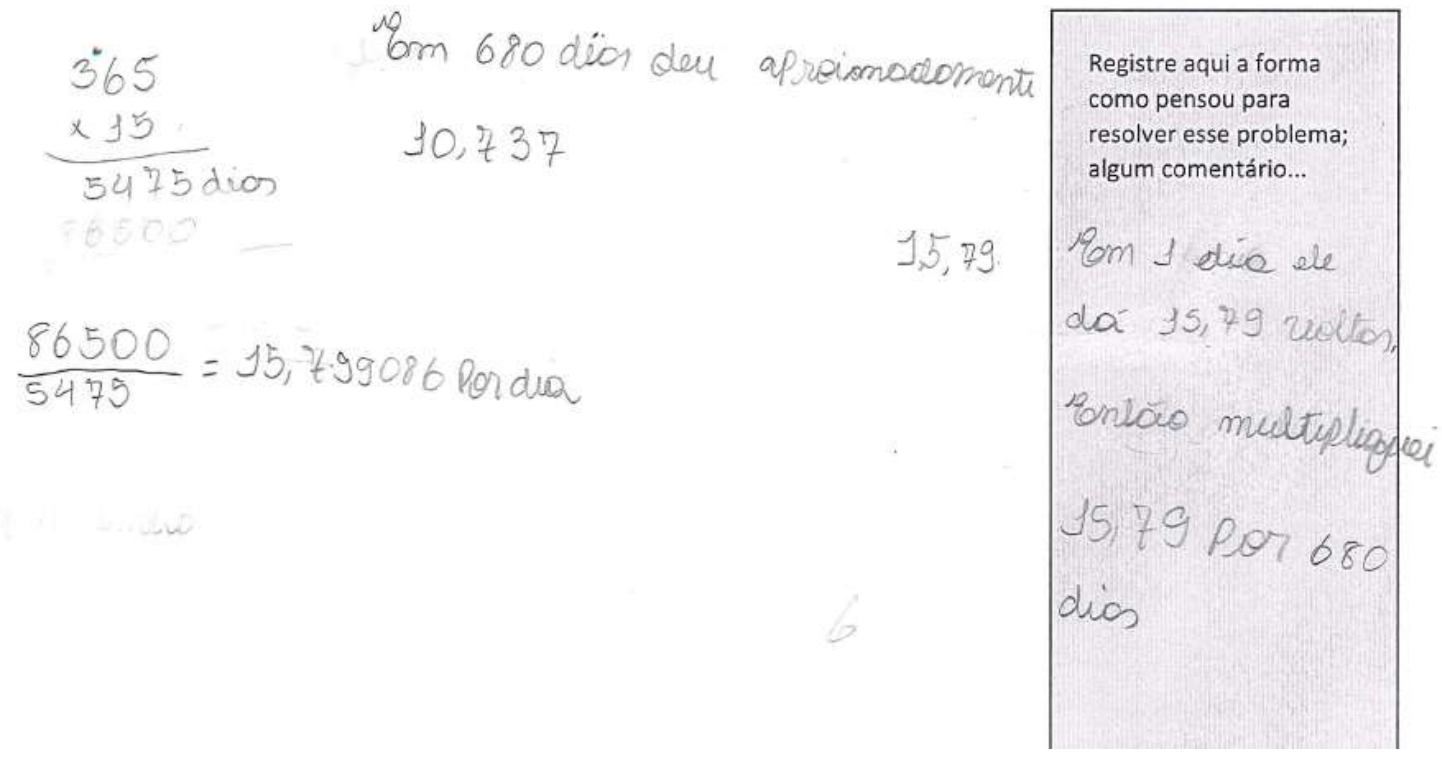

Fonte: Arquivo pessoal da pesquisadora

Interessante notar que um aluno, ao calcular a quantidade de dias correspondentes a 15 anos, levou em consideração as possibilidades de dias que poderiam haver nesse período, sem levar em conta os anos bissextos, tendo 3 ou 4 anos bissextos no período. Após obter os totais de dias, o aluno realizou a divisão do total de voltas por cada um dos quantitativos de dias que poderia haver nesse período e percebeu que todos se aproximavam de 15,7 por dia utilizando esse valor para multiplicar por 680. Registra-se que nesse caso não realizou o arredondamento corretamente, pois o correto seria 15,8 , no entanto, esse fator não foi determinante para que a questão fosse considerada incorreta: 
Figura 15: Produção escrita E1212.

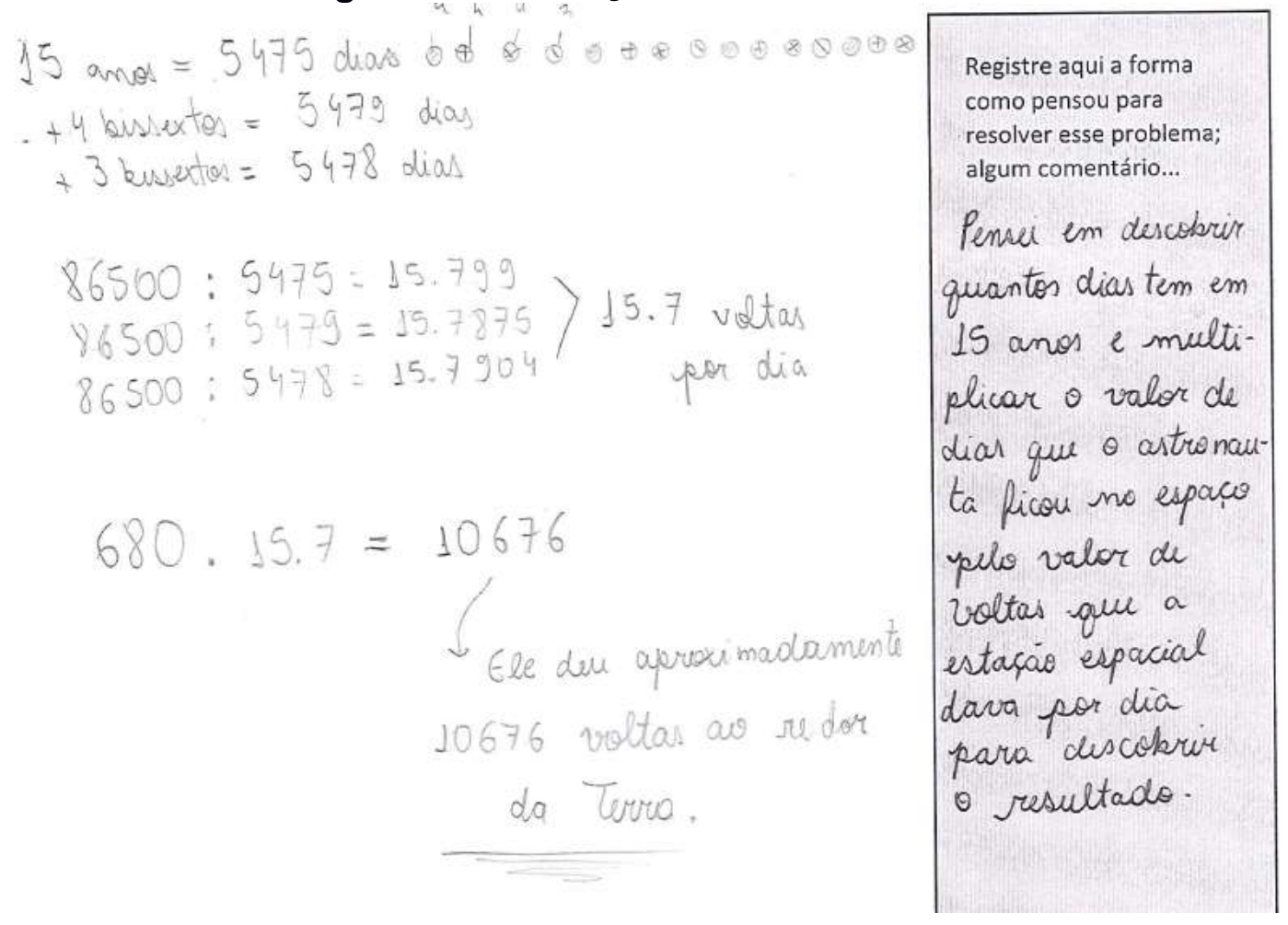

Fonte: Arquivo pessoal da pesquisadora

Outro aluno também destacou esse fato de se considerar os anos bissextos ou não em sua conta, mostrando assim uma criticidade com relação ao enunciado do problema apresentado. Fato como esse sinaliza que o problema foi internalizado por esses estudantes que, mais do que meramente buscar realizar algoritmos para a solução da tarefa, foram conduzidos à reflexões a partir de variáveis não apresentadas explicitamente no problema.

O último subgrupo, composto por apenas um participante, se caracteriza por ter transformado os dados para ano. Ele dividiu 86500 por 15 para encontrar a quantidade de voltas por ano; transformou 680 dias em anos dividindo por 365 sendo igual a aproximadamente 1,9 anos; e multiplicou os dois valores.

\section{Grupo 2:}

Dos 5 que utilizaram regra de 3 , apenas 1 transformou os 680 dias em anos, enquanto os demais utilizaram diretamente a informação em dias. 
Figura 16: Produção escrita E1237.

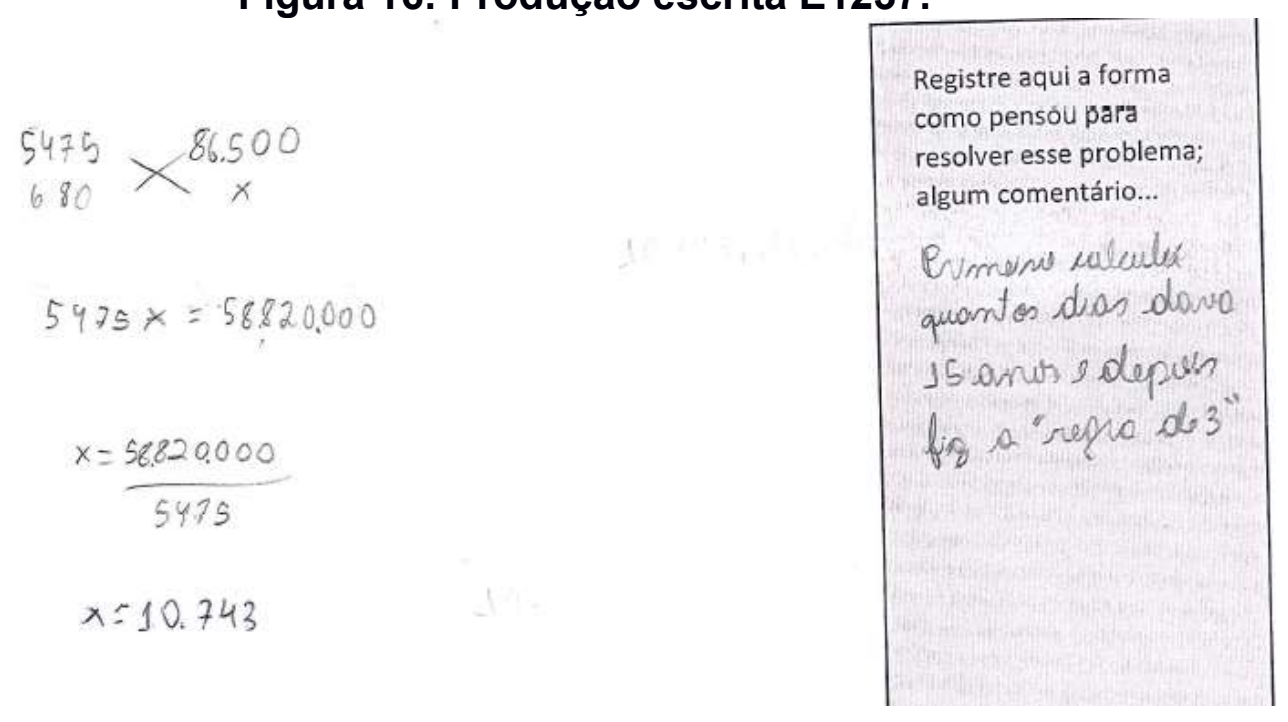

Fonte: Arquivo pessoal da pesquisadora

Figura 17: Produção escrita E1241.
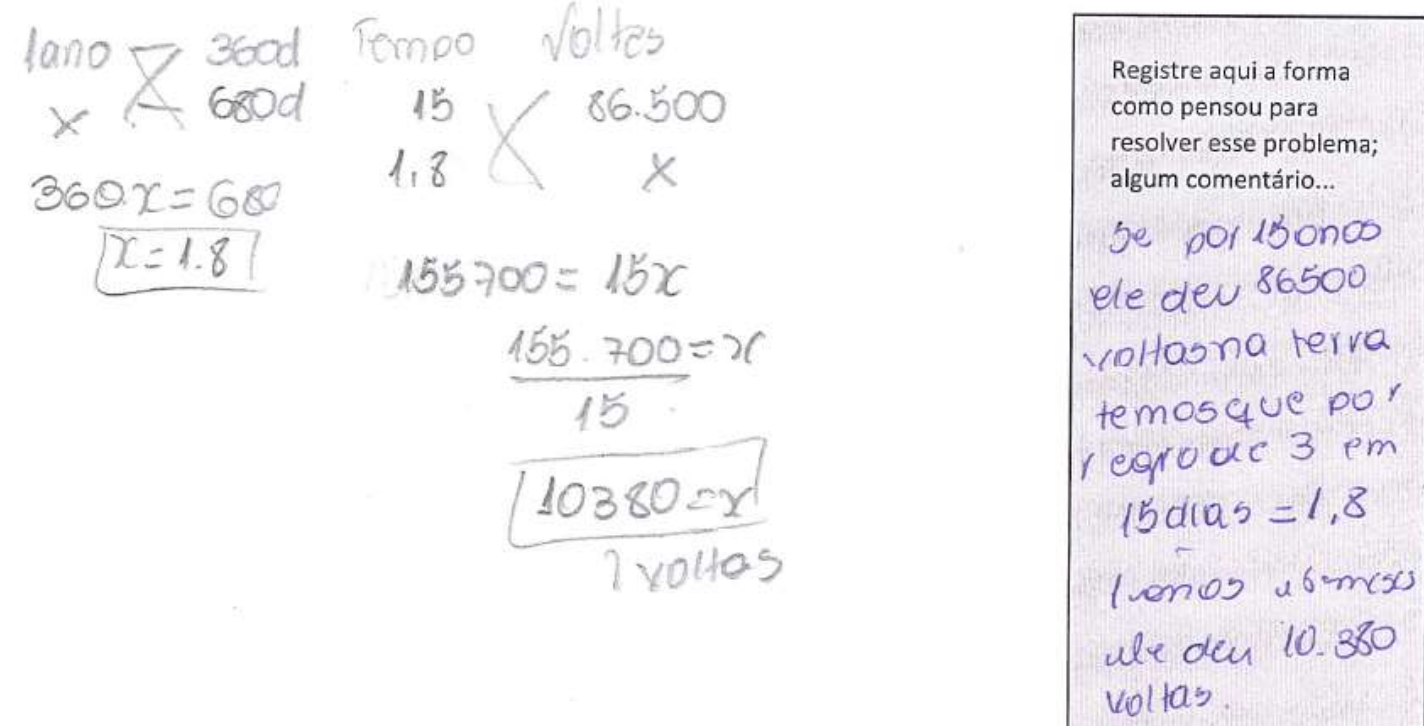

Fonte: Arquivo pessoal da pesquisadora

Vale destacar que esses alunos que optaram por resolver o problema utilizando uma regra de três conseguiram relacionar corretamente as grandezas envolvidas no problema obtendo assim um resultado correto.

Dos 2 alunos que obtiveram a resposta parcialmente correta, pode-se perceber que eles conseguiram interpretar corretamente a questão bem como os dados fornecidos e desenvolveram um raciocínio apropriado para se obter o resultado, mas 
consideraram 680 dias como aproximadamente 2 anos. Pode-se justificar essa aproximação se considerarmos sob uma reflexão mais abrangente e aplicada no cotidiano, onde 1 ano e 11 meses são quase 2 anos. Contudo, se compreendermos uma aproximação matemática mais precisa, o certo seria ter considerado 1,9 anos ou aproximadamente 1 ano e 11 meses.

Dentre esses alunos, cabe destacar que um realizou multiplicações e divisões a partir dos dados informados no enunciado e o outro por regra de 3 . Além disso, um deles organizou e executou corretamente a regra de 3 , equivocando-se na finalização da última operação, obtendo um resultado incorreto na operação 173.000/15.

As formas de resolução dos 16 participantes que não alcançaram a resposta correta foram bastante diversas, havendo apenas 2 resultados iguais: 127 (resultado de 86.500/680) e 10.200 (resultado de 680*15). Dos demais, cada um produziu uma resposta diferente em relação aos demais participantes, sendo que as respostas variaram de 0,0000918 a 12.975 .500 . O participante 30 que obteve o resultado de 12.975.500 multiplicou os dois primeiros valores que aparecem $\left(15^{\star} 86.500\right)$ demonstrando não ter compreendido o contexto do problema, além de ignorar os demais dados. Se o aluno tivesse interpretado corretamente, entendendo seu contexto, perceberia que a resposta que encontrou pareceria absurda pois a quantidade de voltas em menos de dois anos tem que ser menor do que o número de voltas de 15 anos. Isso sugere que para o estudante tratava-se de apenas um número, sem significado ou necessidade de coerência.

Em casos como esse, o docente poderia intervir provocando o aluno a se questionar que se em 15 anos a estação dá 86.500 voltas em torno da terra, em menos de 2 anos (680 dias) a estação teria que dar um número menor de voltas e não muito maior como propõe a resposta. Pensamento análogo pode ser aplicado ao participante 06 que obteve a resposta 0,0000918 (resultado da operação $\left.15^{\star} 360 / 865000 / 680\right)$, se em quase 2 anos ele deu 0,0000918 voltas em 15 anos ele não daria 86.500 voltas.

O PISA (BRASIL, 2016) também destaca a importância dessa interpretação, aplicação e avaliação dos resultados matemáticos, ressaltando a relevância em se verificar se aquele resultado obtido é aceitável para o contexto proposto pela questão, relacionando essas características ao letramento matemático. 
Sendo assim vale destacar a importância de se ter criticidade sobre os dados obtidos no decorrer do processo se resolução e questionar os motivos de se estar fazendo determinada operação ou mobilizando certo conhecimento utilizando-se de algum procedimento ou algoritmo específico em detrimento a outro, bem como a importância de se interpretar o que significa os números que foram encontrados, e principalmente o que se entende a partir daquele dado que foi apontado como resposta para o problema. Resoluções como essas, começam a enriquecer uma hipótese de que, não reconhecendo corretamente o que deve ser feito, alguns estudantes partem para realização de operações aleatórias, o que também é relatado, posteriormente nessa dissertação, por estudantes que registraram as atividades realizadas nos grupos em que estavam inseridos.

Entre os protocolos que não apresentaram uma solução correta, vale destacar algumas propostas de resolução por sua atipicidade.

O participante 27 relata ter resolvido a questão da seguinte forma: "transformei os 680 dias em porcentagem e multipliquei pelo valor das voltas que a estação deu em torno da terra" (E1227) realizando o seguinte cálculo $86.500^{*} 6,8 \%=5.882$ voltas, e ainda registrando que $5.460=54,6 \%$. Ele considera que para se "transformar um número em porcentagem" basta dividir o mesmo por 100, considerando 680 dias como $6,8 \%$ demonstrando dificuldades na aprendizagem do conceito de porcentagem.

Outra forma de resolução que pode ser destacada é o protocolo do participante 01 que utilizou a quantidade de dias do ano como se fosse a quantidade de voltas dadas em um ano, então, da quantidade total de voltas em 15 anos, 86.500, ele subtraiu 365 por ano até chegar em 1 ano e depois somou os 315 dias que estavam faltando para completar os 680 dias. $O$ estudante organizou uma tabela relacionando os anos e a quantidade de voltas para se certificar que estava realizando o procedimento correto. 


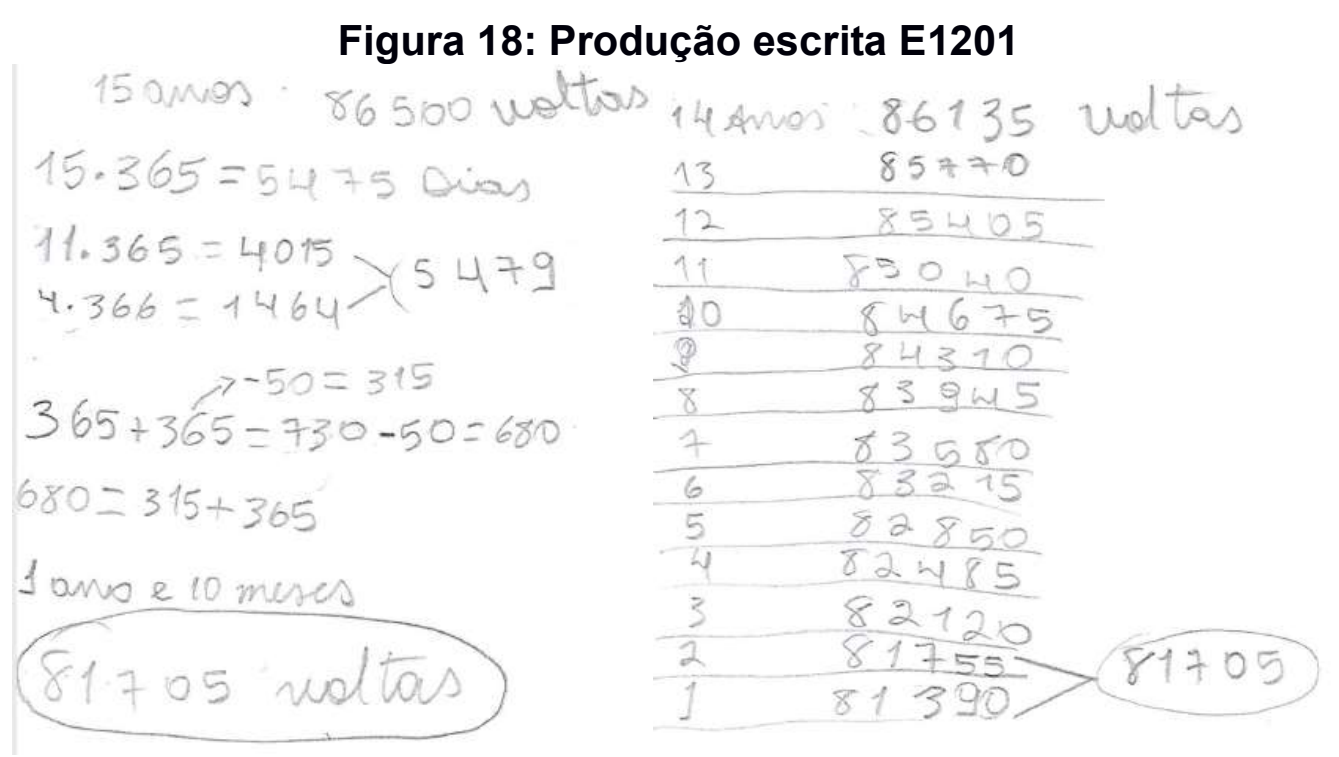

Fonte: Arquivo pessoal da pesquisadora

Esse estudante, que obteve o resultado de 81.705, registrou ter percebido que 680 dias era de aproximadamente 1 ano e 10 meses. Caso tivesse refletido acerca do resultado encontrado, poderia perceber que existe uma incoerência do número de voltas em 15 anos ser de 86.500 e em 1 ano e 10 meses ser de 81.705. Se em quase 2 anos a estação espacial tivesse dado 81.705 voltas, como afirmado na resposta, durante mais 13 anos ele deveria ter dado muito mais voltas. Nesse caso, se o professor pudesse fornecer um feedback para esse aluno, poderia auxilia-lo a refletir sobre sua resposta, estimulando-o a pensar criticamente sobre o item.

O aluno 16 realizou a seguinte conta: $680 * 24=16.320$, justificando sua resposta da seguinte forma: "peguei o número de dias e multipliquei pelo número de horas que um dia tem" (E1216). Esse procedimento sugere que o aluno não compreendeu o contexto do problema e nem o que era solicitado, utilizando as operações de forma aleatória, isto é, não existia uma estratégia estruturada que orientava o raciocínio desenvolvido na resolução do problema. Isso também foi observado em outros protocolos de resolução dos participantes e estes serão apresentados no decorrer da análise dos dados.

O estudante 04, por exemplo, não demonstrou ter uma estratégia para a resolução do problema, realizando diversas contas com os dados fornecidos, novamente nutrindo a hipótese de operações aleatórias, esboçando duas tentativas, infrutíferas de realizar uma regra de três. Vale destacar que uma delas estava correta, 
embora ele não tenha dado prosseguimento ao raciocínio, demonstrando-se um tanto confuso a partir da presença de contas diversas e falta de organização e clareza.

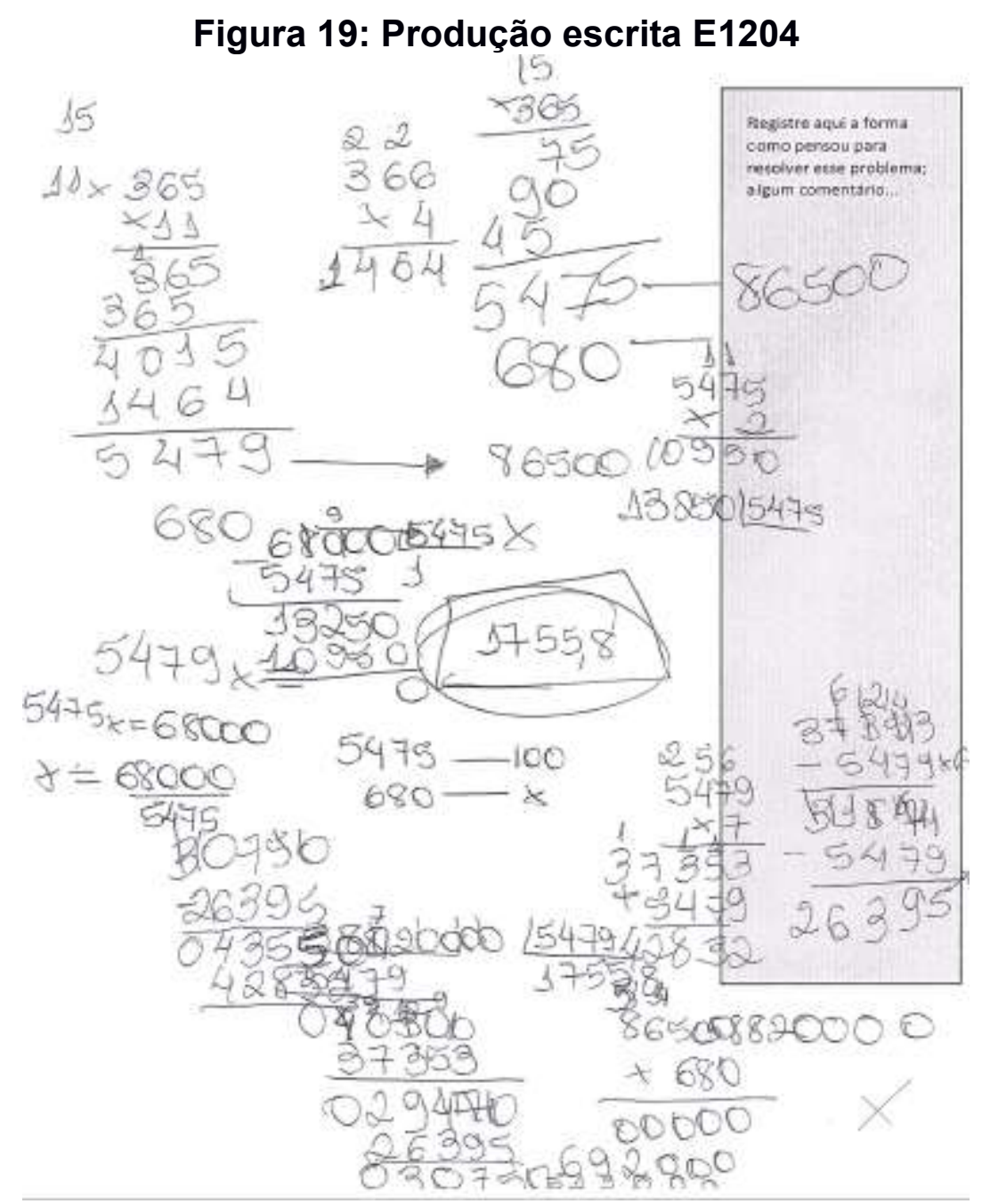

Fonte: Arquivo pessoal da pesquisadora

Durante o momento de feedback, pôde-se perceber que os alunos não demonstraram grande preocupação em elaborar ou formular uma estratégia estruturada para a resolução, como traçar um plano. Eles relataram que gastam pouco tempo interpretando o problema e refletindo sobre as possibilidades de percurso a serem adotados, partindo rapidamente para o processo de resolução (realizar as operações).

Esse dado é semelhante ao obtido por Schoenfeld (1992) quando realizou uma investigação desenvolvida por meio da aplicação de um problema não rotineiro, na qual alguns alunos, após lerem o enunciado, rapidamente selecionaram a estratégia 
que utilizariam para a resolução do mesmo. O autor relatou que, embora eles percebessem não alcançar soluções razoáveis na aplicação da estratégia adotada, optaram por insistir nesse caminho infrutífero até o final do tempo estipulado para a realização da tarefa, sem conseguir resolver o problema. Ao serem questionados em como a abordagem escolhida poderia ajudar na resolução, eles sequer conseguiram explicar. Cerca de $60 \%$ dos participantes em processo de resolução de problemas apresentaram procedimentos semelhantes: ler, decidir rapidamente como resolver e insistir na abordagem escolhida sem refletir sobre outras possibilidades; esse procedimento pode ser um fator a diminuir as chances de sucesso de resolução do problema por não flexibilizar as estruturas de pensamento ao longo do processo, revendo a estratégia utilizada.

O autor ainda destacou o processo de resolução de um problema por um expert. Assim, no desenrolar de um problema dito difícil é possível perceber que o sujeito dedica um tempo maior às etapas de análise, planejamento e implementação de um plano, verificando frequentemente se está no caminho certo, não focando apenas na execução/implementação, mas atuando de forma conjunta à análise e planejamento, monitorando os caminhos escolhidos e descartando os que parecem não tão promissores (avançando e retroagindo). Essa forma de resolução poderia ser associada ao retrospecto proposto por Polya (1994) onde o sujeito que está resolvendo o problema é levado a refletir constantemente sobre sua forma de resolução bem como sobre o resultado do problema.

Com relação as capacidades matemáticas fundamentais subjacentes aos processos matemáticos destacados pela OCDE, vale considerar o delineamento da estratégia para resolução de problemas.

o letramento matemático exige, em geral, o delineamento de estratégias para
a solução de problemas matemáticos. Isso envolve um conjunto de processos
críticos de controle que norteiam o indivíduo para que efetivamente
reconheça, formule e resolva problemas. Essa capacidade é caracterizada
pela seleção ou delineamento de um plano ou estratégia de usar a
matemática para resolver problemas decorrentes de uma tarefa ou contexto,
bem como para orientar sua execução, podendo ser exigida em qualquer das
etapas do processo de resolução de problemas. (BRASIL, 2016b,p. 143)

O delineamento de estratégias a ser utilizado para a resolução de um problema é uma das capacidades necessárias para o letramento matemático, que leva o sujeito a refletir sobre qual estratégia poderia utilizar para a resolução, se existem outras 
formas de se resolver esse problema, bem como qual seria a mais adequada, dentre outros questionamentos.

Figura 20: Produção escrita E1223.

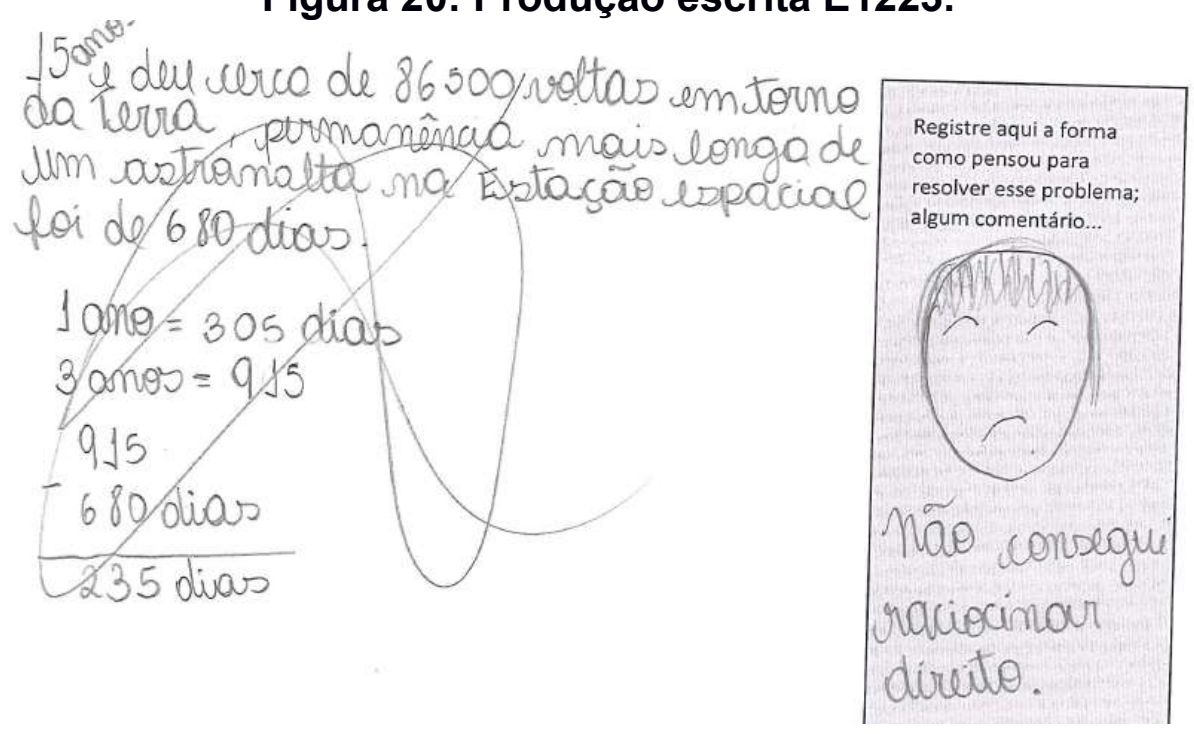

Fonte: Arquivo pessoal da pesquisadora

Nesse caso o participante desistiu de resolver o problema rabiscando por cima da resolução que havia iniciado, demonstrando que não estava correta. Vale destacar ainda que esse participante considerou que um ano correspondia a 305 dias, não podendo se concluir se foi um ato falho, decorrente de uma escrita apressada, sentindo-se pressionado no ambiente da sala de aula com uma pessoa estranha aplicando questões, ou se o mesmo não possui corretamente a informação acerca do número de dias em um ano.

Fávero (2009), em estudos cuja abordagem tangencia a temática de resolução de problemas em matemática, mostrou que o aluno, por vezes, buscava descobrir, quase por forma de adivinhação, qual era a fórmula ou o algoritmo correto a ser aplicado sem realmente distinguir o motivo de se usar uma determinada forma em lugar à outra, o que reforça a hipótese do que fora observado neste trabalho, qual seja das operações aleatórias. Isso pode estar relacionado a uma representação social da matemática que leva os indivíduos a considerar que essa área do conhecimento se caracteriza exclusivamente por fazer contas, manipulando números. Essa representação, infelizmente, atua de forma a dificultar uma compreensão adequada 
acerca do que caracteriza a atividade matemática e da sua utilidade para desenvolver diversas capacidades humanas.

Situação semelhante a destacada pela autora pode ser percebida em alguns protocolos da presente pesquisa, como por exemplo no protocolo de resolução do participante 40 onde é possível inferir que o mesmo não tinha um plano para a resolução do problema proposto, realizando várias operações de forma quase aleatória, na tentativa de encontrar alguma resposta.

\section{Figura 21: Produção escrita E1240}

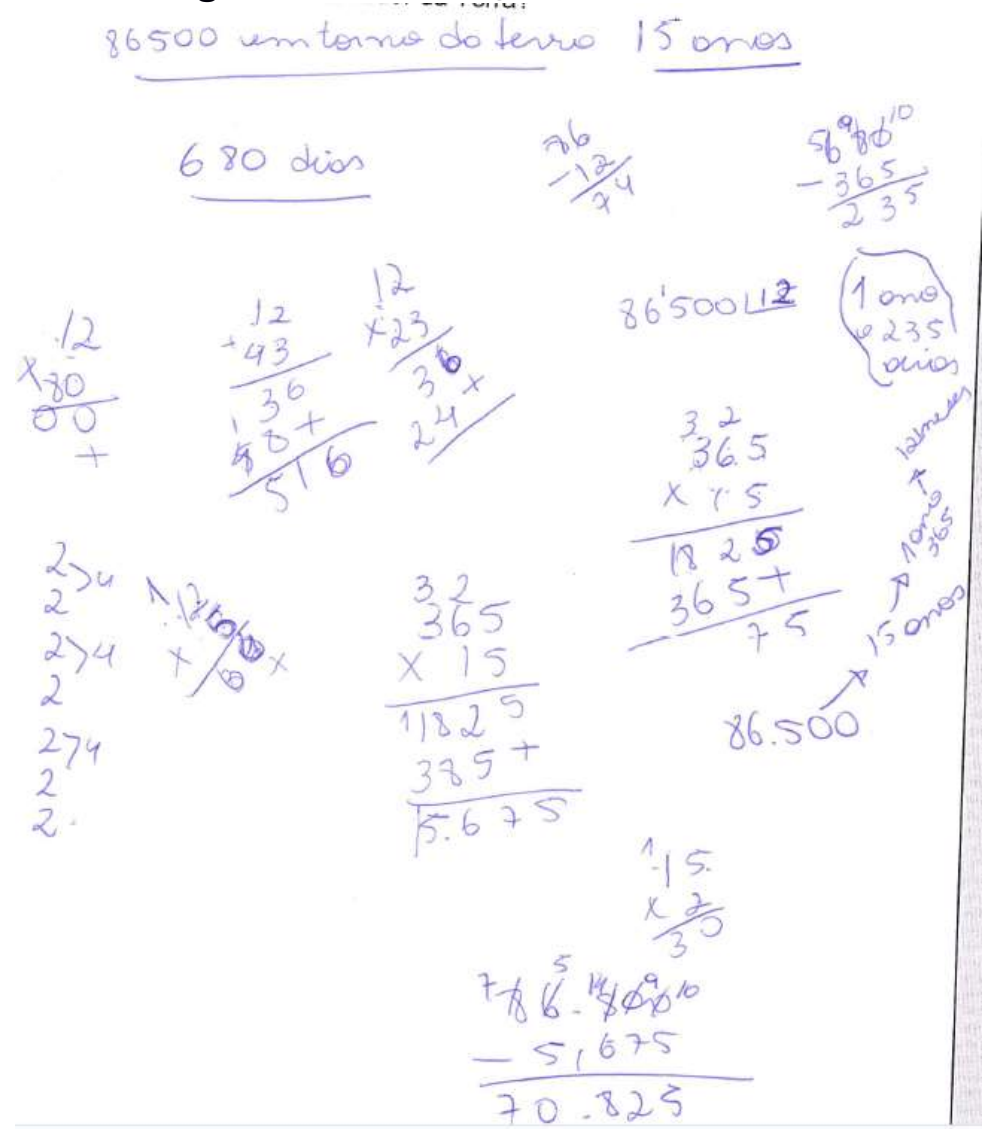

Fonte: Arquivo pessoal da pesquisadora

Pode-se perceber ainda que o aluno teve certa dificuldade em realizar algumas operações fundamentais da aritmética, errando e/ou deixando em branco a resolução de algumas operações de subtração, multiplicação e divisão. Vale ressaltar que eles podem utilizar a calculadora no dia-a-dia em sala de aula e também foi autorizado que eles utilizassem durante a atividade. No entanto, embora tenha sido previamente acordado com os estudantes acerca de levarem calculadora à sala de aula, nem todos 
cumpriram com o combinado, tendo esses que realizar as tarefas sem esse recurso. Outros erros relacionados as 4 operações fundamentais da aritmética puderam ser percebidos na resolução de outros participantes:

Tabela 6: Erros relacionados as 4 operações fundamentais da aritmética

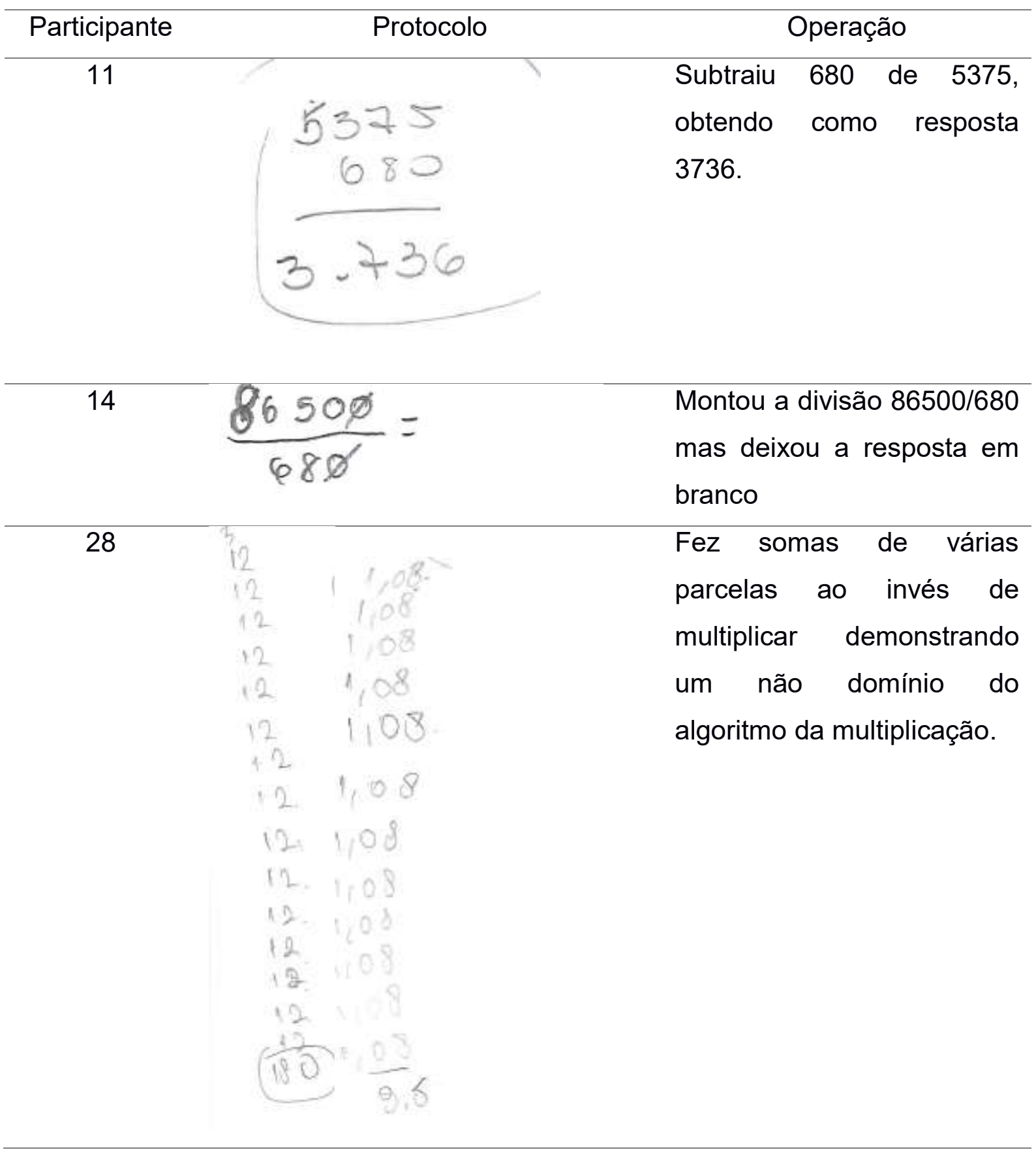




\section{7}

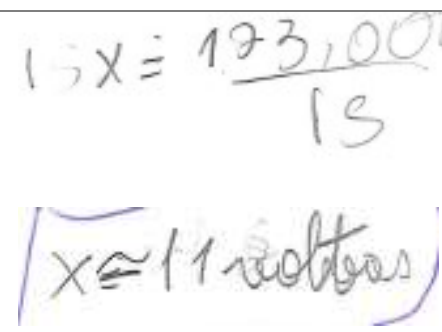

Ao dividir 173.000 por 150 aluno dividiu 17 por $15 \mathrm{e}$ "esqueceu de colocar" os outros três zeros.

Fonte: Elaborado pela pesquisadora

Essas resoluções põem em destaque as dificuldades que os estudantes apresentam na resolução das 4 operações básicas em um momento muito próximo da conclusão do Ensino Médio. Além de alguns equívocos na execução das operações foi possível perceber que alguns gastavam muito tempo para resolver as contas, sendo que nessa etapa de escolarização era esperado que eles já tivessem um domínio maior, e até certa automatização, na resolução dessas 4 operações. Esse pode ser um dos fatores a influenciar o desenvolvimento dos alunos em atividades relacionadas à matemática.

\subsubsection{Segunda Atividade Individual}

O problema rotineiro da segunda atividade foi extraído do Exame Nacional do Ensino Médio aplicado em 2015, e contou com a seguinte redação: 
Alguns exames médicos requerem uma ingestão de água maior do que a habitual. Por recomendação médica, antes do horário do exame, uma paciente deveria ingerir 1 copo de água de 150 mililitros a cada meia hora, durante as 10 horas que antecederiam um exame. A paciente foi a um supermercado comprar água e verificou que havia garrafas dos seguintes tipos:

- Garrafa I: 0,15 litro

- Garrafa II: 0,30 litro

- Garrafa III: 0,75 litro

- Garrafa IV: 1,50 litro

- Garrafa V: 3,00 litros

A paciente decidiu comprar duas garrafas do mesmo tipo, procurando atender à recomendação médica $\mathrm{e}$, ainda, de modo a consumir todo o líquido das duas garrafas antes do exame. Qual o tipo de garrafa escolhida pela paciente?

Nove alunos apresentaram respostas corretas, sendo possível propor duas categorias distintas acerca das estratégias de resolução adotadas. Na primeira categoria, 7 alunos consideraram a quantidade de água do copo multiplicando-a pelo quantitativo de copos que deveria ser ingerido em 10 horas; enquanto na segunda categoria os alunos consideraram a quantidade de água que deveria ser ingerida em 1 hora, multiplicando pela quantidade de horas, a partir do seguinte cálculo 300*10/2 (17 e 29).

A primeira categoria foi subdivida em outras duas, nas quais os processos de resolução são semelhantes, só divergindo o momento em que os alunos fizeram a conversão das unidades de medida. No primeiro subgrupo eles optaram por converter o valor de mililitro para litro no final da questão, realizando, portanto, $150 * 20 / 2=1.500$, o que equivale a $1,5 \mathrm{l}$; já no segundo, fizeram a conversão de $150 \mathrm{ml}$ para $0,15 \mathrm{I}$, realizando a conta $0,15^{*} 20 / 2$. 
Figura 22: Produção escrita E2237.
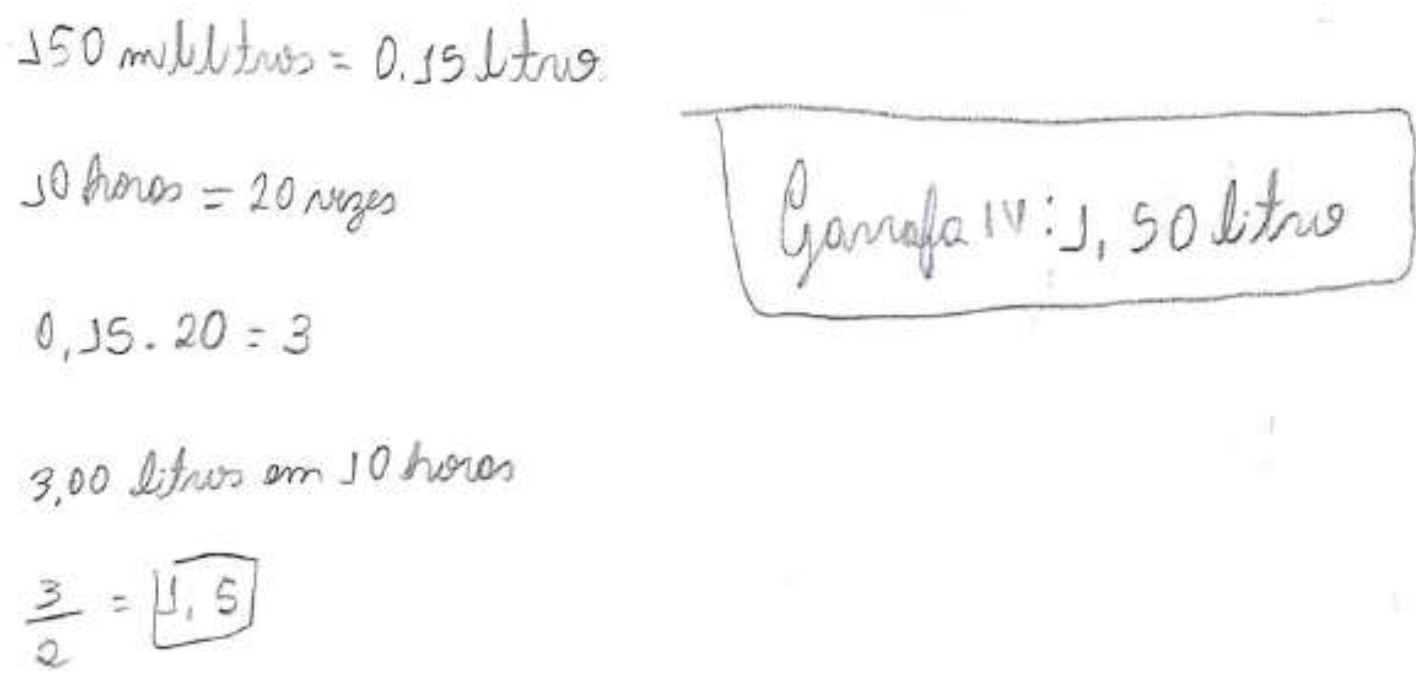

Fonte: Arquivo pessoal da pesquisadora

Na segunda categoria, encontraram primeiramente o valor a ser ingerido por hora e posteriormente a ingestão total em 10 horas. Dois alunos utilizaram esse raciocínio, sendo destacado que a resposta seria a "garrafa de número IV já que ela deveria tomar $150 \mathrm{ml}$ a cada 30 minutos, $300 \mathrm{ml}$ a cada $1 \mathrm{hr}$, então em $10 \mathrm{hrs}$ tomaria $3000 \mathrm{ml}$ ou 3 l" (E2229) dividindo posteriormente esse valor por 2 para determinar o tipo da garrafa. O participante 17 detalhou o consumo em cada hora para facilitar seu entendimento de quanto seria consumido em 10 horas. 
Figura 23: Produção escrita E2217.

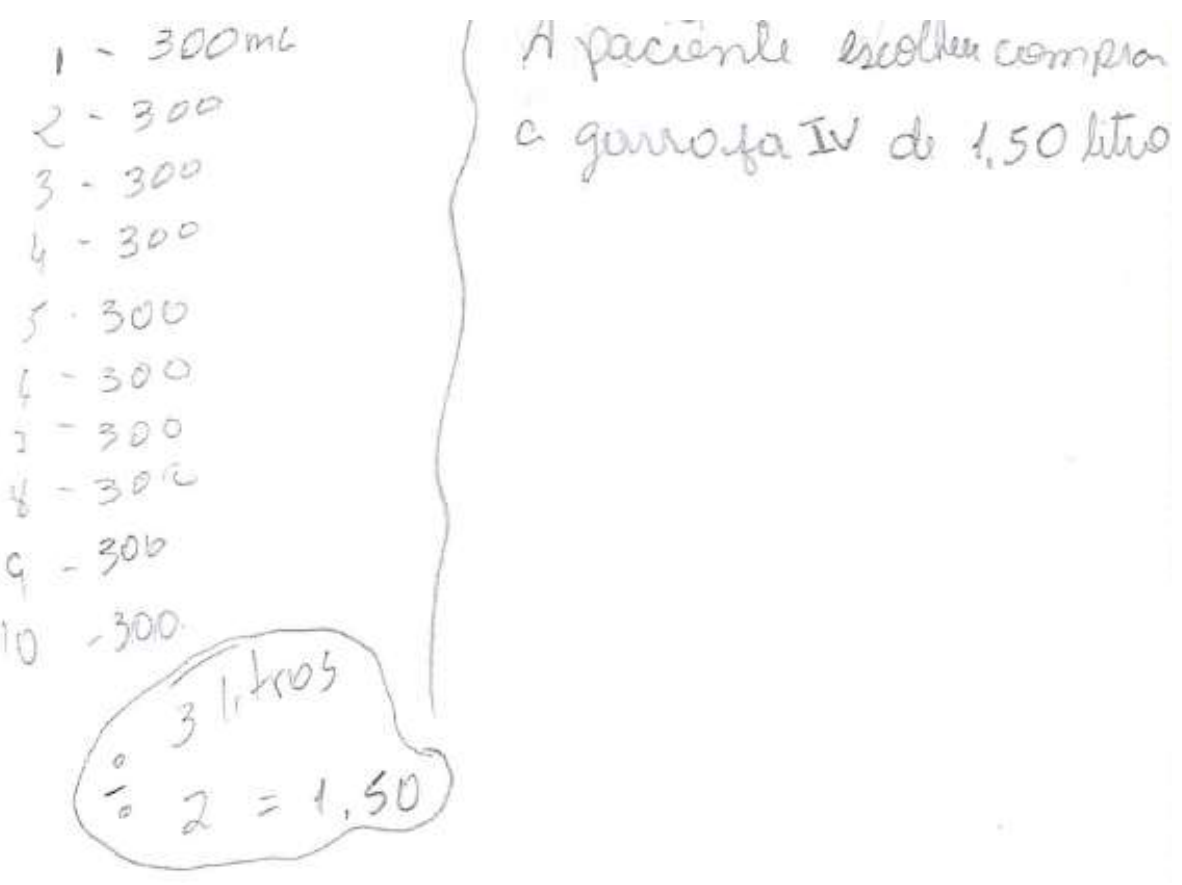

Fonte: Arquivo pessoal da pesquisadora

Dois alunos que acertaram fizeram uma representação/tabela das 10 horas para auxiliar a descobrir quantos copos eram necessários nesse período. Essa estratégia foi sugerida no momento de feedback para que os alunos pudessem esboçar algum tipo de ilustração (desenho, tabela...) para facilitar no entendimento do contexto.

Vale destacar que nenhum aluno que acertou essa questão utilizou regra de 3 para resolver o problema optando por utilizar multiplicações e divisões dos dados fornecidos. Os 4 alunos que tiveram um acerto parcial demonstraram ter compreendido parcialmente o contexto da questão, mas incorreram em algum equívoco no decorrer da resolução. Os alunos 2,13 , 39 resolveram da mesma forma que a primeira categoria de alunos que acertaram realizando $150^{\star} 20$, mas o aluno 2 não acertou apenas em uma divisão final ao colocar $3,00 / 2=0,15$, enquanto os alunos 13 e 39 chegaram ao resultado de 3 litros, embora tenham esses esquecidos de considerar que o paciente decidiu comprar duas garrafas e, portanto, dividir esse resultado por 2 . 
Figura 24: Produção escrita E2202.

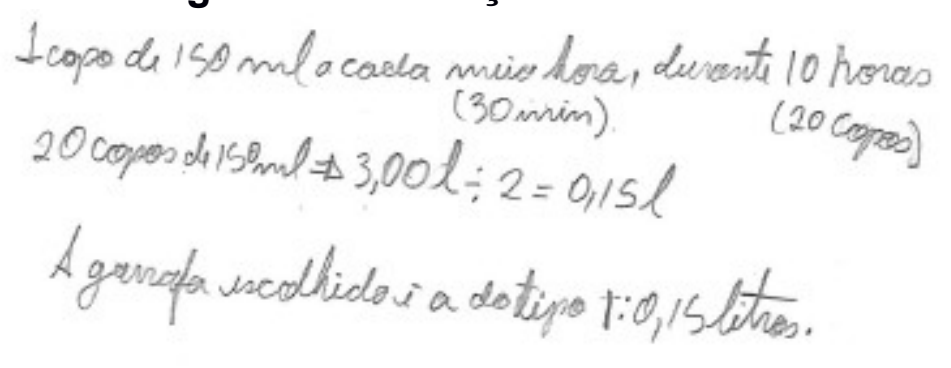

Fonte: Arquivo pessoal da pesquisadora

Dos 16 alunos que erraram essa questão, pôde-se perceber que alguns começaram a resolver o problema, mas não conseguiram perceber todas as variáreis envolvidas, faltando realizar ainda algum procedimento para obter o resultado final. Pode ser citado alguns exemplos com relação a essas produções: 150*10/2 (24 e 25) e $150 * 2 * 10$ (11).

$\mathrm{O}$ aluno 41 montou uma regra de 3 relacionando corretamente as grandezas considerando que se ocorre a ingestão de $150 \mathrm{ml}$ em 0,5 h então haverá a ingestão de $\mathrm{x} \mathrm{ml} \mathrm{em} 10$ horas, tendo um raciocínio semelhante aos dos alunos da primeira categoria que acertaram. Esse aluno efetuou uma multiplicação cruzada, acertando o algoritmo da regra de 3, mas não acertou na divisão final. É possível associar que ele realizou incorretamente a operação a partir de falas recorrentes de alguns docentes acerca de quando estão a lecionar simplificação de frações: "quando tem zero em cima e embaixo pode cortar". Cabe destacar que essa é uma forma reducionista de se considerar a simplificação de frações na qual o aluno, de forma mecanizada, "corta" zeros ainda que talvez desconheça a razão disso. Além disso, ele também não obteve o resultado correto na divisão dos números restantes e no posicionamento da vírgula ao considerar que $150 / 5=3,00$. Possivelmente ele considerou o valor 3 para a divisão 150/5 pelo fato desse número estar como uma das alternativas dadas no problema. 
Figura 25: Produção escrita E2241.

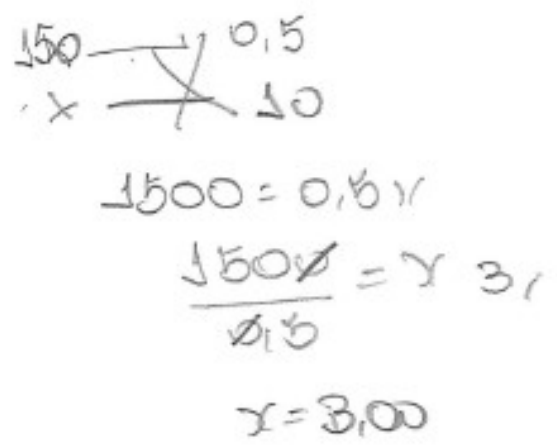

Fonte: Arquivo pessoal da pesquisadora

Outros dois alunos que erraram não conseguiram demonstrar que entenderam o contexto da questão, utilizando os dados do problema como se não soubessem de fato o que tinham que fazer ou como proceder. Outra hipótese é de que ele pode não ter conseguido registrar por escrito seu raciocínio para resolver o problema. Pode-se tomar como exemplo algumas produções: 150/2 (35 e 40) 150+10*(1,5) (21).

Figura 26: Produção escrita E2228.

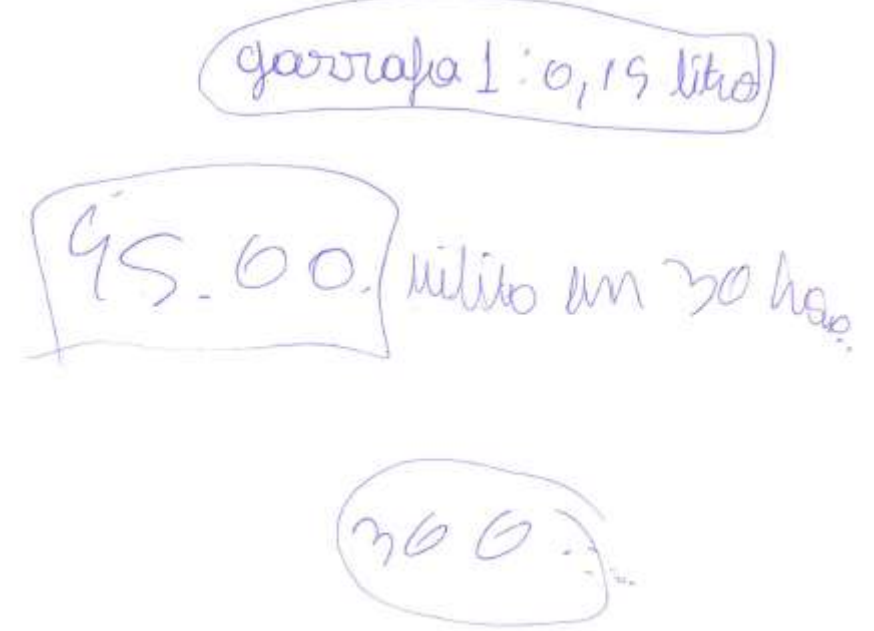

Fonte: Arquivo pessoal da pesquisadora 
Figura 27: Produção escrita E2238.

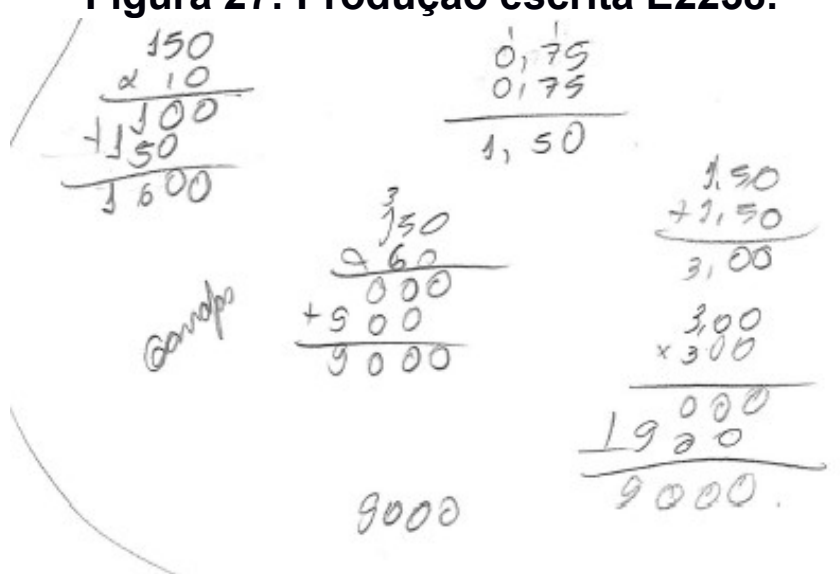

Fonte: Arquivo pessoal da pesquisadora

Esse fato dos alunos realizarem cálculos aleatórios e sem uma estratégia para a resolução já foi destacada na primeira atividade desenvolvida. Nenhum dos alunos que erraram a questão percebeu que o paciente deveria beber 20 copos d'água, ou que nessas 10 horas beberia 3 litros pois ele deveria ingerir 1 copo de água de 150 mililitros a cada meia hora, durante as 10 horas.

Cinco participantes acertaram o resultado, embora as operações apresentadas não justificassem a resposta, ou seja, não deixando claro como resolveram a questão, uma vez que realizaram cálculos que não justificaram a resposta - chegaram a resposta correta, apesar de o raciocínio de resolução da questão não ser adequado. As produções desses participantes foram consideradas incorretas. Talvez isso tenha ocorrido devido as possíveis alternativas que eram propostas no enunciado da questão, talvez se não tivesse esses dados no enunciado os alunos não teriam proposto essa resposta.

Figura 28: Produção escrita E2232.

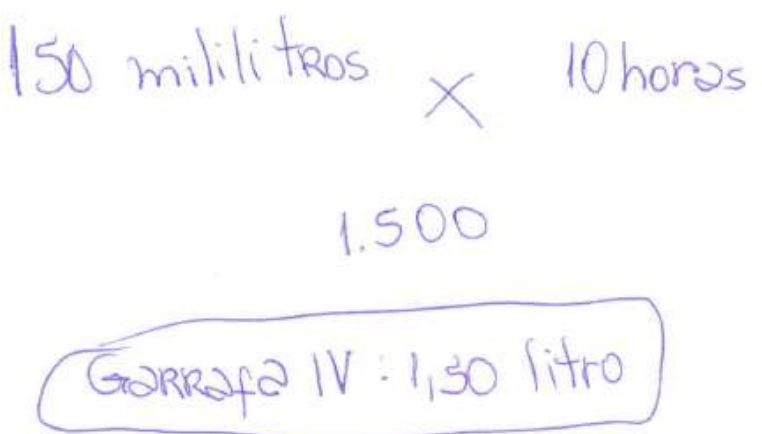

Fonte: Arquivo pessoal da pesquisadora 
O aluno 14 indicou que a resposta seria "a garrafa IV de 1,50 litros, pois movendo-se a vírgula transforma-se em mililitros", além de não ter compreendido o contexto do problema, ao se realizar a transformação das unidades de medidas dessa forma, demonstrou uma fragilidade nesse conceito. Isso pode ser reflexo de um aprendizado mecanizado da conversão das unidades de medida, pois o aluno demonstrou saber que deveria mover a vírgula, mas para se transformar $\mathrm{ml} \mathrm{em} \mathrm{I} \mathrm{deve-}$ se "voltar 3 casas" e não duas como fez o aluno. Além disso, para se resolver essa questão não bastava apenas transformar $150 \mathrm{ml}$ em litros.

O aluno 34 afirmou que 1 litro equivale a 500 mililitros.

Figura 29: Produção escrita E2234.

Fonte: Arquivo pessoal da pesquisadora

A falta de conhecimentos básicos relacionados a dados referentes a realidade já foi destacado na primeira questão individual quando um aluno afirmou que um ano tinha 305 dias (Figura 20), o que provoca reflexões acerca de qual o propósito da matemática: ensinar álgebra e geometria para se efetuar cálculos essencialmente padronizados ou estimular uma habilidade de leitura do mundo, conhecendo valores e variáveis presentes no cotidiano, que permite matematizar situações presentes na vida de um cidadão? Um questionamento que serve como reflexão para outros estudos. 


\subsubsection{Atividade em Grupo}

O problema rotineiro selecionado para a atividade em grupo foi da prova da OBMEP do ano de 2015:

Para assar um frango são necessários 15 minutos para aquecer o forno e mais 12 minutos para assar cada meio quilo de frango. Paula comprou um frango de $2,5 \mathrm{~kg}$. A que horas ele deve ligar o forno para que o frango fique pronto às 20 horas?

A coleta de informações revela que 1 grupo não acertou a forma de resolução, enquanto 7 acertaram. Desses, todos fizeram da mesma forma, conforme descrito pelo grupo D: "multiplicamos $12 * 5$ que deu 60 minutos. Depois somamos os 15 minutos para o forno esquentar e diminuímos pela as 20h" (G2D) chegando a resposta de 18 horas e 45 minutos. A questão propõe que são necessários 12 minutos para assar cada meio quilo de frango, para descobrir quantos meios quilos tinham em 2,5 $\mathrm{kg} 2$ grupos (A e F) anotaram as parcelas de 0,5 kg necessárias e relacionou-as com os 12 minutos para chegar ao tempo de 60 minutos.

Figura 30: Produção escrita G1A.

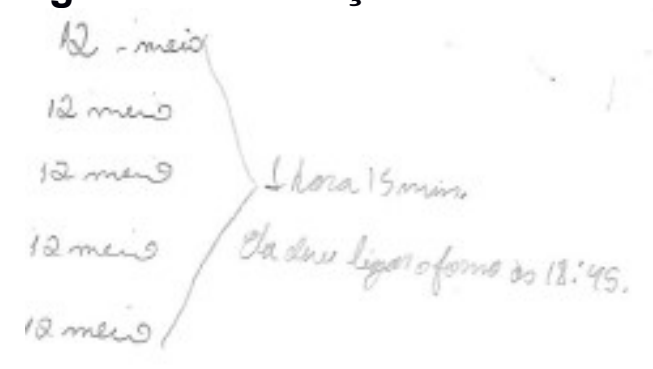

Fonte: Arquivo pessoal da pesquisadora 
Figura 31: Produção escrita G1F.

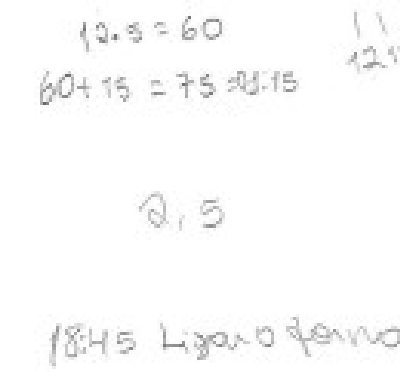

Fonte: Arquivo pessoal da pesquisadora

Os demais grupos não registraram como descobriram o valor 60 , provavelmente tenham realizado essa contagem mentalmente, sem necessidade do papel, ou registraram os cálculos em outro lugar. Vale destacar ainda que todos os grupos perceberam que 75 minutos corresponde a 1 hora e 15 minutos. Apenas um grupo não obteve êxito na resolução da questão considerando que o tempo era equivalente a 135 minutos, sem embasar a forma de resolução.

Figura 32: Produção escrita G1C.

Fonte: Arquivo pessoal da pesquisadora

Observe-se que nenhum dos grupos utilizou a regra de 3 para a resolução do problema, realizando divisões e multiplicações.

\subsection{Problema Não-rotineiro}

\subsubsection{Primeira Atividade Individual}

O problema não-rotineiro trabalhado na primeira atividade individual foi o seguinte item do Enem (2015): 
A insulina é utilizada no tratamento de pacientes com diabetes para o controle glicêmico. Para facilitar sua aplicação, foi desenvolvida uma "caneta" na qual pode ser inserido um refil contendo $3 \mathrm{ml}$ de insulina, como mostra a imagem.

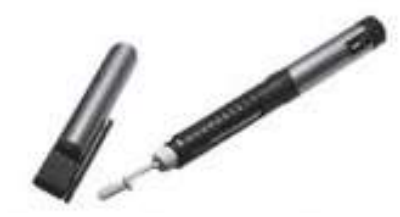

Para controle das aplicações, definiu-se a unidade de insulina como 0,01 $\mathrm{ml}$. Antes de cada aplicação, é necessário descartar 2 unidades de insulina, de forma a retirar possíveis bolhas de ar. A um paciente foram prescritas duas aplicações diárias: 10 unidades de insulina pela manhã e 10 à noite. Qual o número máximo de aplicações por refil que o paciente poderá utilizar com a dosagem prescrita?

Esse problema foi o que teve o menor índice de acerto das questões aplicadas nesse dia. Dos 36 alunos que participaram dessa atividade, apenas 2 acertaram a questão, 3 apresentaram solução parcialmente correta, 23 não apresentaram uma solução razoável e 8 não responderam o problema. Quanto aos estudantes que alcançaram êxito no problema em referência, destaca-se que ambos fizeram de forma semelhante, percebendo que nesse problema deveria ser considerado o descarte de 2 unidades de insulina somando-as às unidades que deveriam ser aplicadas. Posteriormente, dividiram a quantidade de insulina que tinha no refil por esse valor inicialmente encontrado: $3 / 0,12=25$. Vale destacar que nenhum dos dois resolveram a questão utilizando a regra de 3 . Um desses alunos descreveu sua resolução: "dividi a quantidade de $\mathrm{ml}$ por refil pela quantidade de ml por aplicação" (E1308). 
Figura 33: Produção escrita E1308

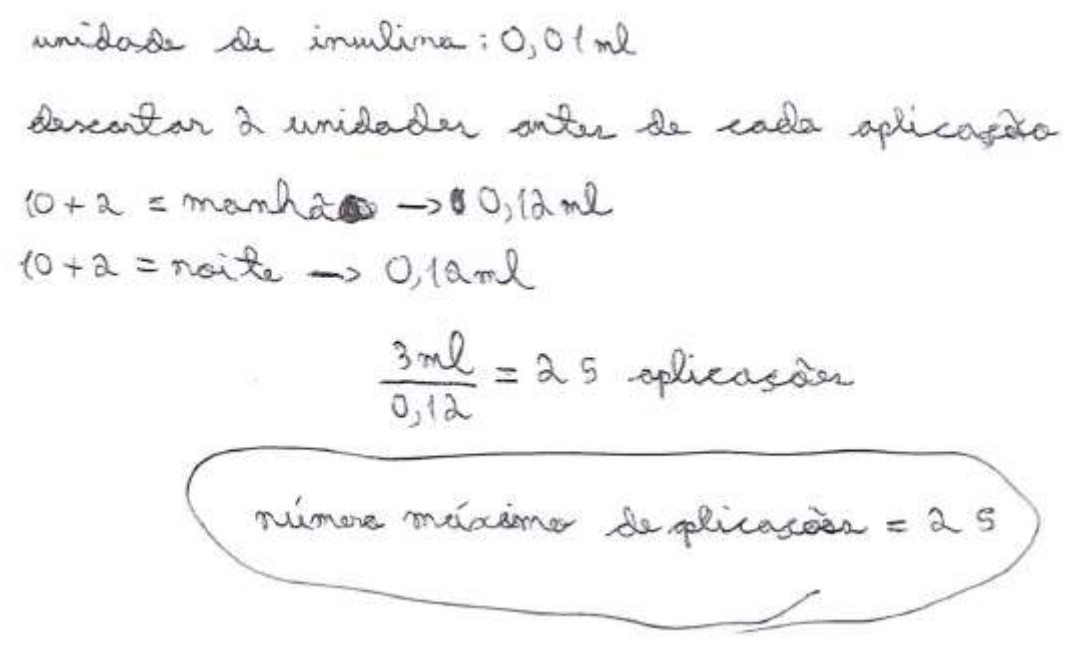

Fonte: Arquivo pessoal da pesquisadora

Os 3 participantes que apresentaram uma resposta parcialmente correta demonstraram ter compreendido corretamente o contexto da questão, muito embora não tenham considerado o descarte das 2 unidades de insulina da aplicação, obtendo por fim o resultado de 30 aplicações.

Figura 34: Produção escrita E1334

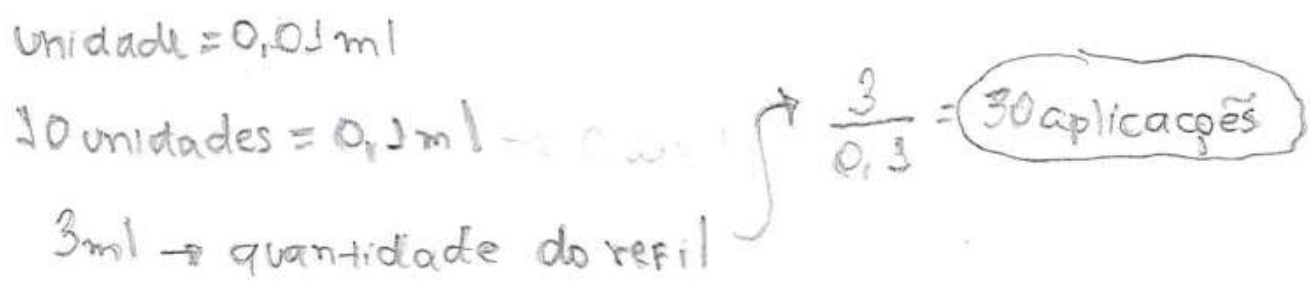

Fonte: Arquivo pessoal da pesquisadora

O participante 02 demonstrou ter compreendido parcialmente o contexto da questão, bem como o que estava sendo solicitado, todavia ele cometeu equívocos na interpretação do problema: subtrair 2 unidades da dosagem obtendo uma dosagem de 8 unidades; e, considerar como se uma aplicação fosse a soma das duas aplicações, obtendo o valor de 0,16 ml por aplicação. 


\section{Figura 35: Produção escrita E1302}

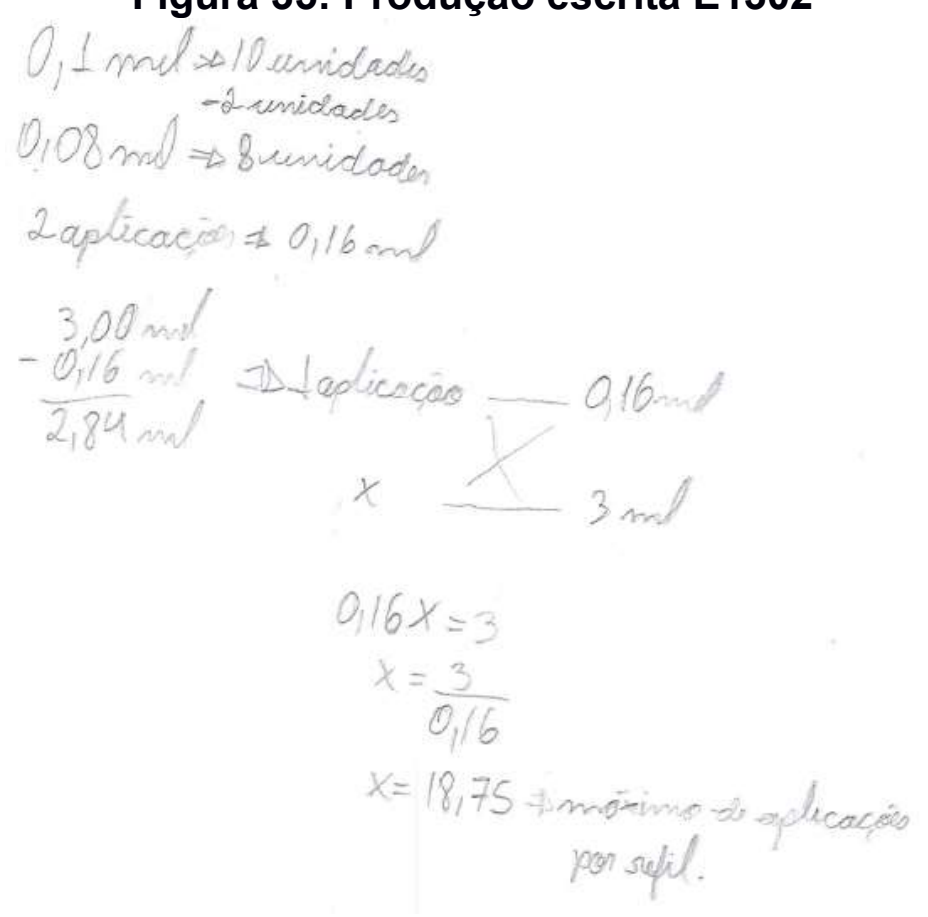

Fonte: Arquivo pessoal da pesquisadora

Se o estudante tivesse calculado corretamente o quantitativo de $\mathrm{ml}$ por aplicação, teria encontrado a solução do problema, pois conseguiu relacionar as grandezas e realizar a regra de três. Apesar de ele ter cometido dois equívocos com relação a interpretação do problema, de uma forma geral, demonstrou ter compreendido a proposta do problema.

Outros 2 participantes tentaram resolver a questão utilizando regra de 3 , mas nenhum deles obtive a resposta correta pois associaram as grandezas de uma forma inadequada, conforme a figura a seguir:

Figura 36: Produção escrita E1309

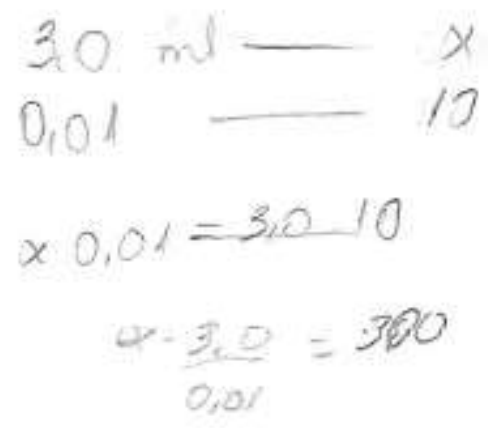

Fonte: Arquivo pessoal da pesquisadora 
Os três conseguiram resolver corretamente a regra de 3 que montaram, evidenciando que dominam esse procedimento de cálculo, entretanto, não obtiveram a solução correta em função de dificuldades para interpretar a questão e associar as grandezas corretamente, ou por erro em alguma das 4 operações aritméticas.

Dalto e Buriasco (2009, p.452) destacam que

quando o professor corrige a produção escrita de um estudante e considera apenas
a resposta da questão como totalmente certa ou errada, estará perdendo uma
oportunidade de verificar os conhecimentos que ele já elaborou e aqueles que estão
em processo de elaboração, assim como os erros cometidos pelos estudantes, que
podem fornecer importantes informações sobre o processo de ensino e de
aprendizagem.

Partindo do entendimento de que a análise do erro como uma estratégia é algo salutar na busca do aprendizado, Muniz (2009, p. 123) pontua que "o erro na produção não está na ausência do conhecimento, mas na mobilização de esquemas numa situação na qual ela é inapropriada", colocando que tendo o aluno produzido respostas destoantes das corretas, não significa que ele não tenha qualquer conhecimento sobre o assunto, mas que pode estar em fase de significação e construção do conceito correto, carecendo, portanto, de uma intervenção apropriada.

Dessa forma, espera-se que o equívoco cometido pelo estudante não seja tratado como uma forma de punição para o estudante, mas como uma oportunidade para explorar a sua produção, analisando onde e porque não conseguiu obter o resultado esperado, de forma individual ou com outro aluno, ou ainda com auxílio do professor. Essa oportunidade caracteriza-se como um momento da avaliação formativa, isto é, avaliar para orientar as aprendizagens, sinalizando os potenciais evidenciados na produção do estudante bem como indicando os pontos que requerem atenção e desenvolvimento.

Dos 23 que não apresentaram uma solução correta, foram identificadas 20 repostas diferentes, sendo que 2 responderam 8 (10-2); 2 responderam 16 [(10-2)*2]; e 2 responderam $60\left(3^{*} 10^{*} 2\right)$. Com essa informação pode-se perceber a diversidade de respostas e resoluções fornecidas ao problema em questão. Apesar do problema apresentado ser o mesmo, com as mesmas informações, os alunos interpretaram e resolveram de formas bem diferente uns dos outros. Com relação ao valor das respostas, as mesmas variavam de 0,05 a 1000, demonstrando um grande intervalo de variação das respostas. Esses dados são semelhantes aos encontrados em problemas rotineiros. 
Pode ser percebido que a informação de que seria necessário descartar 2 unidades de insulina levou grande parte dos alunos a um equívoco. Dos participantes que erraram essa questão, 12 não consideraram a informação que deveria ser descartado 2 unidades, enquanto 10 subtraíram 2 unidades de algum valor e apenas um somou esse valor às 10 unidades. Ou seja, aproximadamente $43,5 \%$ dos participantes que erraram essa questão consideraram descartar 2 unidades, subtraindo esse valor das unidades de insulina a serem aplicadas, sendo que o correto seria se incluir o valor dessas duas unidades que deveriam ser descartadas junto à dose do paciente, para que, após o descarte dessas 2 unidades ficasse na seringa as 10 unidades prescritas. Nesse caso em específico, para se descartar essas 2 unidades eles teriam que somar esse valor às 10 unidades que esse paciente deveria tomar.

Tal equívoco recorrente junto a esses alunos pode estar ligado a palavra descartar e a uma visão reducionista da mesma, sendo que essa palavra, geralmente, é associada a uma subtração. Essa abordagem reducionista pode estar associada a alguns conceitos, como por exemplo quando em uma questão se tem palavras do tipo diminuir, retirar, descartar, elas por vezes dão a ideia de se "tirar", sendo assim, o aluno geralmente é induzido a perceber que a operação a ser utilizada corresponde a uma subtração, desconsiderando o contexto mais amplo em que a palavra está inserida. Nesse caso os estudantes possivelmente consideraram essa associação sem analisar corretamente o contexto proposto na questão.

Dos que não acertaram a questão, apenas um aluno somou o valor a ser descartado às 10 unidades, dentre outros obstáculos para a resolução, o mesmo não acertou a questão por considerar 20 unidades a serem descartadas e não 2 como proposto no enunciado. Não houve nenhum cálculo para se fazer essa conversão, provavelmente, esse valor foi utilizado por um equívoco de leitura. 
Figura 37: Produção escrita E1333

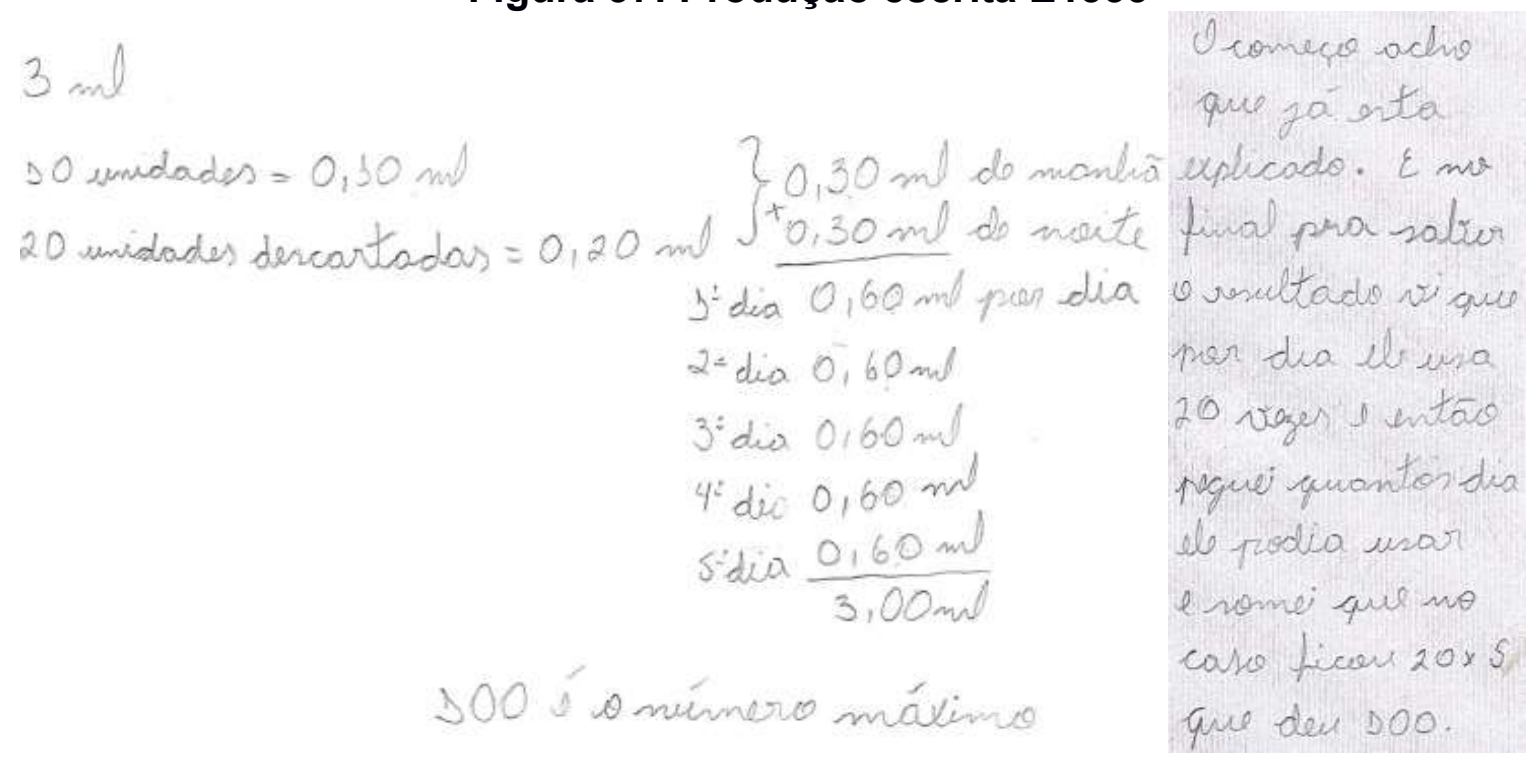

Fonte: Arquivo pessoal da pesquisadora

No encontro no qual foi realizado o feedback das produções da primeira atividade individual, foram apresentadas as formas de resolução mais comuns elaboradas pelos estudantes participantes da pesquisa em relação a essa questão, bem como os equívocos mais recorrentes.

Sendo assim, foi destacado o fato de retirar 2 unidades de insulina das 10 unidades que o paciente precisaria. Se assim fosse, o paciente receberia apenas 8 unidades de insulina, uma dosagem menor do que o volume prescrito pelo médico. Caso os alunos refletissem acerca da resposta apresentada, perceberiam que isso não poderia ser feito, pois ao tomar 8 unidades de insulina o paciente não estaria cumprindo com a prescrição médica.

Apesar de nenhum aluno ter recorrido a esta estratégia para auxiliar na resolução, foi realizado pela pesquisadora um desenho ilustrando a seringa e a situação proposta pelo problema para instigar os alunos a refletirem sobre quantas unidades de insulina deveriam ter na seringa, levando em consideração que seria necessário descartar duas unidades antes da aplicação para retirar possíveis bolhas de ar.

Desenhou-se uma seringa e a quantidade de 10 unidades que o paciente teria que receber, questionando junto aos alunos o que deveria ser feito para que fosse descartado 2 unidades de insulina e a seringa continuasse com as 10 unidades que $o$ paciente deveria tomar segundo a dosagem prescrita. Com isso, os alunos concluíram 
que para que fosse descartado 2 unidades de insulina teria que ser colocado mais 2 unidades dentro da seringa para manter a quantidade que o paciente teria que receber após o descarte. Ao se fazer o desenho, os alunos puderam perceber melhor que cada dose teria 12 unidades de insulina, sendo assim, foi destacado como uma ilustração e demais esquemas gráficos podem auxiliar para uma melhor interpretação do problema, deixando-o mais claro, facilitando a resolução do mesmo.

Vale ainda destacar a resolução de outro aluno, que relacionou essa questão a uma progressão aritmética utilizando a fórmula do termo geral da PA. O resultado obtido não solucionava o problema e revelou indícios de que o estudante não compreendeu adequadamente o conceito de PA. Esse participante ainda demonstrou certa insegurança com a resolução que propôs ao ressaltar que seu resultado provavelmente estaria errado. Vale destacar que a turma não estava estudando sobre PA no período da pesquisa.

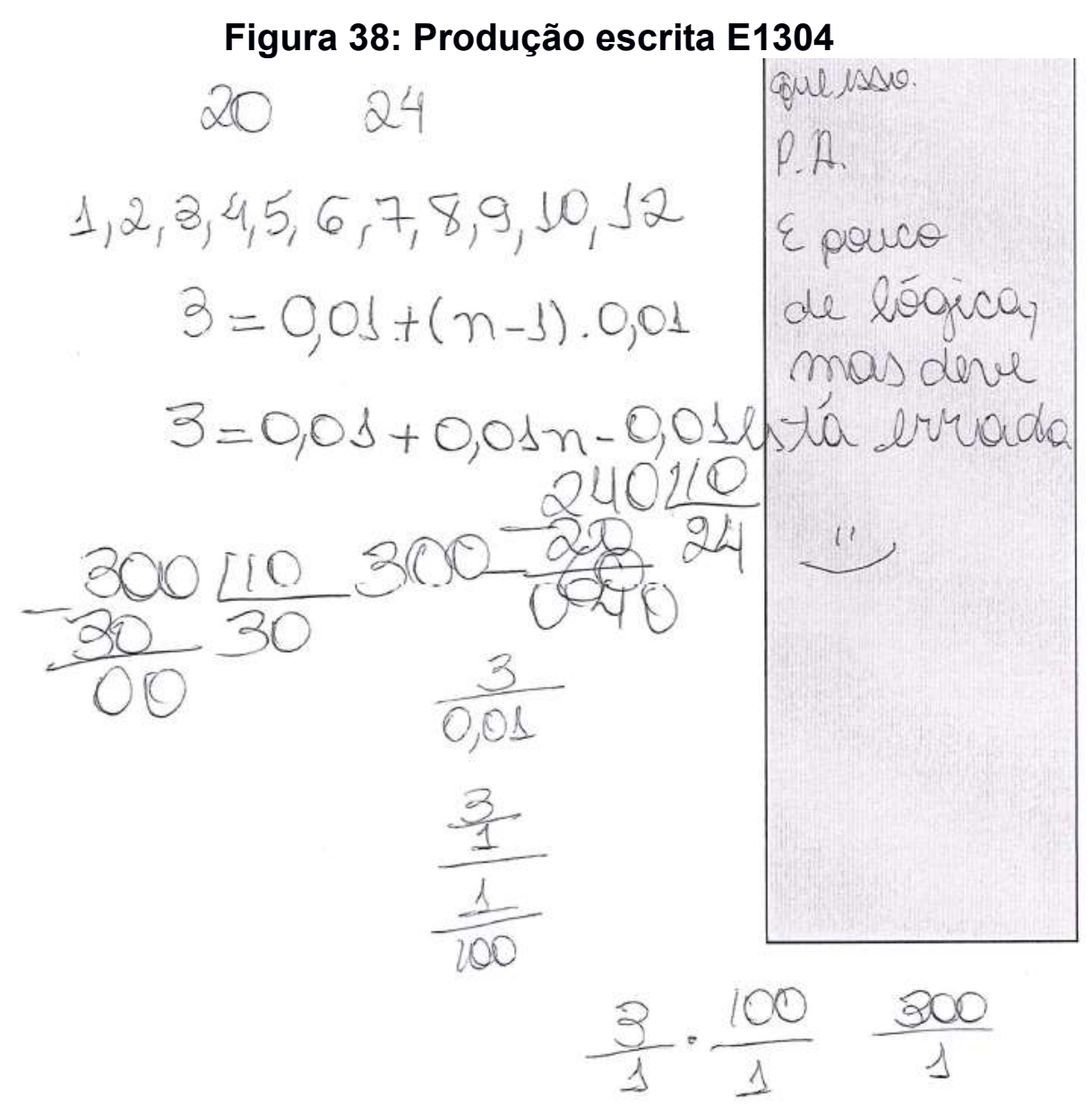

Fonte: Arquivo pessoal da pesquisadora 
Considere-se que a informação de que o paciente deve tomar duas aplicações diárias é irrelevante para a resolução do problema, mas muitos alunos utilizaram essa informação para resolvê-lo. Dos 23 que não obtiveram a resposta correta nessa questão, 16 utilizaram essa informação de alguma forma, tendo dobrado a dosagem a ser utilizada $(30+30=60)$ ou dividindo a dosagem em duas partes (alunos 21, 38 e 40), sendo que "então fica 5 unidades pela manhã e 5 unidades pela tarde" (E1338).

O enunciado já afirmava que foram prescritas 10 unidades de insulina para o paciente em cada um desses períodos, por ser um medicamento e a recomendação médica afirmar que seriam necessários para aquele paciente 10 unidades em cada período, esse valor não poderia ser dividido ou dobrado, pois poderia causar algum prejuízo à saúde do mesmo, esse dado pode ser outro fator que enfatiza que esses alunos não compreenderam o contexto da questão e o que estava sendo solicitado.

Além dessa dificuldade de interpretação, conforme destacado nas resoluções de problemas rotineiros, os alunos demonstraram não ter estabelecido um plano para resolver o problema. Um exemplo foi registrado por um aluno, que disse: "usei a divisão para obter o resultado mas não obtive sucesso", novamente no âmbito de operações aleatórias.

Figura 39: Produção escrita E1340

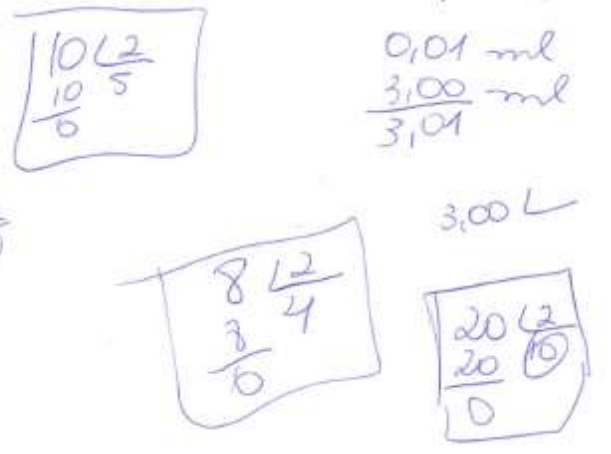

Fonte: Arquivo pessoal da pesquisadora 
Figura 40: Produção escrita E1314

$$
\begin{aligned}
10+10 & =20 \\
\text { Unidade de } 0,01 \mathrm{ml} & - \\
-0,30 & \frac{0,20}{0,10}
\end{aligned}
$$

Fonte: Arquivo pessoal da pesquisadora

Figura 41: Produção escrita E1301

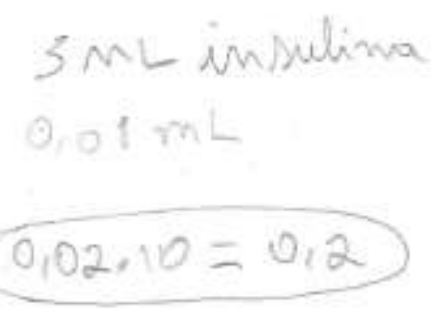

Fonte: Arquivo pessoal da pesquisadora

Figura 42: Produção escrita E1320

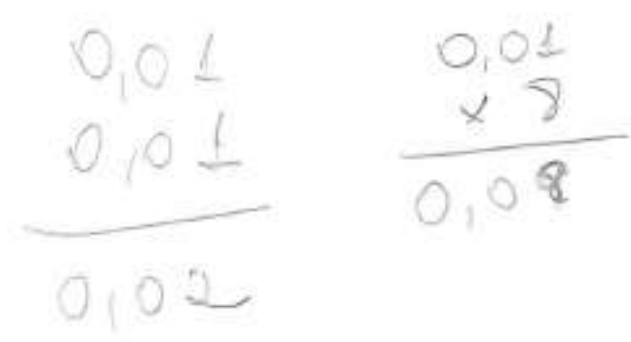

Fonte: Arquivo pessoal da pesquisadora

Apesar de o problema apresentar um contexto real, como a dosagem de aplicação de insulina, os alunos ainda não conseguiram compreender e interpretá-la adequadamente. De uma forma mais geral, observou-se que grande parte dos alunos 
estavam confusos quanto ao que deveriam fazer, como proceder ou que estratégia utilizar.

É importante que o sujeito que se propõe em resolver um problema pense em como se vai resolvê-lo, se questionando o que significa esse número encontrado em cada procedimento realizado. Assim, é essencial que o aluno durante a execução observe o que significa cada resultado que encontrou: o resultado se traduz as unidades de insulina que ele deve tomar? Ou, é a quantidade de aplicações? Esse dado encontrado está expresso em que unidade de medida (em dias, horas, $\mathrm{ml}$ etc.)?

Essa questão solicitava que o aluno indicasse qual o número máximo de aplicações por refil que o paciente poderá utilizar com a dosagem prescrita. Ao ler o questionamento, podemos entender que ele pede quantas vezes podemos utilizar 0 referido refil, sendo assim espera-se que o resultado seja algo como $X$ vezes ou $X$ aplicações. Um aluno propôs que o número máximo de aplicações seriam $1000 \mathrm{ml}$, não demonstrando uma criticidade na resposta obtida, no que se refere a unidade de medida esperada, bem como no valor encontrado, pois se o refil continha $3 \mathrm{ml}$ de insulina é incompatível que o resultado seja $1000 \mathrm{ml}$. Situação semelhante ocorre com o participante 21 , que registrou a resposta como $0,05 \mathrm{ml}$.

Figura 43: Produção escrita E1316

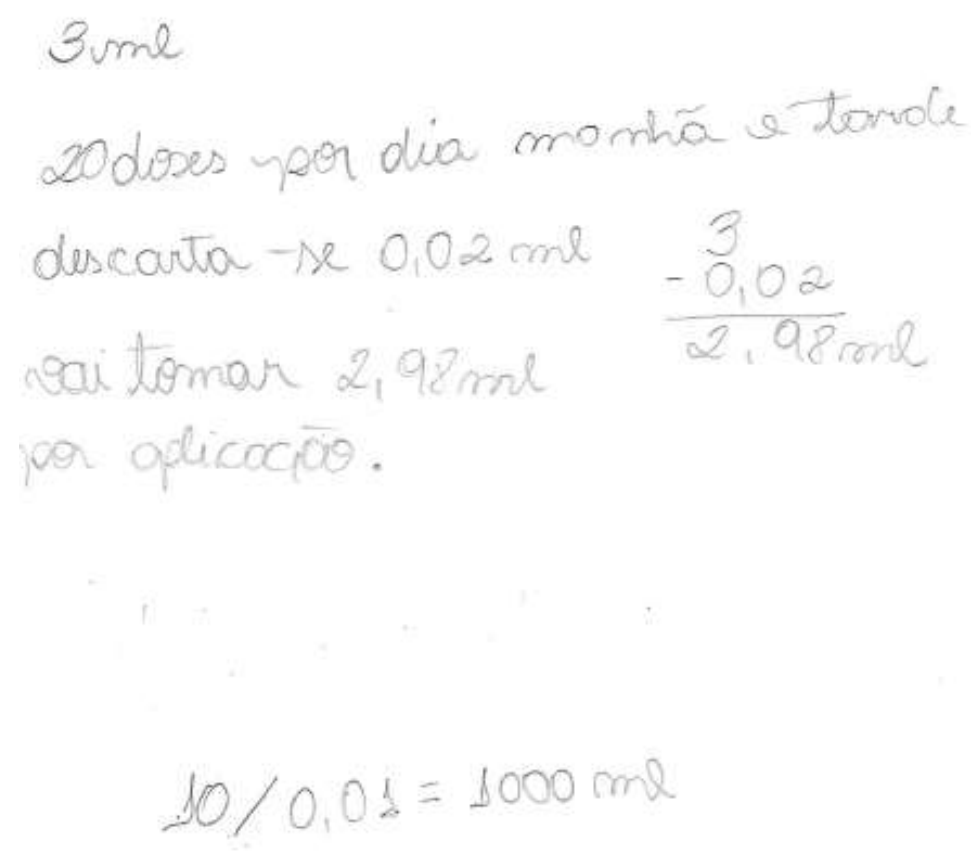

Fonte: Arquivo pessoal da pesquisadora 
Outro aluno 35 registrou a seguinte resposta: "60 refil serão utilizados com $3 \mathrm{ml}$ de insulina em cada", ele considerou $3 \mathrm{ml}$ como a dosagem, sendo que é o refil tem 3 $\mathrm{ml}$, demonstrando não ter compreendido corretamente a questão proposta:

Figura 44: Produção escrita E1335

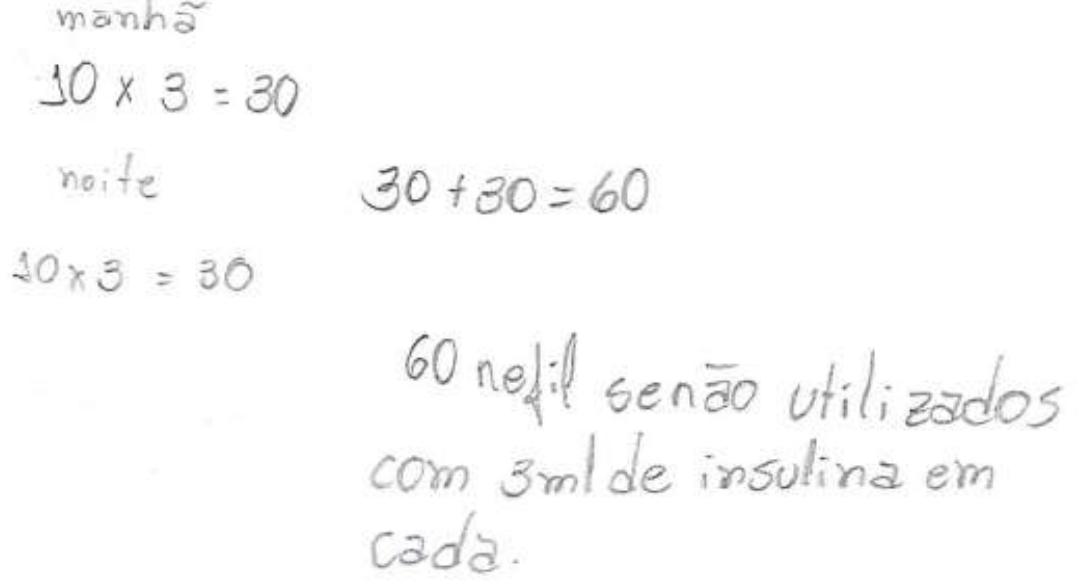

Fonte: Arquivo pessoal da pesquisadora

As respostas produzidas pelos alunos levam a crer, por um lado, que eles não exercitam a reflexão acerca dos valores encontrados, analisando-os a fim de verificar se são apropriados, plausíveis ou absurdos. Por outro lado, tais respostas também podem ser interpretadas como uma possível falta de envolvimento com a tarefa, não a considerando como relevante ou significativa, de modo a apenas produzir algum resultado para se ver livre da atividade. Em ambos os casos, faz-se necessário que os docentes e a escola como um todo reflita acerca das motivações e interesses dos estudantes a fim de orientar o trabalho pedagógico de forma a favorecer as aprendizagens.

\subsubsection{Segunda Atividade Individual}

O problema não rotineiro da segunda atividade foi selecionado entre os itens da prova da OBMEP realizado em 2014. O item tem o seguinte enunciado: 
Guilherme precisa chegar em 5 minutos ao aeroporto, que fica a $5 \mathrm{~km}$ de sua casa. Se nos 2 primeiros minutos seu carro andar a uma velocidade média de $90 \mathrm{~km} / \mathrm{h}$, qual é a menor velocidade média que ele terá que desenvolver nos próximos 3 minutos para não chegar atrasado no aeroporto?

Conforme Tabela 5, 5 alunos apresentaram solução válida para o problema. Destes alunos, 2 tiveram propostas de resolução semelhantes, enquanto os demais conduziram raciocínios diferentes uns dos outros.

O aluno 39 montou uma regra de 3 para converter 2 minutos para hora e multiplicou esse valor por 90 para encontrar a distância que foi percorrida no primeiro momento. Em seguida destaca o que realizou: "montei uma expressão para achar a velocidade média" (E2339) obtendo a equação $0,05^{*} x=2,03$ na qual o tempo foi multiplicado pela velocidade para obter a distância que faltava, não utilizando a tradicional fórmula de velocidade média ( $v$ = distância/tempo), mas modelando uma equação para expressar essa situação.

Figura 45: Produção escrita E2339.

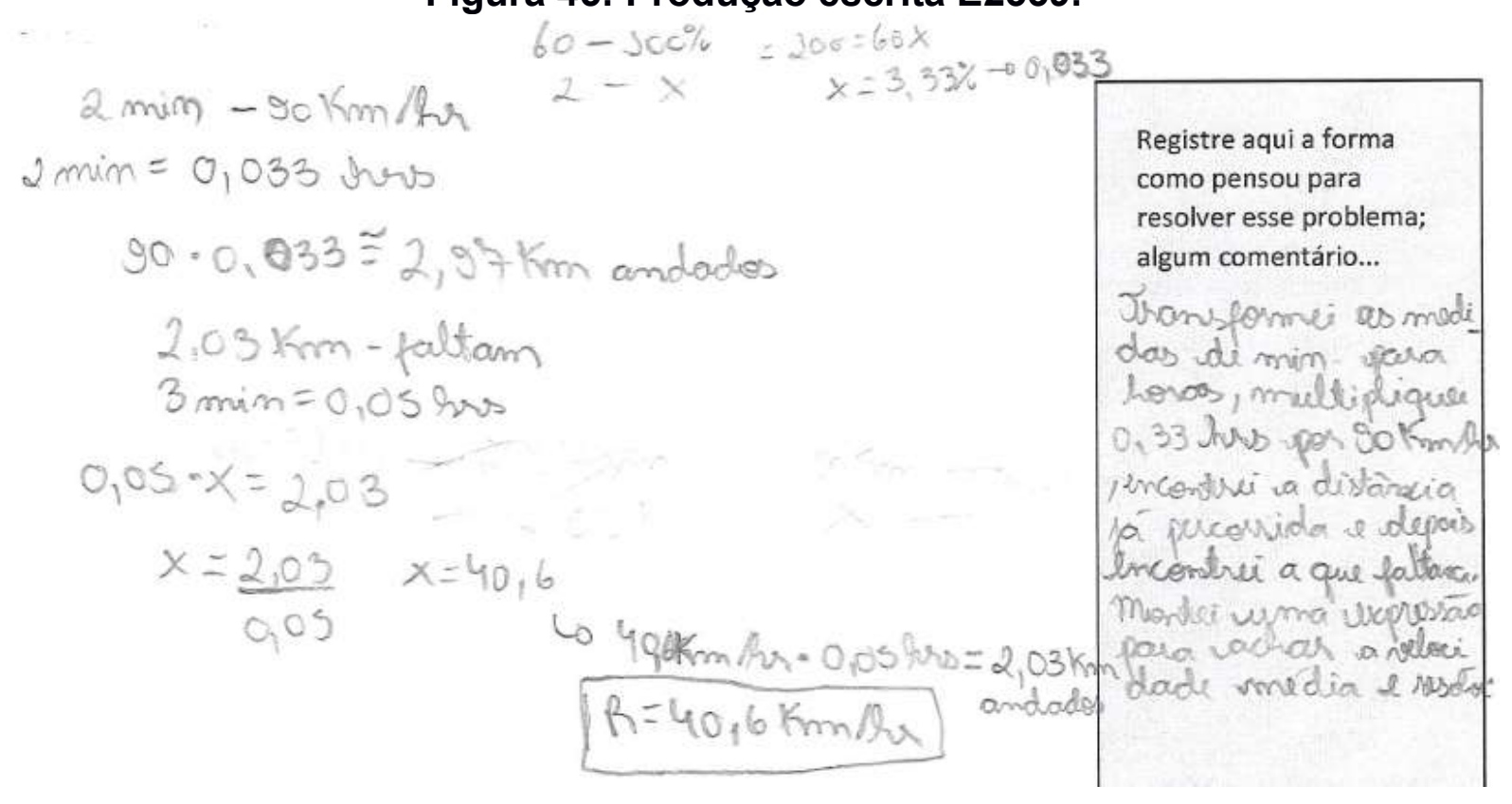

Fonte: Arquivo pessoal da pesquisadora

A forma de resolução proposta pelo aluno 13 foi semelhante ao aluno 12 , embora esse último tenha realizado os cálculos de maneira mais organizada, 
indicando o que significava cada valor, colocando as unidades de medida referente aquele resultado, o que pode ser uma característica que tende a facilitar o processo de resolução evitando que o aluno se perca no meio do processo. Ao indicar a que se refere o valor encontrado e a sua respectiva unidade de medida, fica mais fácil perceber qual a próxima operação deve ser feita para encontrar o resultado final, como por exemplo, ao encontrar o valor $0,666 \mathrm{~km} / \mathrm{m}$ o aluno consegue perceber mais facilmente que deverá transformar esse valor para $\mathrm{km} / \mathrm{h}$.

Figura 46: Produção escrita E2312.

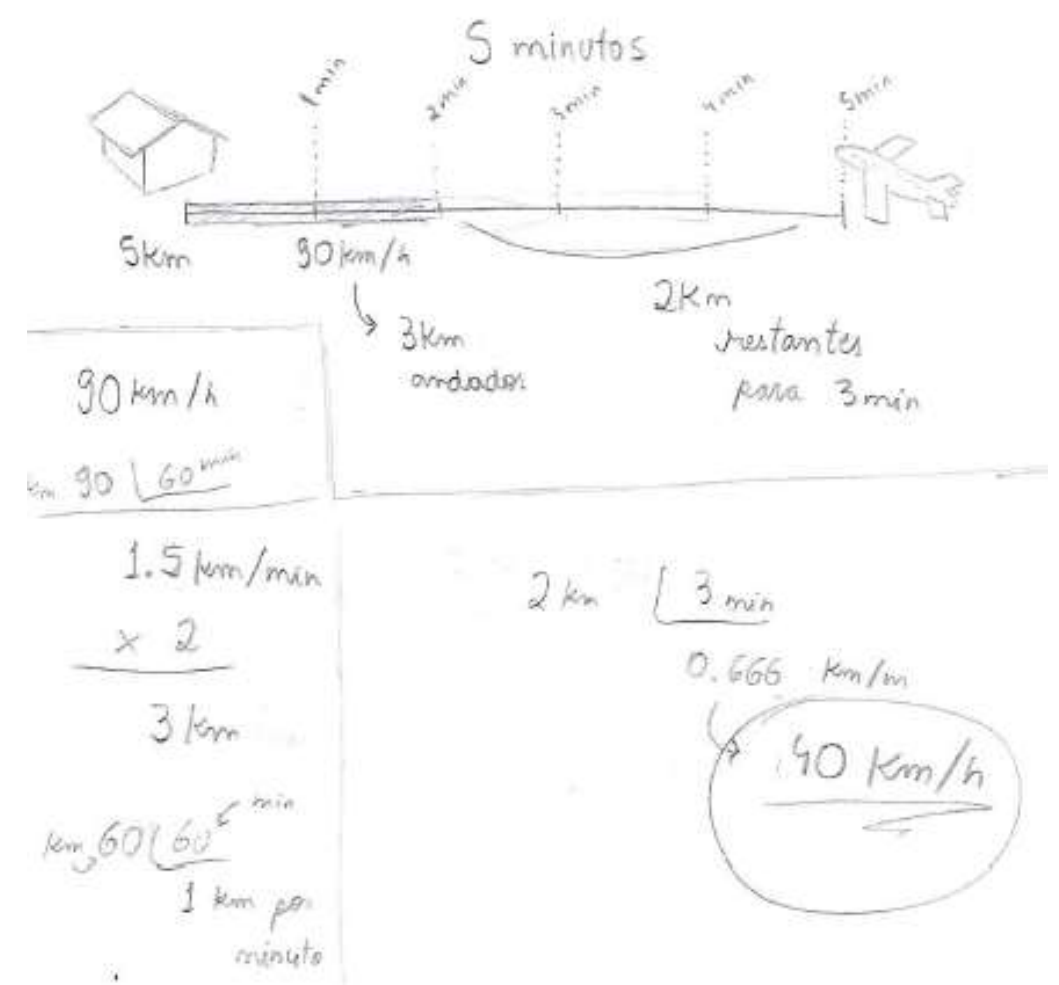

Fonte: Arquivo pessoal da pesquisadora

Ambos os alunos fizeram um registro gráfico para ilustrar a resolução do problema. O aluno 13 propôs um esboço de uma tabela relacionando o tempo e a distância, já o 12 realizou um desenho para ilustrar a situação. Essas formas de registro geralmente são utilizadas para facilitar a compreensão do sujeito que se propõe a resolver um problema como destacado anteriormente junto aos alunos no momento de feedback. Vale destacar também que os dois utilizaram a fórmula da 
velocidade média ao dividir $2 \mathrm{~km}$ por 3 minutos e multiplicaram o resultado final por 60 para alcançar o equivalente em hora.

Já o aluno 4, que realizou diversos cálculos de forma desorganizada e confusa, embora tenha obtido, ao final, o resultado correto.

Figura 47: Produção escrita E2304.

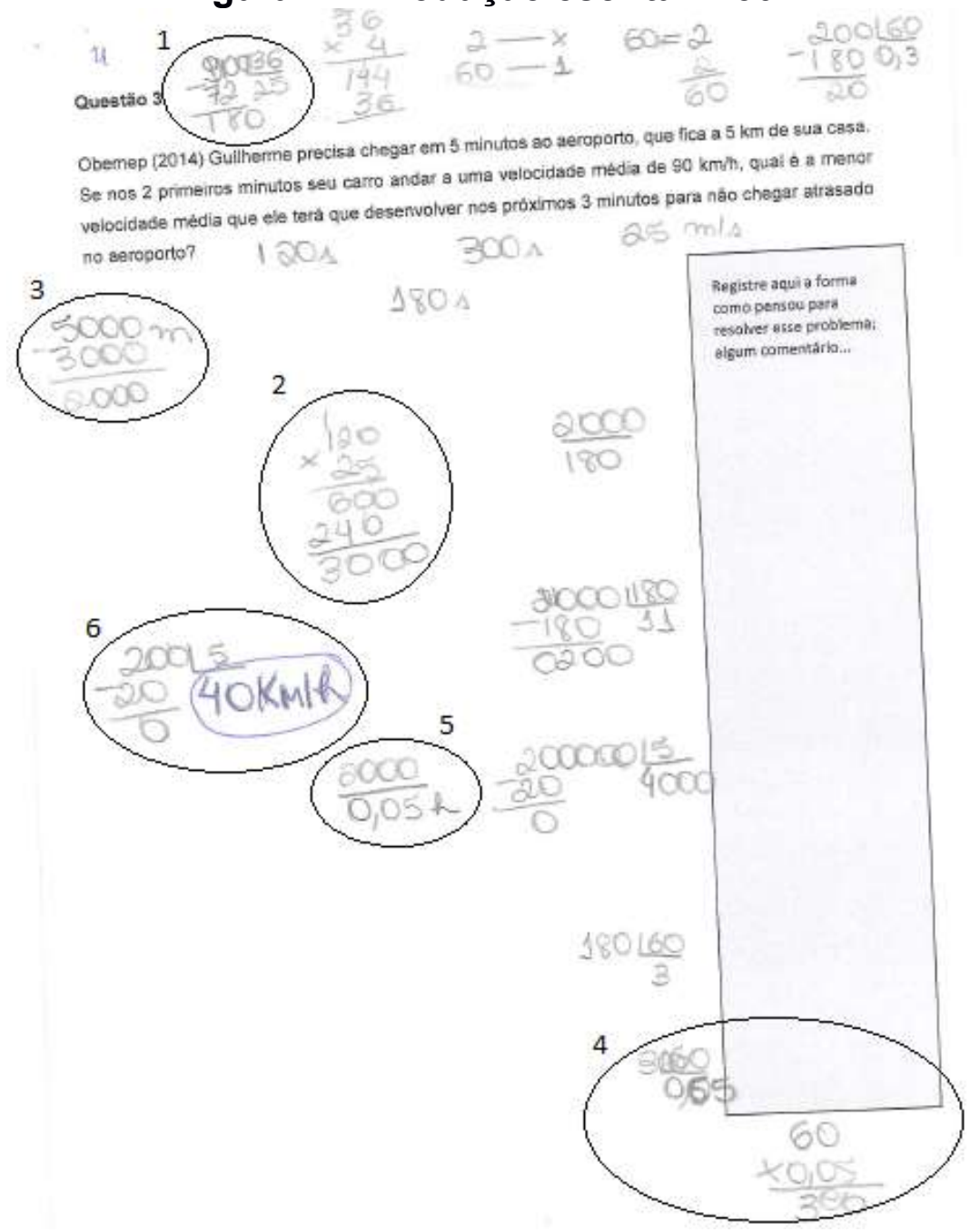

Fonte: Arquivo pessoal da pesquisadora

Os principais cálculos para a resolução desse problema foram destacados para facilitar o entendimento do mesmo: a) transformou os $90 \mathrm{~km} / \mathrm{h}$ para $25 \mathrm{~m} / \mathrm{s}$. b) como havia percorrido 2 minutos a essa velocidade multiplicou 120 por 25, encontrando 3000 metros percorridos. c) subtraiu os 3000 metros dos 5000 que teria que percorrer para encontrar o que faltava a ser percorrido. d) transformou os 3 minutos que faltavam para horas. e) realizou uma tentativa de calcular a velocidade média, mas 
percebeu que estava incorreta, f) fez a divisão de $2 \mathrm{~km}$ por 0,05 h para encontrar a velocidade média, para facilitar a divisão multiplicou os valores por 100 .

O aluno realizou outros cálculos até obter o resultado correto demonstrando que realizou algumas tentavas até conseguir resolver a questão, esse fator também pode demonstrar uma falta de estratégia inicial para a resolução do problema, onde o aluno pode não ter pensado na forma de resolução como um todo, traçando os "passos" e operações que deveriam ser realizados, mas decidindo o que fazer em seguida enquanto realizava as resoluções.

O aluno 29 também transformou os valores para metros e segundos, realizando inicialmente os cálculos de uma forma semelhante ao aluno 4, determinando o valor da velocidade média do segundo trecho em $\mathrm{m} / \mathrm{s}$ e apenas no final realizando a conversão de $\mathrm{m} / \mathrm{s}$ para $\mathrm{km} / \mathrm{h}$. Não há justificativa por parte do aluno para a transformação dos dados para segundos, vale destacar que não havia necessidade para tal conversão.

Um aluno teve uma resposta parcialmente correta, demonstrando ter entendido o contexto do problema. O aluno cometeu um equívoco no final na montagem da regra de 3 ao relacionar as grandezas de uma forma incorreta. Ele relacionou uma coluna com os km e outra coluna com horas, como o x estava na coluna de km, então a resposta deveria ser em $\mathrm{km}$, mas o aluno considerou a resposta como $\mathrm{km} / \mathrm{h}$, outro fato é que ele relacionou a velocidade que a pessoa tinha percorrido na primeira parte com a velocidade da segunda parte.

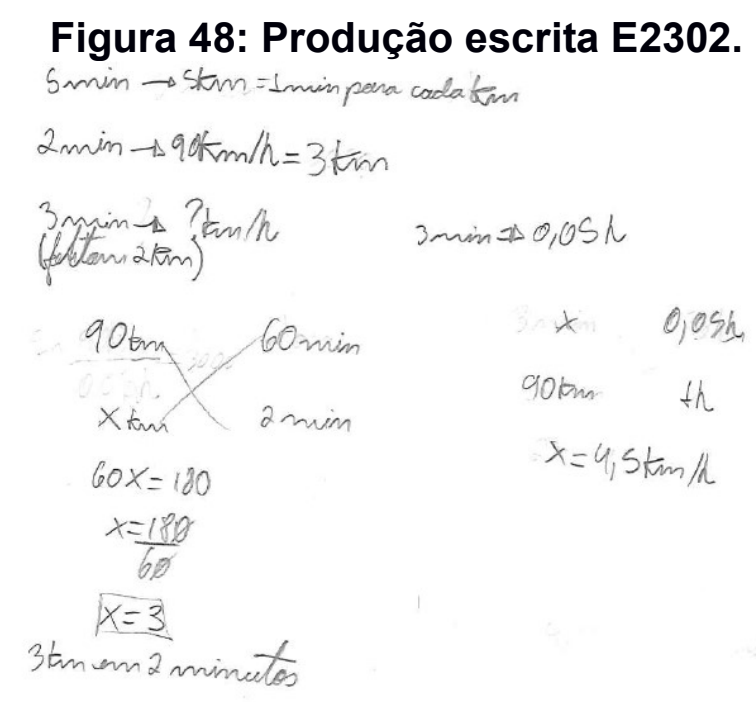

Fonte: Arquivo pessoal da pesquisadora 
Outros 6 participantes também usavam os $90 \mathrm{~km} / \mathrm{h}$ como referência para a velocidade do segundo trecho, dessa forma, eles consideraram que esse valor, de alguma forma, seria aplicado também nos últimos 3 minutos. Ao refletirmos sobre a pergunta que é feita na questão: qual é a menor velocidade média que ele terá que desenvolver nos próximos 3 minutos para não chegar atrasado no aeroporto? não faria sentido utilizar essa velocidade média de $90 \mathrm{~km} / \mathrm{h}$ como referência para esse cálculo pois qual a razão de em se calcular a velocidade média dos últimos 3 minutos sendo que eles já consideram a velocidade média de $90 \mathrm{~km} / \mathrm{h}$ ? Esse questionamento crítico parece não ter sido levantado por eles.

O aluno 34 calculou quantos quilômetros ele percorreria por minuto (90 km/h*2 minutos $/ 60$ minutos $=3 \mathrm{~km} / 2$ minutos $=1,5 \mathrm{~km}$ ), descobrindo $1,5 \mathrm{~km}$ a cada 2 minutos. Vale registrar que existe uma divergência entre o que o participante registrou na parte da resolução e o que fez no comentário explicitando o seu raciocínio, destacando que seria 1,5 km por minuto, por serem $5 \mathrm{~km}$ então "o resultado seria esses noventa multiplicado por 3 mais 0,5 km" pois seria necessário multiplicar 1,5 por 3 e somar 0,5 $\mathrm{km}$ para se obter os $5 \mathrm{~km}$ propostos no problema, considerando então que durante todo o percurso a referência da velocidade média são os $90 \mathrm{~km} / \mathrm{h}$. O resultado foi obtido pelo cálculo de $90 \mathrm{~km}+90 \mathrm{~km}+30 \mathrm{~km}=300$, como o aluno já havia registrado que teria que multiplicar o 90 por 3 , fica subentendido que ele esqueceu de registrar uma parcela do número 90 , mas obtendo o resultado desejado de $300 \mathrm{~km} / \mathrm{h}$, demonstrando a ausência de criticidade quanto ao valor da velocidade encontrada neste contexto. 
Figura 49: Produção escrita E2334.

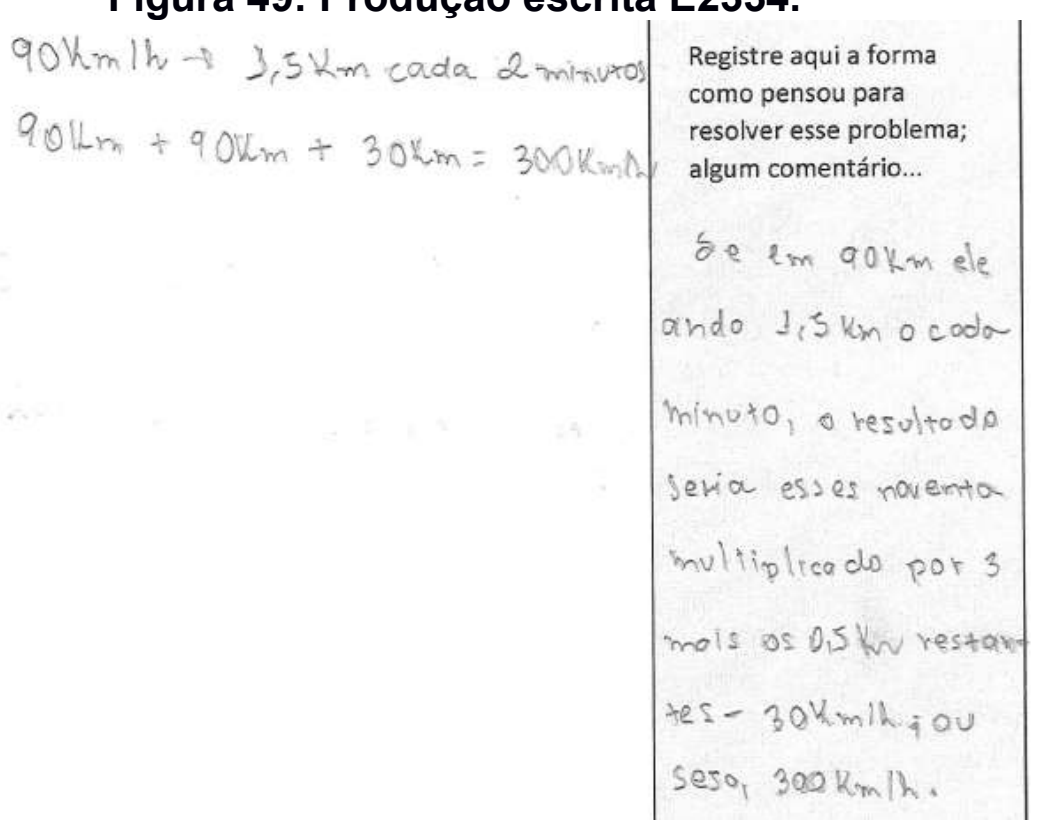

Fonte: Arquivo pessoal da pesquisadora

Ele demonstrou que tinha certo conhecimento relacionado à razão e proporção ao realizar essas contas, ao considerar que $90 \mathrm{~km} / \mathrm{h}$ correspondia a $1,5 \mathrm{~km}$ então inferiu que $30 \mathrm{~km} / \mathrm{h}$ seria correspondente a $0,5 \mathrm{~km}$, considerando equivocadamente a relação desses números como grandezas diretamente proporcionais. Nesse caso, apesar de ter demostrado esse conhecimento ele se enganou ao relacionar esses valores pois observou apenas os números sem considerar as grandezas e o contexto associado aos mesmos. Os $90 \mathrm{~km} / \mathrm{h}$ é a velocidade média que manteve durante 2 minutos, dessa forma, não se pode considerar que com em $0,5 \mathrm{~km}$ tinha uma velocidade de $30 \mathrm{~km} / \mathrm{h}$, em 1,0 km a velocidade era $60 \mathrm{~km} / \mathrm{h}$ e em $1,5 \mathrm{~km}$ de $90 \mathrm{~km} / \mathrm{h}$, demonstrando assim certa dificuldade no entendimento conceito de velocidade média.

Apesar de aparentemente ter uma estratégia para resolução, demonstrada ao explicar o passo a passo de seu raciocínio no espaço para os comentários, o aluno não conseguiu resolver o problema, provavelmente por não ter compreendido o mesmo.

Das dificuldades demonstradas nas resoluções dessa questão que foram possíveis observar (fragilidade no conceito de velocidade média, relacionamento de grandezas com unidades diferentes, utilizar a velocidade da primeira parte com o tempo da segunda parte, desmotivação, dentre outros), pode-se perceber que um dos principais fatores que dificultaram que os alunos acertassem foi a compreensão do 
contexto do problema, vez que não conseguiram interpretar os dados que foram fornecidos.

O aluno 16 realizou a seguinte operação: $90-3=87 \mathrm{~km} / \mathrm{h}$, já o aluno 30 aparentemente realizou a multiplicação de alguns valores que eram apresentados no enunciado, $5^{\star} 5^{\star} 3=75$, sem registrar a forma de raciocínio.

O aluno 25 além de ter demonstrado não ter entendido a questão ao realizar a divisão entre os $90 \mathrm{~km} / \mathrm{h}$ com os 3 minutos restantes para chegar ao aeroporto, relacionou a velocidade desenvolvida na primeira parte com o tempo da segunda, ele também não observou que estava trabalhando com unidades de medidas diferentes ao se dividir $90 \mathrm{~km} / \mathrm{h}$ por 3 minutos.

Vale se realizar algumas observações acerca da resolução do participante 31. O mesmo registrou que "em 2 minutos andou $90 \mathrm{~km} / \mathrm{h}$ ", observe-se que em certo tempo se desloca certa distância, como por exemplo em 2 minutos andou 90 km.

Figura 50: Produção escrita E2331.

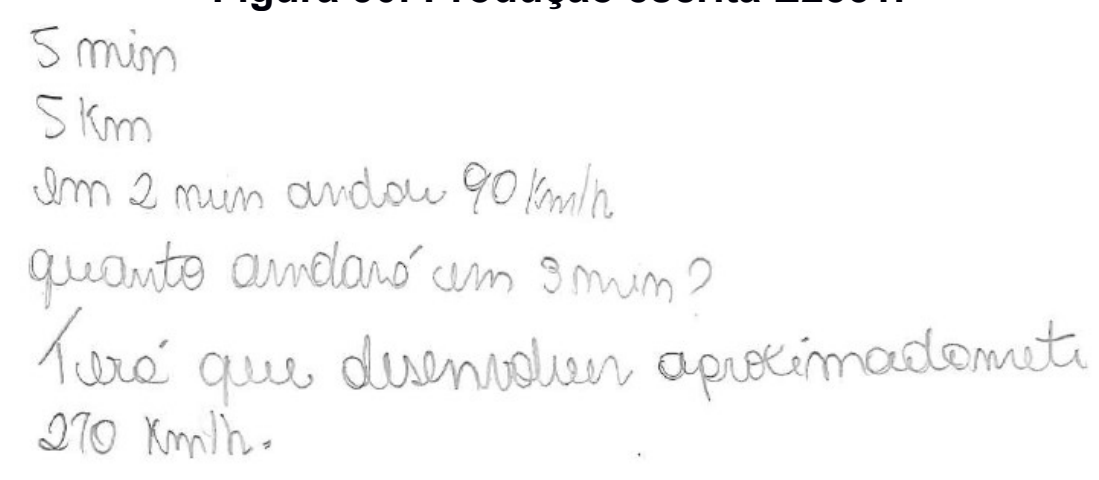

Fonte: Arquivo pessoal da pesquisadora

Levando em consideração as afirmações registradas pelo aluno, em sua resolução ele multiplicou 90 por 3 para encontrar a resposta, mas se ele havia registrado anteriormente que "em 2 minutos andou $90 \mathrm{~km} / \mathrm{h}$ " (E2331) para se encontrar o valor de 3 minutos não bastaria multiplicar o 90 por 3 , ao realizar o cálculo dessa forma ele considerou que em 1 minuto andaria a $90 \mathrm{~km} / \mathrm{h}$ e não em 2 minutos como ele mesmo registrou, demonstrando assim ter uma fragilidade no conceito de razão e proporção

Outra questão a se ressaltar é o questionamento realizado por ele que deveria ser respondido: "quanto andará em 3 minutos?". Ao realizar o questionamento dessa forma dá a impressão que tem que se descobrir a distância que será percorrida e não 
a velocidade média que teria de ser desenvolvida nesses 3 minutos como solicitava a questão.

Conforme sugerido no momento de feedback realizado junto aos alunos na semana anterior a essa atividade, um participante esboçou um desenho para auxiliar na compreensão do problema. Entretanto, a ilustração não foi o suficiente para que ele conseguisse desenvolver a questão, apenas realizando o desenho e não dando prosseguimento no cálculo.

Figura 51: Produção escrita E2342.

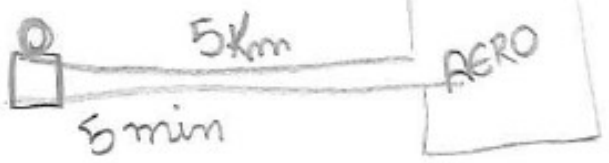

Fonte: Arquivo pessoal da pesquisadora

O aluno 33 também começou a resolução apenas separando os primeiros dados apresentados no problema, mas não efetuando cálculo algum. Esses alunos demonstraram ter tentado começar a resolver a questão, mas não conseguiram dar prosseguimento na resolução provavelmente por não saberem como proceder para resolver.

O aluno 38 pensou que como a velocidade média era de $90 \mathrm{~km} / \mathrm{h}$ nos dois primeiros minutos então em 2 minutos era $180 \mathrm{~km} / \mathrm{h}$, para os 3 últimos minutos a velocidade seria então seria 180/3, relacionando duas unidades de medidas diferentes: $\mathrm{km} / \mathrm{h}$ com minutos, quando essas deveriam ser $\mathrm{km} / \mathrm{h}$ com hora. $\mathrm{O}$ aluno buscou relacionar a velocidade encontrada na primeira parte do percurso numa espécie de proporção da velocidade nos outros 3 minutos, dividindo esse valor por 3 obtendo o resultado igual a 33. Vale considerar ainda que, ao realizar a divisão de 180 por 3 igual a 33, o aluno demonstra não possuir domínio do algoritmo da divisão. Essa dificuldade na resolução das contas relacionadas às quatro operações básicas da aritmética já foi destacada anteriormente nesse capítulo.

As resoluções dos alunos 31 e 38 podem indicar uma fragilidade relacionada ao conceito de velocidade média. Esse tipo de resolução demonstra que os alunos não entenderam a questão ou não dominam o conceito envolvido. 
O aluno 21 indicou o cálculo que deveria ser realizado, 180/5, mas deixou em branco a resposta provavelmente por não ter conseguido realizar a divisão ou por não acreditar na estratégia de resolução por ele escolhida. O participante 40 também demonstrou certa dificuldade para realizar a divisão 90/5, apesar de ter acertado o resultado dessa divisão, ele registrou a tabuada de 5 para auxiliar nos cálculos, evidenciando dificuldade em realizar cálculos mentais envolvendo a multiplicação. Ressalta-se, entretanto, que o estudante conseguiu elaborar uma estratégia para obter o resultado desejado, o que é muito importante.

Vale destacar que apenas 3 respostas se repetiram 18, 45 e 135, sendo duas vezes cada uma delas. Os alunos que obtiveram a resposta igual a 135 realizaram corretamente a regra de 3 que montaram, mas não relacionaram corretamente as grandezas; já os que tiveram o resultado igual a 18, ambos resolveram da mesma forma 90/5; e, os que registraram uma resposta igual a 45 tiveram formas de resolução diferentes.

O aluno 11 destaca que percebeu que "a lógica do meu raciocínio é multiplicar os km de distância da casa pelos km que já percorreu" (E2311), apesar de registrar que ele multiplicaria as distâncias, que estão em $\mathrm{km}$, ao realizar o cálculo ele registra que a unidade de medida de 90 é $\mathrm{km} / \mathrm{h}$, além disso ainda considera equivocadamente a unidade de medida do 5 também em $\mathrm{km} / \mathrm{h}$.

Figura 52: Produção escrita E2311.

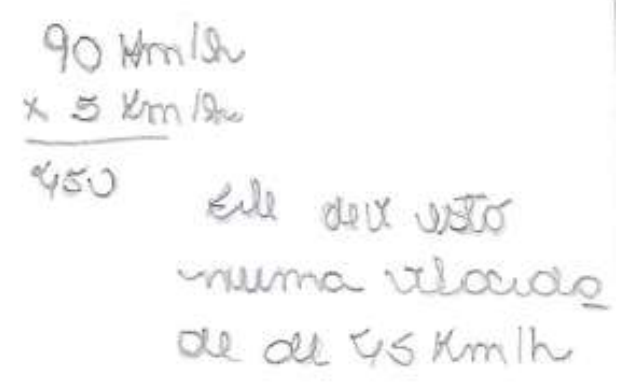

Fonte: Arquivo pessoal da pesquisadora

No momento de feedback foi destacado que seria interessante que eles dessem um significado ao número que encontraram como resposta, não registrandoo de forma isolada, sem se referir ao que ele significa no contexto da questão, bem como sem refletir se aquele resultado tem sentindo naquele contexto. Foi isso que 
esse aluno fez, registrou uma resposta mais completa. Apesar de ter encontrado o resultado final como 450 , ele registrou como resposta final que "ele deve estar numa velocidade de $45 \mathrm{~km} / \mathrm{h}$ " (E2311) não apresentando nenhum cálculo que justificasse como o 450 foi reduzido a 45 . O comentário que ele registrou, como apresentado anteriormente, também não mostra que realizou nenhuma outra operação, somente "multiplicar os km de distância da casa pelos km que ele já percorreu" (E2311), podese inferir que o participante no momento de registrar a resposta pensou que a resposta com o número 450 ficaria irreal ao considerar que ele deve estar numa velocidade de $450 \mathrm{~km} / \mathrm{h}$, registrando como resposta final o $45 \mathrm{~km} / \mathrm{h}$ que faria mais sentido.

Situação semelhante também pode ser observada na resolução do participante 32 , que realizou uma multiplicação de $180^{*} 25$ para obter a resposta, mas quando fez o registro escreveu " $45 \mathrm{~km} / \mathrm{h}$ para não chegar atrasado ao aeroporto" (E2332) pois colocar que a pessoa teria que ter uma velocidade média de $4.500 \mathrm{~km} / \mathrm{h}$ seria absurdo, ou o participante não obteve êxito ao realizar a multiplicação dos valores.

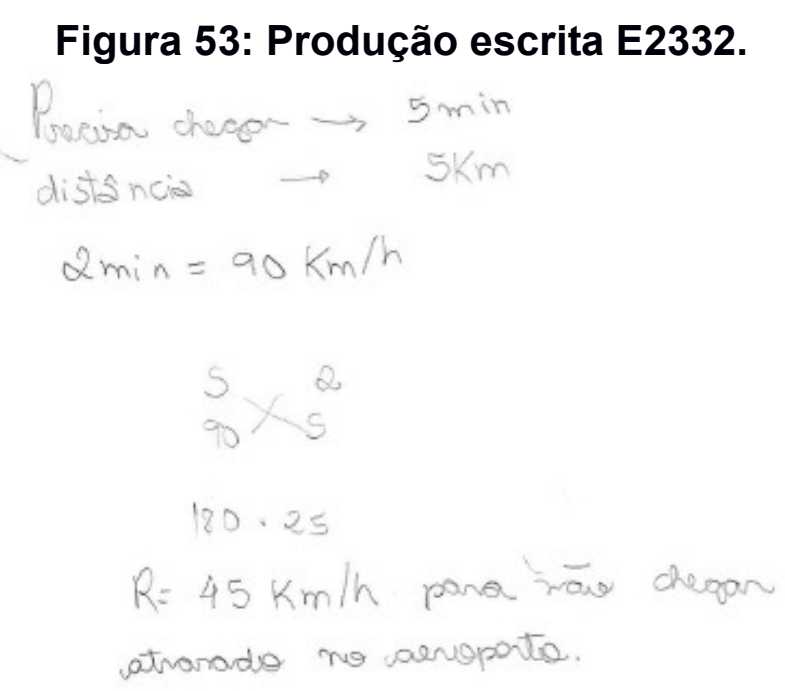

Fonte: Arquivo pessoal da pesquisadora

Ao montar a regra de 3 , esse participante não colocou o valor de $\mathrm{x}$, registrando 4 valores que foram retirados do problema. Ele efetuou uma multiplicação cruzada demonstrando ter certo conhecimento de como se resolver uma regra de 3 , ao aplicar a propriedade fundamental das proporções para resolver a questão, mas equivocouse com a finalização dos cálculos. Vale destacar que esse aluno acertou os exercícios da atividade individual anterior a essa e dessa forma pôde-se perceber que quando 
diante de um exercício relacionado a razão e proporção já estruturado ele obteve sucesso resolvendo corretamente utilizando a propriedade fundamental das proporções, mas demonstrou certa dificuldade com a interpretação do problema para associar as grandezas e estruturar da regra de 3.

Dos 31 alunos que participaram dessa atividade, apenas 4 utilizaram a propriedade fundamental das proporções para tentar resolver o problema. Um acertou parcialmente a resolução e os demais não alcançaram o resultado esperado. Desses, apenas o aluno 32, conforme figura 53 , não conseguiu resolver com sucesso a regra de 3 que estruturou, como já explicitado anteriormente. Já os demais resolveram corretamente a regra de 3 , ou seja, a maior parte deles demonstrou que sabe como resolvê-la, sendo que o obstáculo para se obter o resultado esperado se encontrou na interpretação do enunciado e em como relacionar os dados presentes no problema. Vale destacar que nenhum dos alunos que acertaram fizeram o uso de regra de 3 para resolver o problema.

O aluno 7 comentou que fez "regra de $x$, não sei se está certa", sendo que a regra de $x$ que o aluno se refere é a propriedade fundamental das proporções, a qual resolveu de forma correta, relacionando de forma equivocada os valores entre si, obtendo dessa forma o resultado incorreto. Esse aluno também demonstrou desmotivação ao desenhar um rosto triste no final da frase, restando ao leitor dessa produção uma interpretação de baixo autoconceito por parte do estudante em relação à matemática.

A conversão das unidades de medidas, como de quilômetros para metros, ou horas para minutos por exemplo, não parece ter sido um grande problema, vez que grande parte dos alunos que optou por converter alguma unidade tive sucesso, embora um problema recorrente foi a relação entre unidades de medidas diferentes, por exemplo dividir km/h por minutos, como já destacado em algumas resoluções apresentadas.

\subsubsection{Atividade em Grupo}

Para o problema não rotineiro da atividade em grupo optou-se por repetir um problema que havia sido aplicado na atividade anterior, visando comparar as estratégias de resolução desenvolvidas para o mesmo problema quando resolvido de 
forma individual e quando em grupo. Dessa forma repetiu-se a questão da ida ao aeroporto retratada anteriormente. Apenas um grupo acertou a resolução do problema. Dos 5 alunos que acertaram esse problema na atividade individual, 3 estavam atuando como observadores dos grupos A, B e C, portanto não participaram do processo de resolução dessa questão, e os outros dois participaram do processo de resolução junto aos grupos $\mathrm{D}$ e $\mathrm{H}$.

Dos 8 grupos, apenas um acertou o resultado da questão (grupo H) e outro (grupo D) teve um resultado parcialmente correto, os demais não obtiveram sucesso no processo de resolução. Vale destacar que esses dois grupos que tiveram a resposta correta ou parcialmente correta, foram grupos em que um dos participantes havia acertado a questão quando resolveram a atividade individualmente. Isso indica, aparentemente, que não houve uma melhoria no resultado ao se comparar o processo de resolução individual com o realizado em grupo.

Cada grupo apresentou uma resposta diferente, em função disso, optou-se por detalhar a forma de resolução de cada um deles.

\section{- Grupo A}

O observador desse grupo registrou que "os participantes tentaram resolver por um momento, mas não conseguiram. Na segunda tentativa eles multiplicaram os três primeiros minutos que faltavam pela velocidade que ele andou nos 2 minutos anteriores para descobrir o resultado" (OQ3A) obtendo o valor 270. Vale destacar que essa resolução foi a mesma resolução proposta pelo participante 31 , que fazia parte desse grupo, na segunda atividade individual.

\section{Figura 54: Produção escrita G3A.}

Fonte: Arquivo pessoal da pesquisadora 


\section{- Grupo B}

O observador desse grupo registrou que "as participantes pularam essa questão. Infelizmente não conseguiram resolver a questão" (OQ3B). Elas chegaram a iniciar um raciocínio transformando $90 \mathrm{~km} / \mathrm{h}$ para $1,5 \mathrm{~km} / \mathrm{s}$, mas não finalizaram o processo.

Figura 55: Produção escrita G3B.

$$
\begin{aligned}
& 2 \mathrm{~min}=90 \mathrm{~km} / \mathrm{h}=1,5 \\
& \cong 1,16 \rightarrow 3,48 \mathrm{~km} / \mathrm{h} \rightarrow
\end{aligned}
$$

Fonte: Arquivo pessoal da pesquisadora

- Grupo C

O observador registrou que um participante tentou resolver, depois outros ajudaram, desistiram, voltaram a tentar resolver e realizaram o seguinte cálculo: $90 * 3 / 5=54$. Essa resposta não foi obtida nas resoluções individuais, sendo um processo de resolução novo, construído pelos membros desse grupo. O observador destacou ainda que "os dados não foram anotados e organizados e foram feitas algumas contas aleatórias" (OQ3C).

Figura 56: Produção escrita G3C.

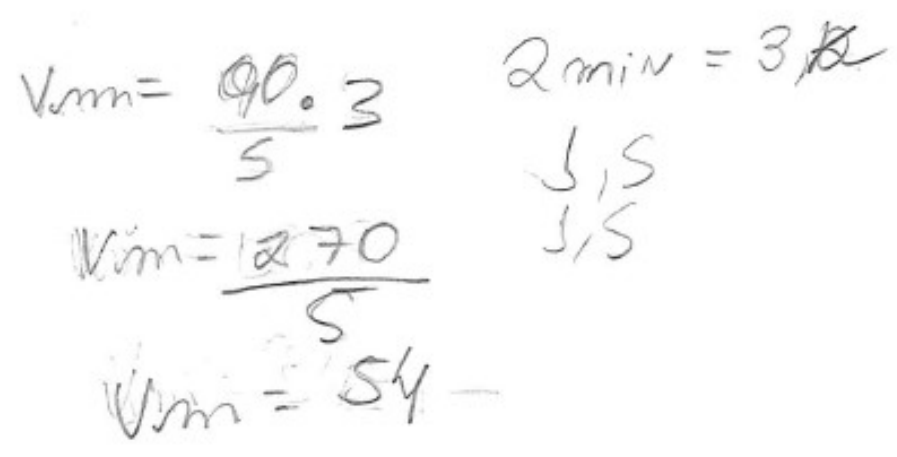

Fonte: Arquivo pessoal da pesquisadora 


\section{- Grupo D}

O resultado $36 \mathrm{~km} / \mathrm{h}$ foi proposto por outro participante na resolução individual (21) que não fazia parte desse grupo. Apesar do resultado ser o mesmo, a forma de resolução foi diferente da proposta pelo participante 21 que realizou 90*2/5.

O observador destacou que grupo não ajudou na resolução da referida questão, sendo que apenas um participante que afirmou que sabia resolver o problema realizou sozinho a resolução do mesmo. O observador desse grupo registrou que "uma pessoa liderou a questão e a resolveu sozinho enquanto as outras 3 resolviam a quarta, pois ele sabia como resolver essa questão" (OQ3D). Essa pessoa, a quem o observador se referiu, era o aluno que acertou essa questão quando realizou a atividade individual (13), embora não tenha obtido sucesso na resolução em grupo.

Figura 57: Produção escrita G3D.

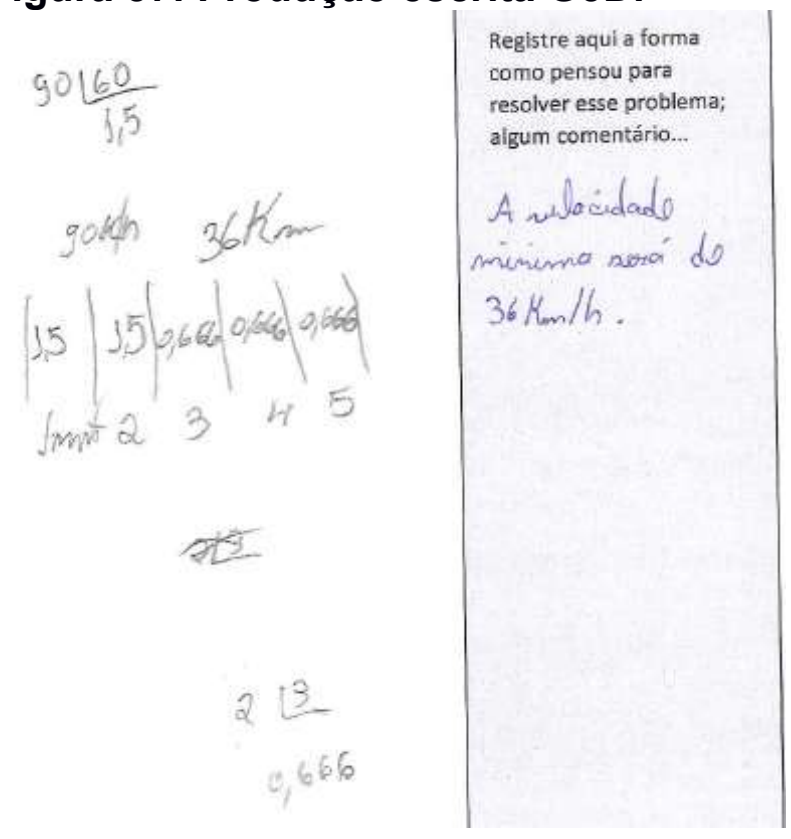

Fonte: Arquivo pessoal da pesquisadora 
Figura 58: Produção escrita E2313.

Fonte: Arquivo pessoal da pesquisadora

Esse participante esboçou uma tabela para organizar o tempo e a distância tanto na atividade individual quanto na atividade em grupo. Ele começou a resolver da mesma forma que da questão individual, mas após realizar a divisão para encontrar a velocidade média ele parece ter se confundido em sua estratégia, não demonstrando saber exatamente o que fazer e chegando ao número $36 \mathrm{~km} / \mathrm{h}$ como resposta, sem registrar os cálculos realizados para a obtenção desse resultado. O que permite supor que o aluno tentou recordar a resposta registrada quando resolveu esse problema anteriormente.

\section{- Grupo E}

O raciocínio foi semelhante ao proposto por outro participante (25) na resolução individual, que não fez parte desse grupo. Eles dividiram os $90 \mathrm{~km} / \mathrm{h}$ pelos 3 minutos que faltavam ser percorridos chegando ao resultado de $30 \mathrm{~km} / \mathrm{h}$, explicando que 
"pegamos a velocidade média e dividimos pelos minutos que faltavam" (G3E), novamente relacionando a velocidade média do primeiro trecho como se fosse a velocidade média do segundo. Além desse equívoco, eles também relacionaram unidades de medidas diferentes ao dividir $90 \mathrm{~km} / \mathrm{h}$ por 3 minutos.

Figura 59: Produção escrita G3E.
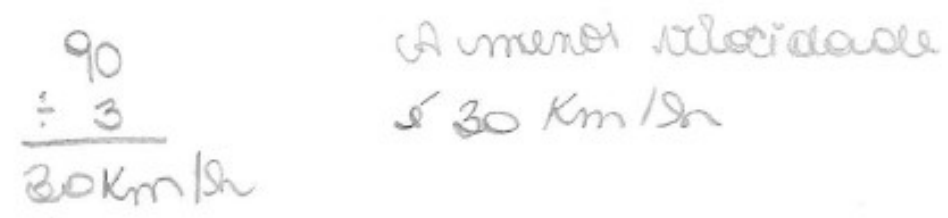

Fonte: Arquivo pessoal da pesquisadora

O observador desse grupo registrou que eles "tiveram um pouco mais de dificuldade para resolver. Uma pessoa desistiu, e as outras continuaram tentando" (OQ3E).

\section{- Grupo F}

A resposta, $135 \mathrm{~km} / \mathrm{h}$, foi a mesma que foi proposta por um participante na resolução individual que fazia parte desse grupo. A forma de resolução foi semelhante, sendo que na atividade individual ele realizou regra de 3 , mas em grupo eles não registraram isso no protocolo. $\mathrm{O}$ observador destaca que eles tentaram resolver usando lógica.

Figura 60: Produção escrita G3F.

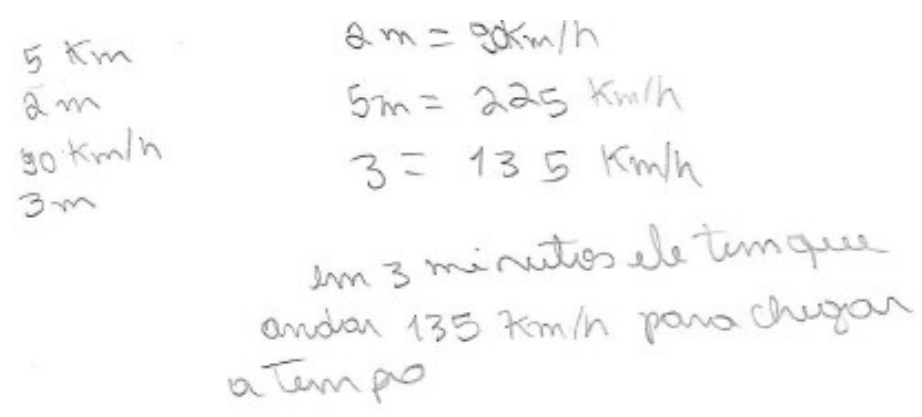

Fonte: Arquivo pessoal da pesquisadora 


\section{- Grupo G}

A resolução e o comentário foram exatamente os mesmos que os propostos na atividade individual pelo participante 27 , o qual fazia parte do grupo. O observador registrou que grupo não ajudou muito a resolver essa questão, sendo que basicamente esse participante resolveu sozinho e "finalizou sem nenhuma divergência do grupo" (OQ3G). Pode-se observar pela fala do observador e pelas resoluções iguais que o grupo não contribuiu muito para o processo de resolução da mesma.

Figura 61: Produção escrita G3G.
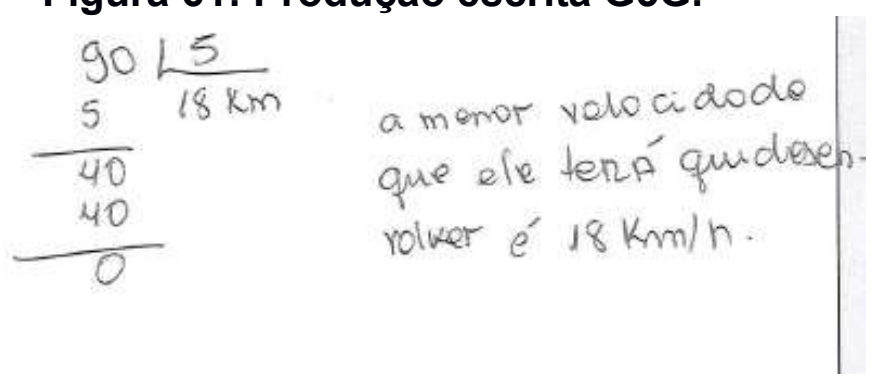

Fonte: Arquivo pessoal da pesquisadora

Figura 62: Produção escrita E2327.
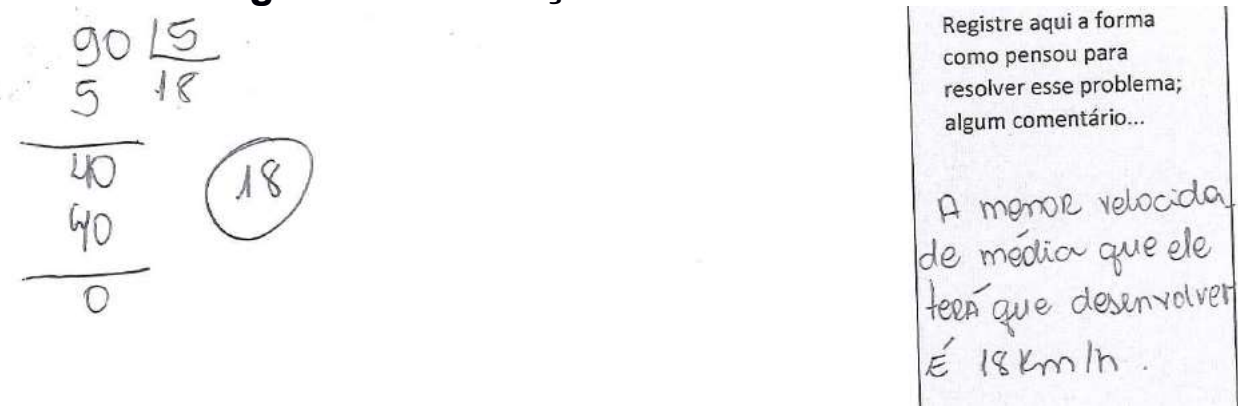

Fonte: Arquivo pessoal da pesquisadora

- Grupo H

O participante 29 , que fazia parte desse grupo, acertou a questão na atividade individual. As resoluções foram semelhantes, mas ao contrário do grupo G, o observador destacou que "dois alunos resolveram e se empenharam para a resolução, fazendo os cálculos e raciocinando" havendo uma interação entre dois participantes para o desenvolvimento das estratégias de resolução da questão. 
Figura 63: Produção escrita G3H.

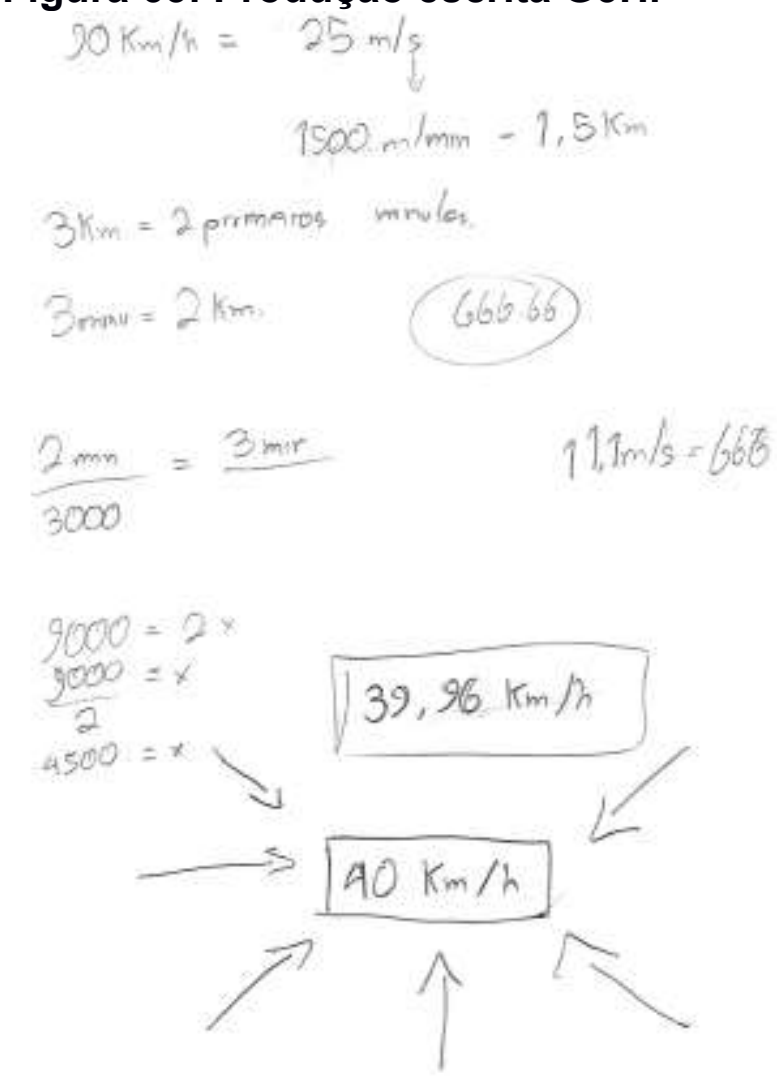

Fonte: Arquivo pessoal da pesquisadora

Como destacado, dois alunos, um que já havia acertado essa questão e o outro que não, se dedicaram para resolvê-la juntos, de modo que aquele sabia resolver ajudou o outro, havendo uma interação entre eles. Diante disse surge um questionamento: será que se fosse solicitado que esse aluno, que antes não havia acertado a questão, a resolvesse sozinho, ele conseguiria acertar? ou pelo menos avançar corretamente no processo de resolução?

Situações como essa reforçam a ideia da importância da interação entre os participantes. Silva (2014, p. 75) destaca a importância dessas interações entre os pares e cooperação entre os estudantes

em que alguns estão em situação de sucesso ou de êxito e outros em situação de fracasso ou de dificuldade na aprendizagem escolar da matemática. Esse grupo de estudante tem como objetivo saber mais e melhor sobre os objetos matemáticos e, nesse sentido, interagem e dialogam a partir situações matemáticas sem que haja predeterminação na direção, no sentido e na forma como circulam os conhecimentos. Assim, ambos podem aprender uns com os outros. 
A troca de experiência vivenciada a partir do grupo em meio a um processo resolutivo de problema matemático pode, em alguns casos, trazer elementos de aprendizagem mais significativos do que aqueles propostos pelo professor e pelo ordenamento e método por ele organizado, ou seja, a conceituação construída a partir da fala dos pares no desenrolar de atividades em grupo pode ser um elemento facilitador no aprender matemática.

Dois grupos (C e D) obtiveram uma resposta que não havia sido registrada anteriormente na atividade individual pelos integrantes do grupo, demonstrando que eles se reuniram para elaborar uma resolução própria do grupo. Os grupos que tinham participantes que acertaram a resolução do problema na segunda atividade individual $(\mathrm{D}$ e H) resolveram seguindo o raciocínio dos participantes que tinham acertado.

Já outros 4 grupos (A, B, F, G) desenvolveram seu processo de resolução baseado na resolução proposta anteriormente na atividade individual por um dos participantes do grupo. Vale destacar que as respostas de todos esses participantes não estavam corretas, diante disso, qual poderia ser a justificativa para o grupo ter optado resolver o problema adotando a resolução de um membro em detrimento a outro tipo de resolução? Qual o critério utilizado para optar pela a forma de resolução de determinado participante sendo que nenhum dos participantes obteve o resultado correto? Talvez essa pessoa tenha demonstrado mais liderança ou maior capacidade de explicar a sua ideia, essas são algumas possibilidades que podem ser levantadas.

Após a análise dessas questões apresentadas, pôde-se perceber que os acertos, de uma forma geral, resultaram do uso das operações de multiplicação e divisão, sendo que poucos alunos optaram por utilizar a regra de 3 para a resolução dos problemas. 
Tabela 7: Resoluções utilizando regra de 3

\begin{tabular}{|c|c|c|c|c|c|c|}
\hline & $\begin{array}{l}\text { Problema } \\
\text { rotineiro } 1\end{array}$ & $\begin{array}{l}\text { Problema } \\
\text { rotineiro } 2\end{array}$ & $\begin{array}{l}\text { Problema } \\
\text { rotineiro } 3\end{array}$ & $\begin{array}{l}\text { Problema } \\
\text { não } \\
\text { rotineiro } 1\end{array}$ & $\begin{array}{l}\text { Problema } \\
\text { não } \\
\text { rotineiro } 2\end{array}$ & $\begin{array}{c}\text { Problema } \\
\text { não } \\
\text { rotineiro } 3\end{array}$ \\
\hline $\begin{array}{c}\text { Estruturou } \\
\mathrm{e}\end{array}$ & 6 & 1 & 0 & 1 & 1 & 0 \\
\hline Resolveu & & & & & & \\
\hline $\begin{array}{c}\text { Só } \\
\text { estruturou }\end{array}$ & 1 & 0 & 0 & 0 & 0 & 0 \\
\hline $\begin{array}{c}\text { Só } \\
\text { resolveu }\end{array}$ & 0 & 0 & 0 & 2 & 4 & 0 \\
\hline
\end{tabular}

Fonte: Elaborado pela pesquisadora

Para fins de esclarecimento da tabela apresentada acima, "só estruturou" significa que o aluno estruturou corretamente a regra de 3 relacionando as grandezas mas não conseguiu resolver a mesma. O "só resolveu" significa que o aluno não conseguiu estruturar a regra de 3 corretamente, mas conseguiu resolver a regra de 3 que propôs. Já o "estruturou e resolveu" o participante conseguiu montar e resolver corretamente, sendo que desses apenas 5 conseguiram obter o resultado final correto utilizando essa forma de resolução, sendo que as 5 foram resoluções do primeiro problema rotineiro.

Nem todos os alunos que resolveram a regra de 3 acertaram o resultado, pois apesar de terem montado corretamente a equação após uma multiplicação cruzada dos valores, operaram de forma inapropriada com os valores encontrados, especialmente por meio multiplicações e divisões.

Diante dos dados dessa tabela é possível observar que apesar de a maioria dos alunos ter demonstrado saber resolver o algoritmo da regra de 3 , poucos deles optaram por utilizá-la na resolução dos problemas propostos.

Podemos inferir desses dados que os alunos geralmente optam por realizar multiplicações e divisões para resolver problemas relacionados a razão e proporção em detrimento a regra de 3. Muniz (2009, p. 134) afirma que "os conceitos delineiam os procedimentos utilizados pelo aluno numa dada situação tanto quanto os procedimentos revelam o nível de desenvolvimento conceitual do aluno", então os 
conceitos que os alunos possuem e os procedimentos de resolução utilizados pelos mesmos para se resolver um problema estão intimamente ligados.

Dessa forma, pode-se observar que talvez os conceitos relacionados a regra de 3 não estejam bem consolidados junto a esses participantes. Vinte e dois dos 36 participantes, no exercício da primeira atividade individual, demonstraram conseguir resolver uma regra de 3 quando já está montada, mas para a resolução dos problemas a maior parte dos participantes optou por não utilizá-la, talvez por se sentirem inseguros em montá-la para posteriormente resolver.

No PISA 2015, a definição do letramento matemático está ligada as capacidades de "formular", "empregar" e "interpretar' a matemática. "Formular"

refere-se à capacidade de reconhecer e identificar oportunidades para utilizar a matemática $e$, posteriormente, fornecer uma estrutura matemática para um problema apresentado de maneira contextualizada. Determina-se de onde se pode extrair a matemática básica para analisar, estabelecer e resolver o problema.(BRASIL, 2016b, p. 141)

Dos processos matemáticos relacionados a formulação vale destacar alguns:

- Simplificar uma situação ou problema de maneira que seja tratável pela análise matemática

- Traduzir um problema em linguagem matemática ou em uma representação.

- Reconhecer aspectos de uma situação que corresponde a um problema, conceito, fato ou procedimento matemático conhecido."(BRASIL, 2016b, p. 141)

Pôde-se observar que os alunos participantes da pesquisa tiveram certa dificuldade com relação a esses processos, no sentido de definir a forma de resolução que seria utilizada para obter o resultado e "reescrever" o problema em uma forma matemática.

Com relação a essas capacidades, na avaliação do PISA de 2015 observou-se que a categoria "formular" configurou-se como a mais complexa para os estudantes de todos os países participantes do exame. Os dados encontrados nessa pesquisa, indicando que os alunos apresentam um desempenho melhor na resolução de uma regra de 3 já estruturada se assemelha a um dado obtido no PISA (BRASIL, 2016b, p. 158), onde

o fato de os Deltas de "formular" terem sido de longe os mais elevados dentre os dos três processos, mostra que os estudantes têm dificuldade de identificar oportunidades para usar a matemática em situações-problema e depois providenciar a estrutura matemática necessária para formular esse problema contextualizado matematicamente, ou seja, a transformação e modelagem de uma 


\begin{abstract}
situação-problema para a linguagem matemática é algo que ainda não resulta elementar para os estudantes. Em relação aos índices de "empregar", não variaram tanto entre os estados brasileiros, mantendose entre 14,89 (Espírito Santo) e 16,54 (Maranhão). Esse processo indica quanto os estudantes são capazes de executar cálculos e manipulações, além de aplicar conceitos e fatos que os levarão à solução matemática de um problema já formulado matematicamente (diferente do processo "formular", no qual o problema não está formulado desse modo). Por fim, na categoria de processo "interpretar", que indica quão eficazmente os estudantes refletem sobre soluções e conclusões matemáticas e interpretam-nas em um contexto real, o nível de dificuldade nas unidades da Federação brasileiras foi, em geral, de 14 pontos, menor que as outras duas em todos os casos. Nos países desenvolvidos estudados, o índice ficou bem abaixo da média de 13, o que revela ser esse um processo mais acessível e realmente assimilado pelos estudantes desses países do que pelos brasileiros.
\end{abstract}

Vale destacar que o verbo "interpretar" refere-se a refletir sobre os resultados e soluções encontrados e interpretá-los no contexto do problema. Nessa ótica, a presente pesquisa destaca essa habilidade no sentido de criticidade do sujeito com relação ao resultado da questão em foco. Mas também há de se considerar a questão da interpretação da questão, tendo uma compreensão inicial do contexto do problema. Para a OCDE, essa interpretação inicial estaria relacionada ao verbo "formular". Sendo assim, pode-se perceber que os participantes da pesquisa também conseguiam obter mais sucesso na resolução de exercícios, que requerem especialmente a habilidade de "empregar", e mais dificuldade na resolução dos problemas que requerem habilidades de "formulação".

Esse dado pode ser corroborado ao se observar a dificuldade dos participantes em modelar os problemas propostos por meio da linguagem matemática. Muitos não conseguiam traduzir o problema para uma representação matemática, realizando operações quase que aleatoriamente, sem analisar de uma forma mais específica o que o enunciado estava propondo.

Como evidenciado por meio das resoluções dos alunos, a maior parte dos equívocos parece estar relacionada a não compreensão do contexto e/ou dificuldades para modelar o procedimento matemático a ser realizado. Eles não conseguiram significar a situação e transformar em algo que pudesse ser resolvido utilizando conhecimentos matemáticos.

Com relação aos erros observados, pode-se destacar dificuldades na interpretação e modelagem do problema, falta de estratégia e dificuldade em realizar cálculos que envolvam as 4 operações básicas. 
Pelo fato de poucos alunos terem acertado os problemas não rotineiros, não foi possível estabelecer uma relação entre as formas de resolução propostas pelos participantes, comparado com o desempenho na resolução de problemas rotineiros.

\subsection{Sobre a motivação em matemática dos participantes}

Apesar da motivação em matemática não ser o objetivo principal da presente pesquisa, a mesma pode influenciar na relação do sujeito com a matemática e por consequência afetar o processo de resolução de problemas. Dessa forma, serão apresentadas algumas considerações referentes às informações trazidas no inventário.

$\mathrm{Na}$ questão 3 do inventário, foi solicitado aos alunos que completassem a frase "Minhas habilidades em matemática são...", para a análise dessa frase, as respostas foram categorizadas em 3 grandes grupos, baixa habilidade, média habilidade e alta habilidade, de acordo com o complemento da referida frase e demais informações obtidas no questionário, podendo ser assim distribuídos:

Tabela 8: Autodefinição das habilidades em matemática dos participantes

\begin{tabular}{ccc}
\hline Baixas & Medianas & Altas \\
\hline 14 & 17 & 5 \\
\hline
\end{tabular}

Fonte: Elaborado pela pesquisadora

As respostas que foram categorizadas com altas habilidades utilizaram palavras como altas ou muito boas, os com médias habilidades geralmente utilizaram as palavras normais, boas ou razoáveis, já as que foram classificadas como baixas habilidades utilizaram poucas, ruins ou outras que demonstrassem um baixo rendimento.

A questão 8, especificamente, tratava sobre a motivação em matemática sendo solicitado que completassem a frase "Minha motivação para fazer matemática é...". A análise foi feita de forma semelhante à questão 3 , obtendo a seguinte tabela: 
Tabela 9: Autodefinição da motivação em matemática dos participantes

\begin{tabular}{ccc}
\hline Baixas & Medianas & Altas \\
\hline 20 & 11 & 5 \\
\hline
\end{tabular}

Fonte: Elaborado pela pesquisadora

Das 20 respostas que foram classificadas como baixa motivação, 14 delas continham palavras como nula, zero, nenhuma ou nada. Esse grupo corresponde a aproximadamente $55,56 \%$ das respostas.

Ao comparar os participantes de cada categoria das tabelas 8 e 9 , foi possível perceber que em 24 casos as respostas foram classificadas na mesma categoria em ambas tabelas, ou seja, se o aluno declarava alta capacidade demonstrava também uma alta motivação, se o aluno declarava uma baixa capacidade também indicava uma baixa motivação, sugerindo uma relação direta entre essas variáveis.

Segundo Chacón (2003, p. 20), "as crenças matemáticas são um dos componentes do conhecimento subjetivo implícito do indivíduo sobre a matemática, seu ensino e sua aprendizagem". Cada aluno tem uma relação com a matemática, que foi desenvolvida/construída ao longo de sua vida, tanto dentro quanto fora do ambiente escolar e essa relação pode ser um fator a facilitar ou dificultar o seu processo de aprendizagem, podendo motivá-lo ou desmotivá-lo frente a atividades relacionadas a essa área.

Registros de expressões de desmotivação puderam ser encontrados em alguns protocolos das atividades que foram desenvolvidas, apresentando desenhos de rostos tristes ou corações partidos.

Figura 64: Produção escrita E1210.

Fonte: Arquivo pessoal da pesquisadora

Além da falta de motivação, também é possível perceber demonstrações de insegurança em relação ao procedimento matemático utilizado. Um aluno registrou no 
campo dos comentários que "é um pouco de lógica, mas deve estar errada" (E1304) ou ainda "foi assim que fiz, espero que esteja certo" (E1230). Nesses casos especificamente, as questões realmente estavam incorretas.

Mattos (2012) acrescenta:

Ao encontrar um obstáculo, na busca e na descoberta da solução do problema proposto, o educando torna-se inseguro, incapaz de resolver a situação, ele desenvolve atitudes de defesa, tornando-se avesso a disciplina, que acaba sendo o "bicho-papão" no índice de reprovação dos educandos (MATTOS, 2012, p. 98).

O que também pode ser percebido é que alguns dos alunos começaram a resolução, tendo se deparado no meio do caminho com algum obstáculo que não sabiam como contornar e findavam por desistir da resolução. Esse caso pode ser exemplificado por meio do protocolo do aluno 23 , apresentado a seguir.

Figura 65: Produção escrita E1223.
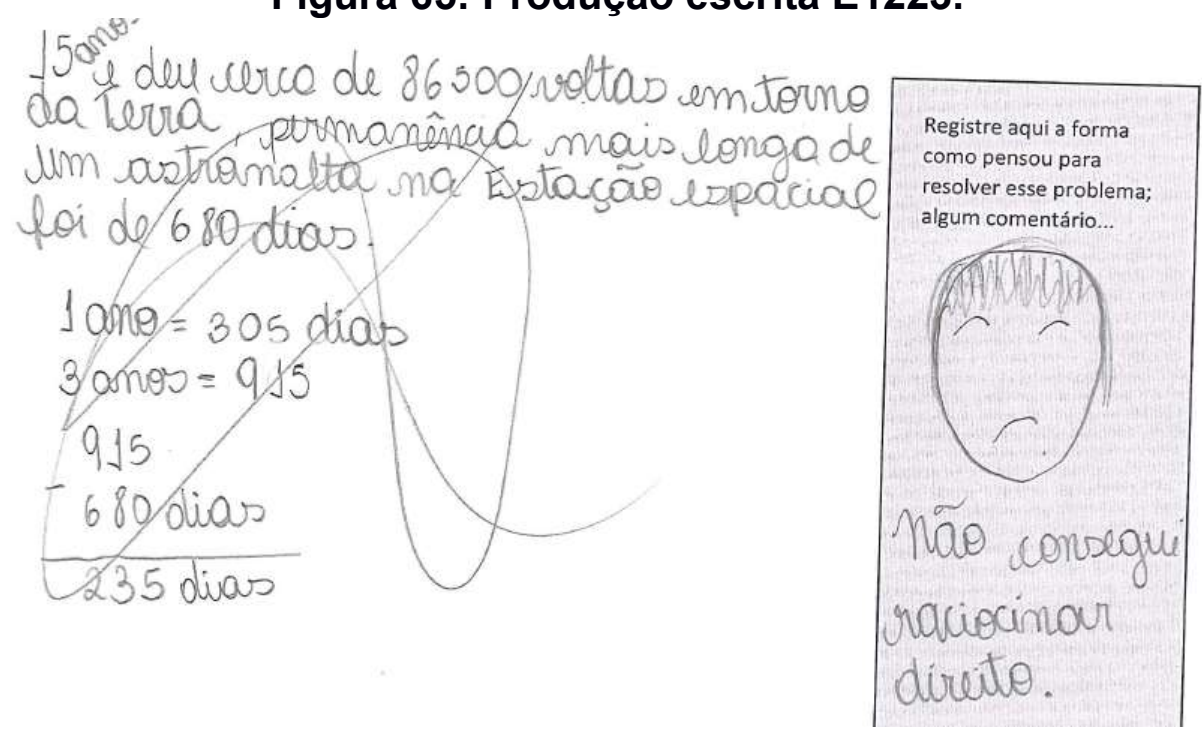

Fonte: Arquivo pessoal da pesquisadora

Como no caso da tentativa de resolução exemplificada na figura 65 , bem como em outros protocolos já destacados, pôde-se perceber que alguns participantes não tinham uma estratégia bem definida para a resolução do problema, ou seja, não tinham elaborado um plano de execução para a resolução. Nesse caso, o participante desistiu de resolver o problema rabiscando por cima da resolução que havia iniciado, demonstrando que a mesma não estava correta. Ao analisar o inventário "Minhas atitudes em relação a matemática", preenchido por esse aluno, identificou-se o 
registro de expressões que revelam uma baixa motivação com relação às atividades relacionadas à matemática.

Outras demonstrações de falta de motivação também foram registradas pelos alunos na segunda atividade individual. Um exemplo refere-se ao aluno 28 , que tentou resolver mas registrou um comentário dizendo "não sei, questões da OBMEP é difícil" (E2328) já demonstrando uma certa resistência a resolver problemas oriundos das Olimpíadas Brasileiras de Matemática para Escolas Públicas. Talvez ele tivesse as habilidades requeridas para resolver o problema, mas, por saber que a OBMEP apresenta situações um pouco mais complexas que as presentes no cotidiano escolar, não se envolveu com a tarefa proposta. Será que se essa questão fosse aplicada sem o rótulo OBMEP, haveria diferenças significativas nos resultados colhidos? Uma reflexão que nutre perspectivas para demais investigações.

O observador do grupo $\mathrm{H}$ faz uma reflexão interessante referente ao processo de resolução do grupo:

Figura 66: Produção escrita encontrada no relato do observador do grupo $\mathbf{H}$.

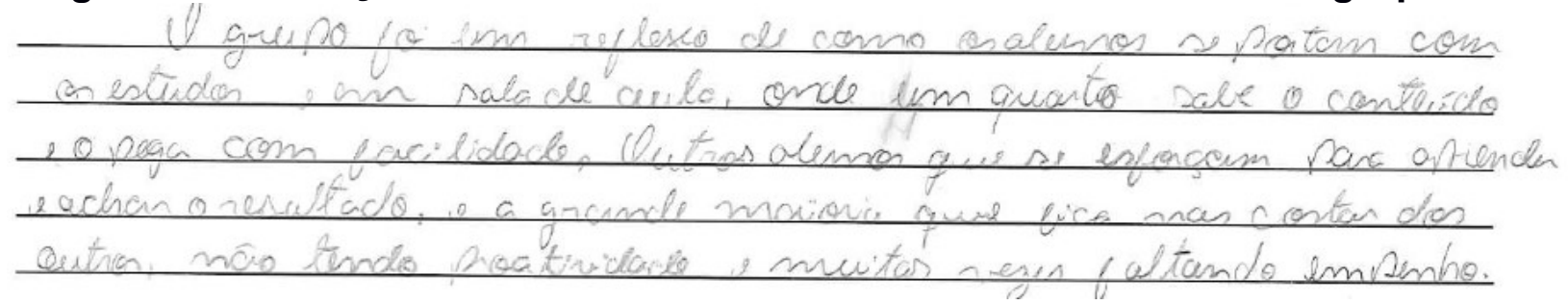

Fonte: Arquivo pessoal da pesquisadora

Vale destacar essa percepção do observador ao dividir a turma nos alunos que sabem matemática, os que não sabem muito mas se esforçam e se dedicam para aprender e os que não sabem e não têm interesse para o aprendizado relacionado a matemática.

A seguir, as atitudes desses participantes com relação ao que eles acham sobre suas capacidades com relação a matemática:

Figura 67: Produção escrita encontrada no inventário do participante 29. 3. Minhas capacidades em Matemática são considerades elevodas, mas nầ sāo diferentes das demais pessous, só tento me esforgar 
Fonte: Arquivo pessoal da pesquisadora

Figura 68: Produção escrita encontrada no inventário do participante 27. 3. Minhas capacidades em Matemática são Beas, dependendo do mers interesse

Fonte: Arquivo pessoal da pesquisadora

Figura 69: Produção escrita encontrada no inventário do participante 35.

3. Minhas capacidades em Matemática são

Fonte: Arquivo pessoal da pesquisadora

Figura 70: Produção escrita encontrada no inventário do participante 09.

3. Minhas capacidades em Matemática são uma decoudencia

Fonte: Arquivo pessoal da pesquisadora

O participante que o observador se referiu como o que "sabe o conteúdo" (29) teve uma demonstração de atitudes mais positivas do que os demais participantes do grupo, já o que "se esforça" relatou que suas capacidades são boas de acordo com seu interesse, sendo que os dois participantes que "fica nas costas dos outros" demostraram uma grande dificuldade com relação ao aprendizado de matemática indo ao encontro das considerações registradas pelo observador.

O participante 29 teve o maior número de acertos nas atividades individuais comparado aos demais participantes do grupo, ele não participou da primeira e na segunda atividade ele acertou 4 e teve um acerto parcial; o 27 acertou 2 questões e uma parcialmente na primeira atividade e apenas um acerto parcial na segunda atividade; o 35 teve um acerto na primeira atividade e um acerto parcial na segunda atividade.

Já o participante 09, nas duas atividades individuais, respondeu apenas 2 problemas e não apresentou soluções corretas para ambos, e deixou os demais em branco. Não responder aos problemas pode estar relacionado à baixa motivação em relação à matemática, manifestada explicitamente no inventário, no qual declarou 
achar tudo difícil e complicado. Possivelmente, a baixa motivação afetou diretamente em seu processo de resolução de problemas.

Se formos comparar o rendimento desses participantes nas atividades individuais, pode-se perceber que quanto melhor a relação do sujeito com a área de conhecimento a ser trabalhada melhor o desempenho do mesmo. Esses dados também corroboram a relação entre a motivação em matemática e a capacidade em matemática.

Chacón (2003, p. 24), por sua vez, pontua que:

Se o objetivo é melhorar o ensino e a aprendizagem da matemática, parece conveniente levar em conta os fatores afetivos dos alunos e dos professores. As emoções, atitudes e crenças atuam como forças impulsionadoras da atividade matemática. Em muitos casos atuam como forças de resistência à mudança.

Diante da relação entre a dimensão emocional e o processo de aprendizagem, além do inventário sobre "Minhas atitudes em relação a matemática" foi questionado ao observador se ele tinha percebido manifestação de alguma espécie de sentimento durante o processo de resolução na atividade em grupo. Um observador destacou que os membros do grupo se mantiveram calmos (grupo A), 2 (grupos $B$ e $H$ ) não identificaram a manifestação de algum sentimento específico, enquanto 5 (grupos C, $D, E, F$ e G) registraram que o grupo demonstrou algum tipo de sentimento negativo, como frustração, desânimo, revolta ou raiva por não conseguir resolver os problemas, conforme se depreende do registro escrito colhido apresentado a seguir:

\section{Figura 71: Produção escrita encontrada no relato do observador do grupo C.}

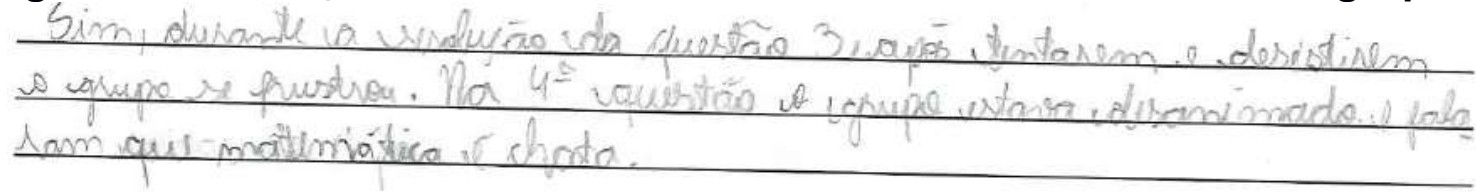

Fonte: Arquivo pessoal da pesquisadora

Ao analisar o inventário dos participantes deste grupo (C), pode-se perceber que eles descreveram suas habilidades como "mais ou menos" (I0316), "super baixas" (10321) e "ruins" (10336), evidenciando uma baixa motivação com relação a matemática. Vale a pena destacar que esse grupo foi o único que não acertou nenhuma questão. 
Um participante de outro grupo registrou em seu inventário que "Minha motivação para fazer matemática é ver a solução resolvida corretamente" (10824), registrando que se sente motivada ao acertar a questão, dessa forma vale levantar um questionamento: e se esse participante errasse a questão? Se sentiria desmotivado?

Diante disso é possível inferir um ciclo de aversão à matemática- o aluno não consegue resolver a questão, podendo ficar desmotivado, o que possivelmente gera impacto no processo de resolução das demais questões, não conseguindo resolver novas questões, ficando mais desmotivado, e assim por diante, ao que permite hipotetizar que o sujeito fique com certa aversão à matemática, desenvolvendo atitudes negativas em relação a essa área do conhecimento.

Figura 72: Ciclo de aversão à matemática
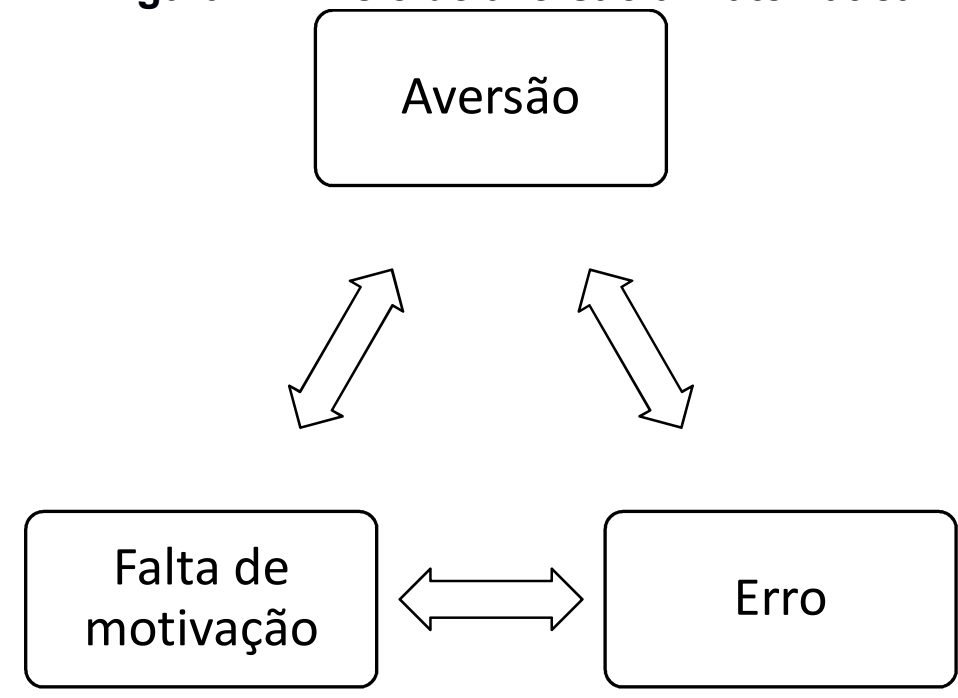

Fonte: Elaborado pela pesquisadora

Há de se considerar que podem existir diversos outros fatores que influenciam para a aversão do aluno com relação à matemática, mas, diante dos dados analisados, optou-se por destacar esse. Dessa forma, se um aluno não tem uma boa relação com a matemática, ele poderá ter resistência para se envolver em atividades relacionadas a essa área.

$\mathrm{O}$ observador do grupo $\mathrm{F}$ registrou que um participante disse ao iniciar a atividade de resolução dos problemas em grupo: "(um participante do grupo) disse que não sabe resolver nada" (OP2F), indicando que esse participante já afirmou não 
saber resolver os problemas propostos, embora no decorrer da atividade o observador registrou que apesar dessa afirmativa, durante o processo de resolução, foi notado que esse sujeito estava participando e dando opiniões.

Figura 73: Produção escrita encontrada no relato do observador do grupo $F$.

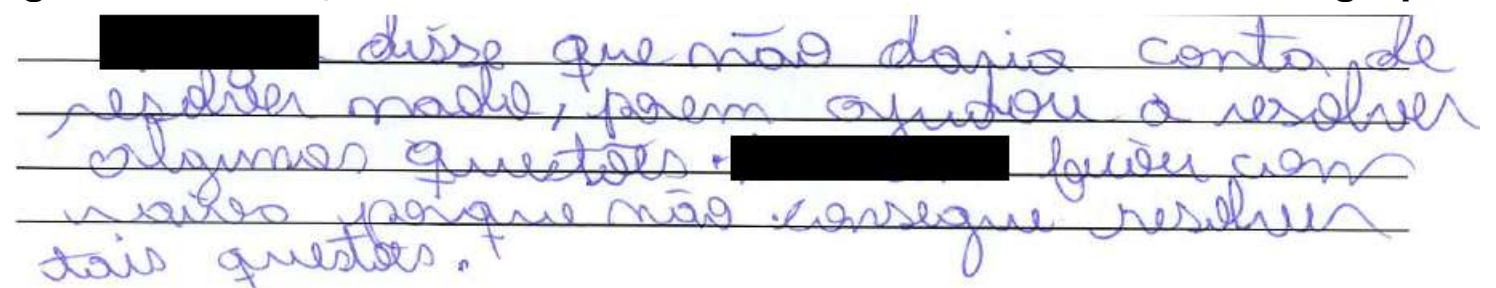

Isso mostra que mesmo que o aluno julgue possuir grandes fragilidades em suas habilidades matemáticas, ele tem sua forma de tentar resolver o problema e contribuir de alguma maneira, visando ajudar o grupo no processo de resolução. No inventário "Minhas atitudes com relação a matemática", esse sujeito demonstrou uma atitude bastante negativa com relação a matemática utilizando palavras de baixo calão ao completar a frase "Matemática é...", registrando em seu inventário exatamente o que o observador notou.

Figura 74: Produção escrita encontrada no inventário do participante 40.

\section{A Matemática é}

Fonte: Arquivo pessoal da pesquisadora

Nas atividades individuais o participante apresentou um baixo rendimento, acertando apenas uma questão da primeira atividade e nenhuma da segunda. Vale destacar que apesar da baixa motivação e acreditar que "não sabe nada", demonstrou interesse tentado resolver as questões propostas, não deixando nenhuma em branco.

Por fim, é possível destacar que um autoconceito positivo em relação à matemática, em geral, é expresso por aqueles que melhor se relacionam com essa área de saber, o que induz compreender que apreendem conceitos matemáticos com maior facilidade do que aqueles que de antemão, em vista de um autoconceito negativo, passam a acreditar não serem capazes de compreender situações matemáticas, tampouco em resolver problemas. O processo de ensino-aprendizagem 
da matemática parece ter que atuar com o ensino de conceitos tanto quanto com o estímulo motivacional dos estudantes, de modo a propiciar uma somática de elementos favoráveis para o sucesso no aprendizado em matemática, revertendo o insatisfatório quadro brasileiro nessa área de saber. 


\section{CONSIDERAÇÕES}

Em pesquisas na educação, mais do que resultados exatos e inferências generalistas, é importante considerar a relação do processo de ensino-aprendizagem de certo grupo por se configurar uma amostra do que pode ocorrer em situações maiores, de modo a ampliar o arcabouço de conhecimento acerca das variadas inquietudes relacionadas à dinâmica de ensino-aprendizagem. E, assim entende-se fora desenvolvido este trabalho, com vistas a compreender melhor o fenômeno ligado à resolução de problemas matemáticos de razão e proporção por alunos concluintes da educação básica.

Diante de tudo que foi discorrido ao longo deste trabalho, percebe-se algumas recorrências que foram observadas acerca da forma de resolução de problemas por parte dos estudantes partícipes da pesquisa, as quais vale destacar: falta de organização dos dados, equívocos na realização de algumas operações básicas da aritmética, falta de criticidade nas repostas, dificuldade de interpretação, realização de contas aleatórias, demonstração de desmotivação e dificuldade na estruturação do algoritmo da regra de 3 .

Ressalte-se que tais fragilidades foram encontradas em estudantes concluintes da educação básica, não adentrando sequer em problemas que envolvessem grandezas inversamente proporcionais ou que exigissem o cálculo de regra de três composta.

Há de se considerar que a pesquisa foi realizada com alunos concluintes do ensino médio, e alguns problemas tinham contextos mais simplificados onde era esperado que os alunos obtivessem mais sucesso na resolução. Esses dados nos levam a questionar sobre o aprendizado dos alunos na área de matemática, principalmente no que tange a resolução de problemas, no qual foi possível perceber que quanto maior a necessidade de interpretação e modelagem para se resolver o problema, menor o índice de acerto.

Dessa forma surge alguns questionamentos para reflexão: Quais são as habilidades relacionadas a matemática desenvolvidas por esses alunos ao longo de sua vida escolar na educação básica? Da forma como está ocorrendo o processo ensino-aprendizagem está obtendo sucesso? Aparentemente não. Isso reforça as estatísticas oficiais que demonstram o quão o aprendizado sobre matemática no Brasil 
encontra-se à margem do esperado, em especial no que se refere a uma educação pública de qualidade nessa área de saber.

A partir de dinâmica similar ao proposto nessa pesquisa é possível conhecer como os estudantes internalizam certos conceitos, bem como as maneiras que utilizam para resolver problemas. Isso facilita a proposição de uma intervenção mais pontual junto aos mesmos, buscando um melhor aprendizado. Com esses dados é possível ao docente planejar estratégias para que os alunos possam amadurecer o conhecimento que já possuem desenvolvendo, junto aos mesmos, formas de resolução mais efetivas para resolver os problemas.

No caso da turma participante da pesquisa, ao se analisar as resoluções das questões propostas pode-se observar que os alunos não tinham consolidado a utilização de regra de três para a resolução de problemas, não relacionando devidamente as grandezas.

O problema rotineiro proposto para a primeira atividade é um exemplo comum de problema relacionado a razão e proporção, tipicamente resolvido por regra de 3 . No entanto, apenas 7, dos 32 alunos que tentaram resolver esse problema, recorreram a esse algoritmo. Esse foi o problema que obteve maior índice de tentativas de resolução utilizando a regra de 3, conforme apresentado na tabela 4

Nessa ótica, a pouca utilização do procedimento da regra de 3 para a resolução de problemas, que tipicamente poderiam ser resolvidos utilizando esse recurso, pode demonstrar certa insegurança dos participantes com relação ao desenvolvimento desse procedimento, corroborado pelo fato que parte dos que tentaram resolver utilizando a regra de 3 não conseguiram relacionar corretamente as grandezas envolvidas no problema. Ou mais, tal fato pode representar que esses estudantes não adquiriram a habilidade de transpor esse procedimento operatório para a resolução de diferentes problemas.

Os resultados encontrados nessa pesquisa não se aproximam dos dados apresentados por Obando, Vasco e Arboleda (2014), como apresentado no Capítulo 2, no qual destacavam que em um estudo realizado na Colômbia os estudantes geralmente utilizavam regra de 3 para resolver problemas relacionados a razão e proporção. Em grande parte da dinâmica de resolução, dissertada neste trabalho, os alunos não utilizaram de tal estratégia para resolver os problemas. Embora grande parte (22 de 36 alunos) dos participantes acertou a resolução do primeiro exercício a 
partir da aplicação da propriedade fundamental das proporções, o mesmo fato não se concretizou quando diante de problemas onde se era esperado que estruturassem a regra de 3.

É interessante destacar esse fator ao se comparar os dois países, onde um aplicou-se em demasia e o outro tenha uma utilização bem menos expressiva da utilização desse procedimento operatório. Umas das possíveis justificativas para esse dado pode ser a insegurança dos alunos na montagem e a correta associação das grandezas envolvidas na regra de 3 , o que em ambos os casos são reflexos de fragilidades conceituais quanto ao conceito de razão e proporção - objeto elementar de conhecimento matemático.

Diante dos problemas propostos, foi necessário que os alunos demonstrassem conhecimentos diversos para que obtivessem sucesso na resolução dos mesmos, pois para "propor solução, agir e refletir implica necessariamente a mobilização de conceitos disponíveis no repertório cognitivo" (Muniz, 2009, p. 119), sendo assim para se resolver um problema, o sujeito que se propõe a resolvê-lo mobiliza variados conceitos, uma vez que ao se deparar com uma situação complexa pode recorrer a diversos conhecimentos que possui articulando uma gama de conceitos.

Diante dessa certa insegurança com relação a regra de 3 , ou não percepção de que esse seria um algoritmo eficiente para a resolução do que lhes era proposto, os alunos que acertaram esses problemas mobilizaram outros conceitos, principalmente relacionados à multiplicação e divisão, para realizarem a resolução dos problemas propostos conseguindo assim desenvolver um raciocínio correto para a resolução dos problemas.

Considerando a análise dos dados, pode-se perceber que, em geral, um dos principais fatores que levaram ao insucesso do processo de resolução dos problemas propostos relaciona-se a dificuldade de interpretação. A falta da compreensão do que a questão está solicitando, bem como compreender a "história que a questão conta", pode não ter favorecido aos alunos traçar uma estratégia para resolver os problemas, pois compreender o problema e traçar uma estratégia para resolução do mesmo estão intimamente ligados, tendo em vista que pode ser um fator de dificuldade elaborar uma estratégia para a resolução de um problema quando não se apreende com sucesso a essência de seu contexto, ou seja, não havendo essa compreensão do problema não há estratégia de resolução a delinear/traçar, o que em muito pode ter 
sido o fato gerador da série de operações aleatórias propostas por muitos dos estudantes partícipes do estudo.

$\mathrm{Na}$ questão 3 da atividade em grupo, cada um dos 8 grupos teve uma resposta diferente, ou seja, apesar do item ser o mesmo para todos, as formas de interpretação e de utilização dos dados foram bastante diversas. Essa diversidade de resoluções e respostas nas questões, pode ser observada principalmente nas produções dos alunos que não obtiveram o resultado esperado, sendo que, de uma forma geral, as respostas foram bastantes variadas. No entanto, com relação as questões que estavam corretas houve pouca variação nas formas de resolução, podendo ser organizadas em poucas categorias diferentes, sendo possível observar certa padronização nessas produções, em especial nas resoluções dos exercícios.

Ao realizar a análise das resoluções dos alunos pode-se perceber a importância da oferta de feedback, pois os equívocos cometidos por alguns deles podem ser evitados caso o professor proponha ajudá-los questionando acerca dos motivos de se ter praticado uma ou outra estratégia que tenha conduzido a uma resposta diversa da esperada, levando-o a reflexão sobre seus equívocos evitando que o mesmo erro ocorra novamente. No que se refere à dinâmica relatada nessa pesquisa, após a prática do feedback percebeu-se que alguns participantes passaram a utilizar de algum tipo desenho, ilustrações, tabelas entre outros para representar a situação relacionada ao problema alvo para auxiliar na interpretação.

Outra percepção que pode ser destacada é com relação ao desenvolvimento da atividade de resolução de problemas em grupos, no qual notou-se que não basta apenas propor este tipo de organização para que eles possam efetivamente e ativamente trabalhar de forma coletiva e colaborativa. A atividade em grupo proposta visava uma interação entre os pares, para que pudessem debater sobre as possibilidades de resoluções das questões estimulando a troca de experiências, bem como desenvolver competências e habilidades relacionadas ao trabalho em equipe, como saber administrar conflitos, respeitar a opinião do próximo, desenvolver proatividade e espírito de liderança, contudo, pode-se perceber que em algumas questões alguns alunos resolviam quase que individualmente o problema, não havendo dessa forma a troca de ideias com seus pares, bem como a desmotivação de outros participantes que não estavam muito animados em participar da atividade. 
Diante dessa percepção, vale questionar sobre como criar um ambiente estimulador para o trabalho em grupo, onde os integrantes possam mutuamente se ajudar nos processos de resolução trocando ideias e experiências. Talvez seja válido considerar o papel do docente em atuação como mediador e orientador com vistas a estimular essa interação entre os participantes dos grupos.

No capítulo 2, ao se definir o conceito de problema, foi destacado dois elementos comuns em diversos conceitos: não saber resolver de imediato e ter o interesse em resolvê-lo. Pode-se se perceber que a maioria dos alunos se enquadravam no primeiro requisito relacionado a não saber como resolvê-lo imediatamente, mas foi observado também grande desmotivação por parte dos alunos com relação a matemática, bem como desmotivação de alguns participantes para o desenvolvimento das atividades propostas.

Uma das limitações que pode ser verificada na pesquisa tange a escolha das questões, tendo em vista que deveriam ser atividades que estivessem em um grau de dificuldade adequado ao nível de escolarização daqueles estudantes. Pode-se perceber que o segundo problema rotineiro selecionado foi muito difícil para os participantes, no qual apenas 9 dos 31 alunos acertaram a resolução. Ao selecionar esse problema pensou-se que alunos concluintes do ensino médio não teriam dificuldade em demasia para resolvê-lo, contudo, dessa forma optou-se por selecionar um problema um pouco mais simples a ser resolvido na atividade em grupo. Essa pode ser uma limitação da pesquisa ao se considerar que poderia ter sido trocada a ordem de aplicação desses dois problemas, ou até mesmo replicar o problema da segunda atividade individual para ser resolvido novamente em grupo para se comparar as formas de resoluções individuais e em grupo observando se eles obteriam mais sucesso nessas resoluções.

Outro fator a ser levantado é com relação as alternativas da segunda questão rotineira que podem ter cerceado a diversificação das respostas encontradas pelos alunos ou ainda induzido alguns a algum resultado.

Independente da classificação do problema o importante são as possibilidades de resolução que o mesmo oferta: é muito fácil para o aluno? Leva o aluno a pensar para resolver ou já resolve quase diretamente? Nas questões em evidência, os alunos tiveram dificuldade em quase todos os problemas. Pode-se perceber que os 
problemas não rotineiros tiveram uma taxa de acerto ainda menor do que a dos problemas rotineiros.

Muitos dos estudantes demonstram uma grande ojeriza à essa área de saber. Isso leva a questionar as razões de grande parte dos alunos demonstrarem essa aversão ao conhecimento matemático. O tamanho sentimento de desgosto e frustração faz com que muitos já estabeleçam uma resistência em atividades relacionadas a matemática ou ainda sequer tentem resolvê-las quando são propostas. Assim, restam outras indagações: Uma metodologia de ensino baseada na resolução de problemas pode tornar o aprendizado mais significativo e interessante para o estudante? Como podemos utilizar essas estratégias de feedback em sala de aula considerando a realidade atual, sendo que em uma mesma sala de aula podem haver diversos perfis de estudantes, um currículo extenso e por vezes pouco significativo para os alunos, pouco tempo de aula, dentre outros fatores. Tais questionamentos ainda podem suscitar nos sujeitos que estão relacionados, direta ou indiretamente, a área educacional a constante reflexão, principalmente aos professores, que sendo aqueles que atuam diretamente em sala de aula junto aos alunos possam rever criticamente suas práticas pedagógicas.

Ao finalizar essa pesquisa, em particular, fico com a sensação que hoje tenho mais perguntas do que respostas: como eu, no meu papel de docente, posso auxiliar os alunos a desenvolverem seu conhecimento na área de matemática? A resposta não é única e geral para todos, porém as perguntas não são tão importantes quanto as respostas? Mas, em uma coisa acredito: que mudança para uma educação melhor pode começar aos poucos, por nós, em nossas próprias aulas... 


\section{REFERÊNCIAS}

Alves-Mazzotti, M.J. Usos e abusos do estudo de caso. Cadernos de Pesquisa, 2006.

BARDIN, L. Análise de conteúdo. 3 ed. Lisboa: Edição 70 Ltda., 2004.

BRANCA, N. A. Resolução de problemas como meta, processo e habilidades básicas. In: KRULIK, Stephen; REYS, Robert E. (Org.). A resolução de problemas na matemática escolar. São Paulo: Atual, 1997.

BRASIL, Secretaria de Educação Fundamental. Parâmetros curriculares nacionais: matemática. Brasília: MEC/SEF, 1997.

BRASIL, Ministério da Educação. Secretaria da Educação Média e Tecnológica. Parâmetros Curriculares Nacionais para o Ensino Médio. Brasília: MEC/SEMT, 2000.

BRASIL, Instituto Nacional de Estudos e Pesquisas Anísio Teixeira. Sistema de Avaliação da Educação Brasileira - Edição 2015 Resultados. Brasília: INEP, 2016a. Disponível em: < http://download.inep.gov.br/educacao_basica/prova_brasil_saeb/resultados/2015/res umo_dos_resultados_saeb_2015.pdf>. Acesso em: 20 dez. 2016.

BRASIL, Instituto Nacional de Estudos e Pesquisas Anísio Teixeira. Brasil no PISA 2015 : análises e reflexões sobre o desempenho dos estudantes brasileiros I OCDE-Organização para a Cooperação e Desenvolvimento Econômico. São Paulo: Fundação Santillana, 2016b. Disponível em: <http://download.inep.gov.br/acoes_internacionais/pisa/resultados/2015/pisa2015_co mpleto_final_baixa.pdf> Acesso em: 20 dez. 2016.

BROOKHART, Susan M. How to give effective feedback to your students. Alexandria: Association for Supervision and Curriculum Development, 2008.

BURIASCO, R. L. C.. CIANI, A. B. Para falar em erro: Um mosaico. In CURY, H. N. Erros na aprendizagem de Matemática: Relatos de Pesquisas e Reflexões. Santa Maria: Centro Universitário Franciscano, 2016.

CHACÓN, I. M. G. Matemática Emocional: Os Afetos na Aprendizagem Matemática. Porto Alegre: Artmed, 2003.

CRESWELL, J. W. Projeto de pesquisa: métodos qualitativo, quantitativo e misto. $3^{\circ}$ Ed. Porto Alegre: Artmed, 2010. 
CURY, H. N. Análise de erros: o que podemos aprender com as respostas dos alunos. Belo Horizonte: Autêntica, 2008.

DALTO, J. O; BURIASCO, R. L. C. Problema proposto ou problema resolvido: qual a diferença? Educação e Pesquisa, São Paulo, v.35, n.3, p. 449-461, set./dez, 2009.

DANTE, L. R. Formulação e resolução de problemas de matemática. Teoria e prática. São Paulo: Ática, 2009.

DENZIN, N. K.; LINCOLN, Y. S. O Planejamento da Pesquisa Qualitativa: Teorias e abordagens. 2a. Ed. Porto Alegre: Artmed, 2006.

DINIZ, M. I. Resolução de problemas e comunicação. In: SMOLE, K. C. S.; DINIZ, M. I. (Org.). Ler, escrever e resolver problemas: habilidades básicas para aprender matemática. Porto Alegre: Artmed, 2001.

DURAN, David; VIDAL, Vinyet. Tutoría entre iguales: de la teoría a la práctica. Barcelona: Editorial Graó, 2011.

ELIA, I.; VAN DE HEUVEL-PANHUIZEN, M.; KOLOVOU, A. Exploring strategy use and strategy flexibility in non-routine problem solving by primary school high achievers in Mathematics. ZDM - The International Journal on Mathematics Education, n. 41, 2009.

FÁVERO, M. H. Introdução. In: FÁVERO, M. H.; CUNHA, C (Org). Psicologia do conhecimento: o diálogo entre as ciências e a cidadania. Brasília: UNESCO, Instituto de Psicologia da Universidade de Brasília, Liber Livro Editora, 2009.

FERREIRA, P. E. A.; BURIASCO, R. L. C. Educação matemática realística: uma abordagem para os processos de ensino e de aprendizagem. Educ. Matem. Pesq., São Paulo, v.18, n.1, 2016.

FERNANDES, D. Avaliar para aprender: fundamentos, práticas e políticas. São Paulo: Editora Unesp, 2009.

FIORENTINI, D.; LORENZATO S. Investigação em educação matemática, percursos teóricos e metodológicos. Campinas: Autores Associados, 2006.

FLICK, U. Uma Introdução à Pesquisa Qualitativa. $3^{a}$. Ed. Porto Alegre: Artmed, 2009.

GIL, A. C. Métodos e técnicas de Pesquisa Social. $6^{\circ}$ Ed. São Paulo: Editora Atlas, 2008.

GODOY, A. S. Introdução à pesquisa qualitativa e suas possibilidades. Revista de Administração de empresas, v. 35, n. 32, 1995. 
HARWELL, M. R. Research Design in Qualitative /Quantitative / MixedMethods. In: CONRAD, C. F.; SERLIN, R. C. The SAGE Handbook for Research in Education: Pursuing ideas as the keystone of exemplary inquiry. $2^{\text {a }}$ Edition. Thousand Oaks: SAGE Publications, 2011

JACCOUD, M.; MAYER, R. A observação direta e a pesquisa qualitativa. In: POUPART, J., et al. A pesquisa qualitativa: Enfoques epistemológicos e metodológicos. Petrópolis: Vozes, 2008.

LESTER Jr., F. K. Thoughts about research on mathematical problem-solving instruction. The Mathematics Enthusiast, Montana, vol. 10, n. 1 e 2, 2013.

MAYER, R. E. Mathematical problem solving. In ROYER, J. M., Mathematical Cognition.Greenwich. Info age Publishing, 2003.

MATTOS, S. M. N. O Desenvolvimento do Raciocínio Lógico-Matemático: Possíveis Articulações Afetivas. Caderno Dá Licença. Março - 2012 / Volume 7- Ano 10

MUNIZ, C. A. A produção de notações matemáticas e seu significado. In: FÁVERO, M. H.; CUNHA, C (Org). Psicologia do conhecimento: o diálogo entre as ciências e a cidadania. Brasília: UNESCO, Instituto de Psicologia da Universidade de Brasília, Liber Livro Editora, 2009.

KRIPKA, R. M. L.; BONOTTO, D. L.; RICHTER, L. Observação na Pesquisa Qualitativa: Contribuições e dificuldades em estudo de caso. Atas CIAIQ2015. Investigación Cualitativa em Educación, 2015.

OBANDO, Gilberto; VASCO, Carlos Eduardo y ARBOLEDA, Luis Carlos. Enseñanza y aprendizaje de la razón, la proporción y la proporcionalidad: un estado del arte. Relime [online]. 2014, vol.17, n.1

OECD/CERI. Assessment for Learning - FormativeAssessment. International Conference "Learning in the 21st Century:Research, Innovation and Policy”. OECD/CERI: Paris, 2008.

ONUCHIC, L.R. Ensino-aprendizagem de matemática através da resolução de problemas. In BICUDO, M. A. V. (org.). Pesquisas em Educação Matemática: Concepções e Perspectivas. São Paulo: Editora da UNESP, 1999.

ONICHIC, L. R.; ALLEVATO, M. S. G. Pesquisa em Resolução de Problemas: caminhos, avanços e novas perspectivas. Bolema, v. 25, n. 41, 2011.

POLYA, G. O ensino por meio de problemas. Revista do Professor de Matemática, SBM, n. 7, p. 11-16, 1985.

POLYA, G. A arte de resolver problemas: um novo aspecto do método matemático. Rio de janeiro: Interciência, 1994. 
STANCANELLI, R. Conhecendo diferentes tipos de problemas. In: SMOLE, K. C. S.; DINIZ, M. I. (Org.). Ler, escrever e resolver problemas: habilidades básicas para aprender matemática. Porto Alegre: Artmed, 2001.

STERNBERG, R. J. Psicologia cognitiva. São Paulo: Cengage Learning, 2010.

SCHOENFELD, A. H. Learning to think mathematically: Problem solving, metacognition, and sense-making in mathematics. In GROUWS, D. (Org.), Handbook for Research on Mathematics Teaching and Learning. New York: MacMillan, 1992.

SCHOENFELD, A. H. Problem solving in the United States, 1970-2008: research and theory, practice and politics. ZDM Mathematics Education, 2007a.

SCHOENFELD, A. H. What is Mathematical Proficiency and How Can It Be Assessed? Assessing Mathematical Proficiency, MSRI Publications, Volume 53, 2007b.

SCHOENFELD, A. H. Reflections on Problem Solving Theory and Practice. The Mathematics Enthusiast, Montana, vol. 10, n. 1 e 2, 2013.

SILVA, M. C. N. BURIASCO, R. L. C. Análise da produção escrita em matemática: algumas considerações. Ciência \& Educação, v. 11, n. 3, p. 499-512, 2005.

SILVA, E. B. O Diálogo entre diferentes sujeitos que aprendem e ensinam matemática no contexto escolar dos anos finais do ensino fundamental. Tese de Doutorado. Brasília: UnB, 2014

VALDÉS, E. A. El desarrollo de la creatividaden la Educación Matemática. Anais do Congresso Iberoamericano de Educación: Metas 2021 - Um congresso para que pensemos entre todos la educación que queremos. Buenos Aires, 2010.

WOODWARD, J., et al. Improving mathematical problem-solving in Grades 4 through 8: A practice guide. Washington, D.C.: National Center for Education Evaluation and Regional Assistance, Institute of Education Sciences, U.S. Department of Education, 2012. Disponível em: http://files.eric.ed.gov/fulltext/ED532215.pdf 


\section{APÊNDICE A}

\section{Termo de Consentimento Livre e Esclarecido}

Prezado(a) Senhor(a),

Gostaríamos de convidá-lo (a) a participar da pesquisa "ESTRATÉGIAS DE ESTUDANTES CONCLUINTES DA EDUCAÇÃO BÁSICA NA RESOLUÇÃO DE PROBLEMAS MATEMÁTICOS", realizada pelo Programa de Pós-graduação da Faculdade Educação da Universidade de Brasília - PPGE/FE/UnB.

O objetivo da pesquisa é analisar as estratégias de resolução de problemas rotineiros e não rotineiros de razão e proporção utilizadas por estudantes de $3^{\circ}$ ano do Ensino Médio de uma escola pública do Distrito Federal. A sua participação é muito importante e ela se dará através da participação em atividades de resolução de problemas.

Dessa forma, solicito que possam ser cedidos o direito de uso de imagem, gravações de áudio e vídeo, respostas de questionários e de entrevistas coletadas pela mestranda para o transcurso da pesquisa. Informamos ainda que o material obtido poderá ser utilizado em diversos tipos de pesquisa (em dissertação de mestrado, tese de doutoramento, comunicações em congressos e seminários e publicações de artigos ou periódicos) e será tratado com o mais absoluto sigilo e confidencialidade, de modo a preservar a identidade do participante.

Gostaria de esclarecer que sua participação é totalmente voluntária, sendo assim o sr. (a) não terá nenhum custo ou quaisquer compensações financeiras, the sendo permitido se recusar a participar, ou mesmo desistir a qualquer momento sem que isto acarrete qualquer ônus ou prejuízo à sua pessoa.

Diante do exposto, neste momento me coloco a sua disposição para the esclarecer informações que julgar necessárias relacionadas a esta pesquisa visando esclarecer as dúvidas referentes a sua participação nesta pesquisa. Eventuais esclarecimentos poderão ser feitos também por meio do e-mail juliana.4568@yahoo.com.br. 
O benefício relacionado à sua participação será de colaborar com o conhecimento científico para a área da educação matemática. Sua participação é muito importante.

Brasília, de de 2015.

\section{Pesquisadores Responsáveis:}

Mestranda Juliana Campos Sabino de Souza

Matrícula UnB: 150051000

Prof. Dr. Cleyton Hércules Gontijo

Matrícula UnB: 1.036 .041

Eu tendo sido devidamente esclarecido(a) sobre os procedimentos da pesquisa, e tendo recebido todas as informações que julguei necessárias dos pesquisadores responsáveis, concordo em participar voluntariamente da pesquisa descrita acima.

Assinatura (ou impressão dactiloscópica):

Data: 


\section{ANEXO A \\ "Minhas atitudes em relação a matemática"}

Prezados (as) Alunos (as),

Estamos desenvolvendo um estudo com o objetivo de identificar como os estudantes se relacionam com a Matemática. Como parte deste estudo, elaboramos um instrumento de pesquisa e gostaríamos de contar com a sua colaboração, respondendo com seriedade todos os itens abaixo.

Suas respostas serão tratadas de forma confidencial e os resultados serão apresentados de modo a não permitir a sua identificação.

Nome:

Considerando suas próprias atitudes em relação à Matemática, complete as frases com as palavras que melhor expressam os seus sentimentos:

1. Meus professores de Matemática da escola

2. A Matemática é

3. Minhas capacidades em Matemática são

4. Para ser bom em Matemática é necessário

5. Eu acho difícil em Matemática

6. Um bom professor de Matemática deveria

7. Poderia aprender mais Matemática se

8. Minha motivação para fazer Matemática é 
9. O melhor que um professor de Matemática pode fazer por mim é

10. Quando tenho aula de Matemática

11. Na escola, quando estava na aula de Matemática eu

12. Agora, quando estou na aula de Matemática eu

13. Gostava da aula de Matemática até que

14. Minha experiência mais positiva com a Matemática acontece quando

15. Minha experiência mais negativa com a Matemática acontece quando

16. Sinto que a Matemática faz "quebrar a cabeça" quando

17. Quando escuto a palavra Matemática eu

18. Quando escuto dizer que a Matemática é excelente eu

19. Quando aprendo Matemática, sinto-me

20. O que eu gostaria de dizer sobre a Matemática é 